\title{
Environmental Impacts of Options for Disposal of Depleted Uranium Tetrafluoride $\left(\mathrm{UF}_{4}\right)$
}

Environmental Assessment Division Argonne National Laboratory

Operated by The University of Chicago, under Contract W-31-109-Eng-38, for the

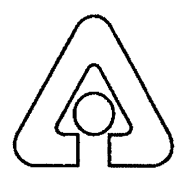

United States Department of Energy 


\section{Argonne National Laboratory}

Argonne National Laboratory, with facilities in the states of Illinois and Idaho, is owned by the United States Government and operated by The University of Chicago under the provisions of a contract with the Department of Energy.

This technical memorandum is a product of Argonne's Environmental Assessment Division (EAD). For information on the division's scientific and engineering activities, contact:

Director, Environmental Assessment Division

Argonne National Laboratory

Argonne, Illinois 60439-4832

Telephone (630) 252-3107

Presented in this technical memorandum are preliminary results of ongoing work or work that is more limited in scope and depth than that described in formal reports issued by the EAD.

Publishing support services were provided by Argonne's Information and Publishing Division (for more information, see IPD's home page: http://www.ipd.anl.gov/).

\section{Disclaimer}

This report was prepared as an account of work sponsored by an agency of the United States Government. Neither the United States Government nor any agency thereof, nor The University of Chicago, nor any of their employees or officers, makes any warranty, express or implied, or assumes any legal liability or responsibility for the accuracy, completeness, or usefulness of any information, apparatus, product, or process disclosed, or represents that its use would not infringe privately owned rights. Reference herein to any specific commercial product, process, or service by trade name, trademark, manufacturer, or otherwise does not necessarily constitute or imply its endorsement, recommendation, or favoring by the United States Government or any agency thereof. The views and opinions of document authors expressed herein do not necessarily state or reflect those of the United States Government or any agency thereof, Argonne National Laboratory, or The University of Chicago. 
Environmental Impacts of Options for Disposal of Depleted Uranium Tetrafluoride $\left(\mathrm{UF}_{4}\right)$

by F.A. Monette, T. Allison, ${ }^{*}$ H.I. Avci, B.M. Biwer, J.P. Butler, Y.-S. Chang, J.-J. Cheng, S.M. Folga, ${ }^{*}$ H.M. Hartmann, M.A. Lazaro, D.J. LePoire, D.A. Tomasko, R.A. Van Lonkhuyzen, and B.D. Wilkins

Environmental Assessment Division

Argonne National Laboratory, 9700 South Cass Avenue, Argonne, Illinois 60439

June 2001

Work sponsored by U.S. Department of Energy, Office of Environmental Management, and Office of Site Closure-Oak Ridge Office

* Allison and Folga are affiliated with Argonne's Decision and Information Sciences Division. 
This report is printed on recycled paper. 


\section{CONTENTS}

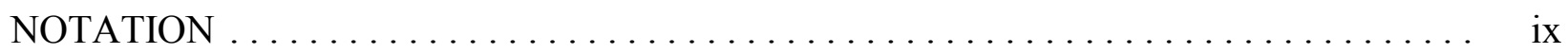

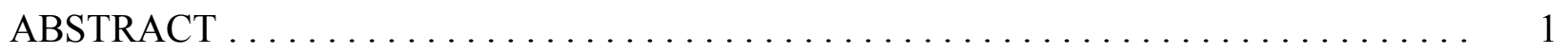

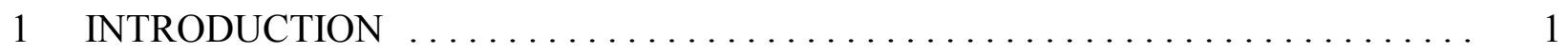

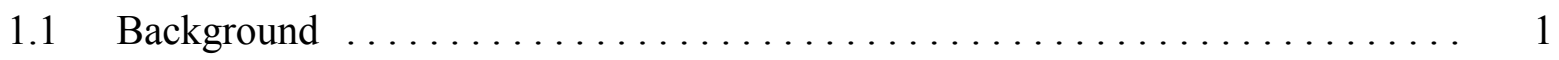

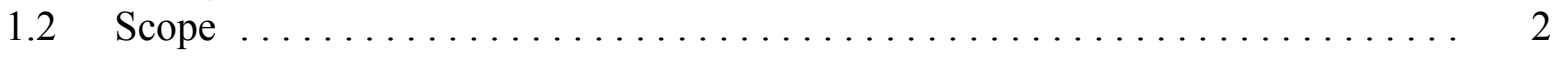

2 SUMMARY OF $\mathrm{UF}_{4}$ DISPOSAL IMPACTS $\ldots \ldots \ldots \ldots \ldots \ldots \ldots \ldots \ldots \ldots$

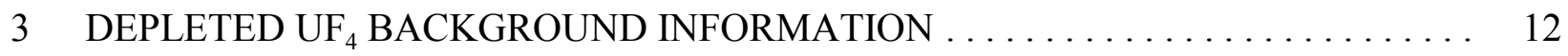

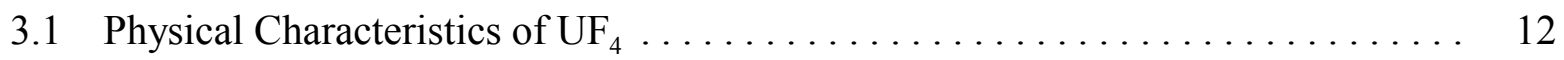

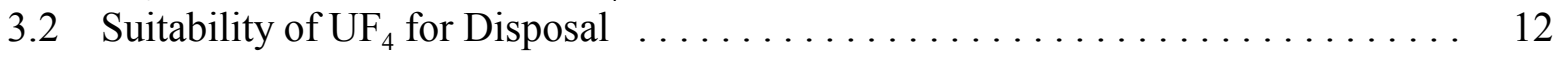

4 ASSESSMENT ASSUMPTIONS AND METHODOLOGY $\ldots \ldots \ldots \ldots \ldots \ldots \ldots$

5 DESCRIPTION OF DISPOSAL FACILITY OPTIONS $\ldots \ldots \ldots \ldots \ldots \ldots \ldots$

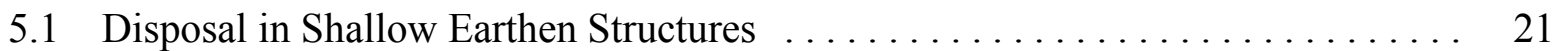

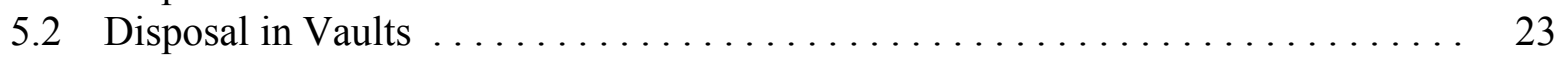

5.3 Disposal in a Mine ..................................... 24

6 IMPACTS OF OPTIONS — OPERATIONAL PHASE $\ldots \ldots \ldots \ldots \ldots \ldots \ldots \ldots$

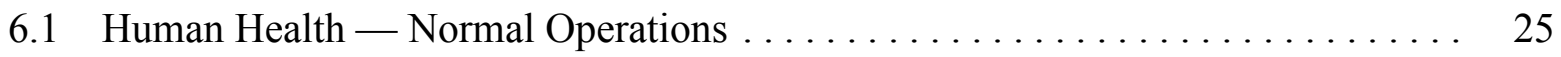

6.1 .1 Radiological Impacts . . . . . . . . . . . . . . . . . . . . . 25

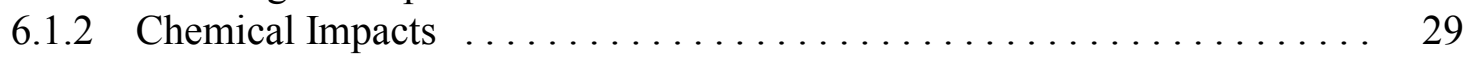

6.2 Human Health - Accident Conditions . . . . . . . . . . . . . . . . . . 29

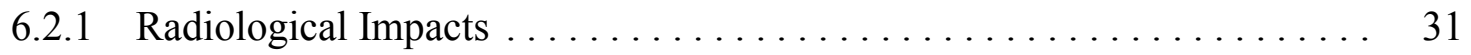

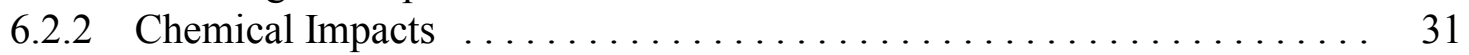

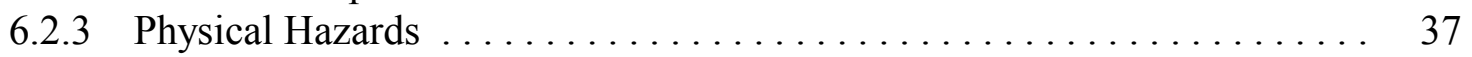

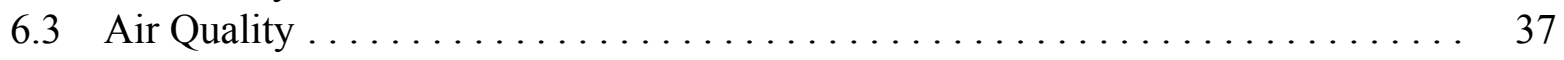

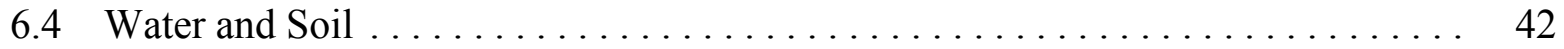

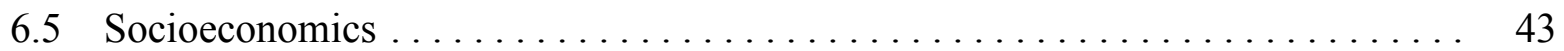

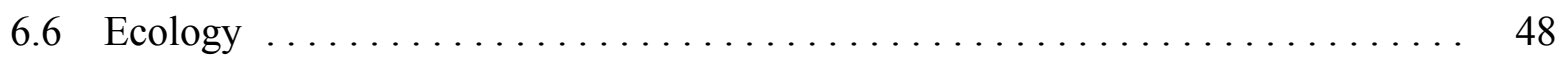

6.6.1 Disposal of 500,000 Metric Tons of $\mathrm{UF}_{4} \ldots \ldots \ldots \ldots \ldots \ldots \ldots$

6.6.2 Disposal of 630,000 Metric Tons of $\mathrm{UF}_{4} \ldots \ldots \ldots \ldots \ldots \ldots \ldots \ldots$

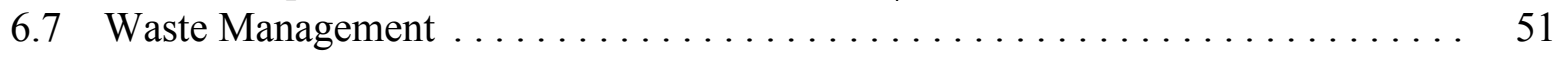

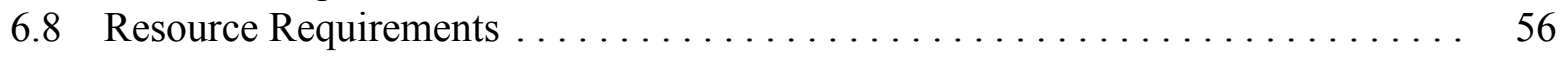

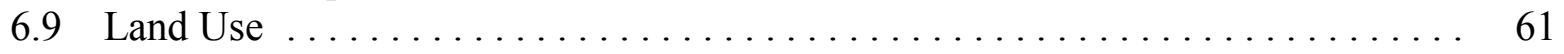

6.10 Other Impacts Considered but Not Analyzed in Detail . . . . . . . . . . . . 62 


\section{CONTENTS (Cont.)}

7 IMPACTS OF OPTIONS - POST-CLOSURE PHASE $\ldots \ldots \ldots \ldots \ldots \ldots \ldots \ldots$

7.1 Human Health - Normal Operations $\ldots \ldots \ldots \ldots \ldots \ldots \ldots \ldots \ldots \ldots \ldots$

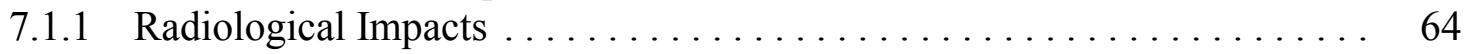

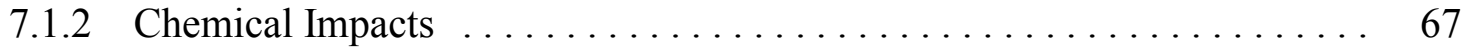

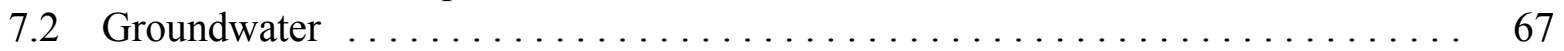

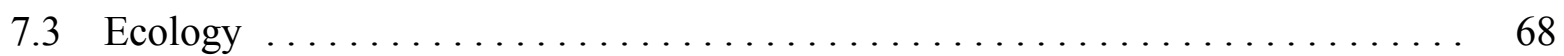

7.3.1 Disposal of 500,000 Metric Tons of $\mathrm{UF}_{4} \ldots \ldots \ldots \ldots \ldots \ldots \ldots$

7.3.2 Disposal of 630,000 Metric Tons of $\mathrm{UF}_{4} \ldots \ldots \ldots \ldots \ldots \ldots \ldots$

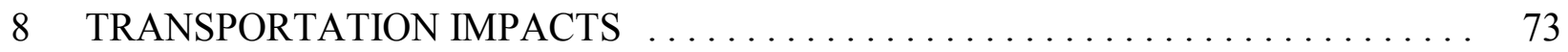

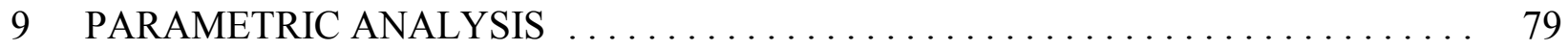

9.1 Human Health - Normal Operations $\ldots \ldots \ldots \ldots \ldots \ldots \ldots \ldots \ldots \ldots \ldots \ldots$

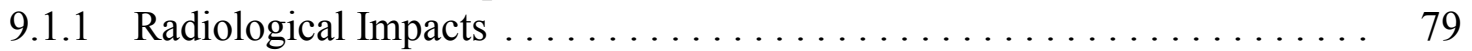

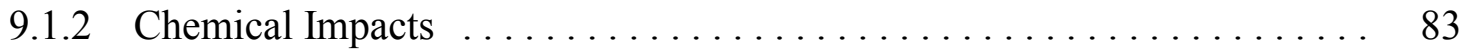

9.2 Human Health - Accident Conditions . . . . . . . . . . . . . . . . . 83

9.2.1 Radiological and Chemical Impacts $\ldots \ldots \ldots \ldots \ldots \ldots \ldots \ldots \ldots . \ldots \ldots$

9.2 .2 Physical Hazards $\ldots \ldots \ldots \ldots \ldots \ldots \ldots \ldots \ldots \ldots \ldots \ldots \ldots \ldots \ldots \ldots$

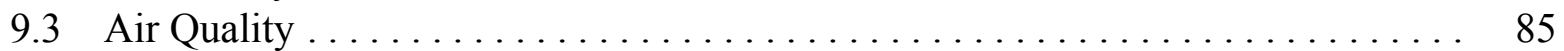

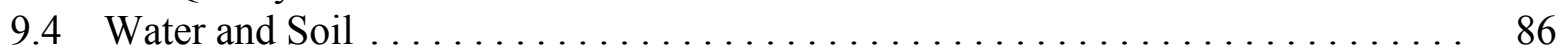

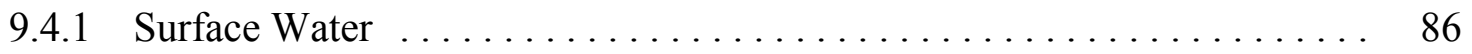

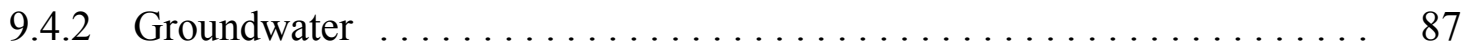

9.4 .3 Soil .................................... 87

9.5 Socioeconomics ..................................... 88

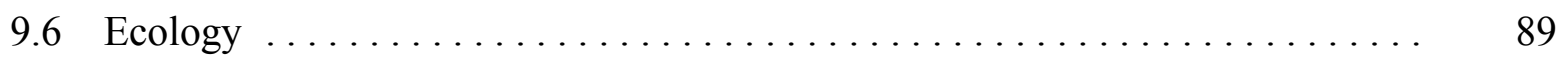

9.7 Waste Management ................................... 90

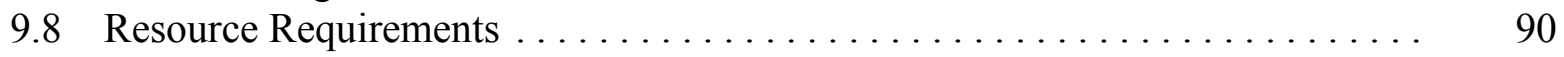

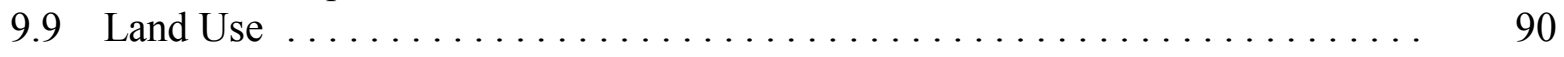

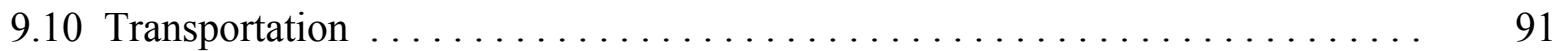

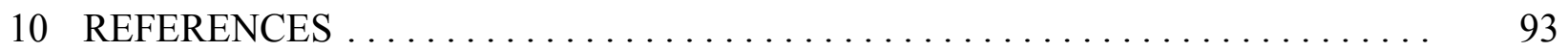

\section{TABLES}

1.1 Scope of the Depleted $\mathrm{UF}_{4}$ Disposal Analysis . ...................... 3

2.1 Impacts from $\mathrm{UF}_{4}$ Disposal Options during the Operational Phase $\ldots \ldots \ldots \ldots \ldots$

2.2 Impacts from $\mathrm{UF}_{4}$ Disposal Options during the Post-Closure Phase $\ldots \ldots \ldots \ldots \ldots$ 


\section{TABLES (Cont.)}

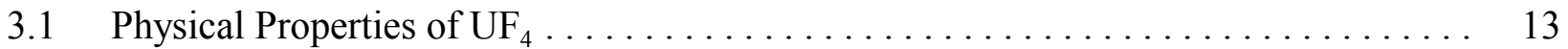

4.1 Representative Dry Environmental Setting Assumptions as Defined

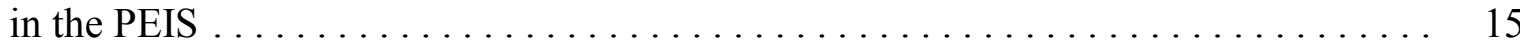

4.2 General Criteria Used to Summarize and Describe the Magnitude

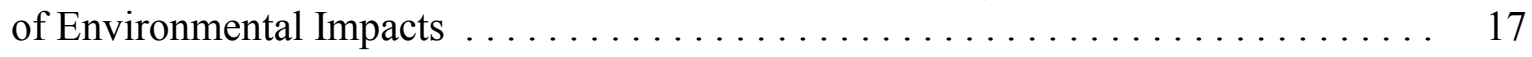

5.1 Estimated Content and Number of $\mathrm{UF}_{4}$ Containers Requiring Disposal $\ldots \ldots \ldots 21$

5.2 Site Land Parameters at the Wasteform Facility $\ldots \ldots \ldots \ldots \ldots \ldots \ldots \ldots \ldots \ldots$

5.3 Site Land Parameters for Disposal of 500,000 Metric Tons of $U_{4} \ldots \ldots \ldots 22$

5.4 Site Land Parameters for Disposal of 630,000 Metric Tons of $U_{4} \ldots \ldots \ldots$

6.1 Estimated Radiological Doses from Normal Operations under $\mathrm{UF}_{4}$

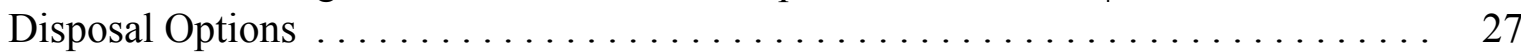

6.2 Estimated Latent Cancer Fatality Risks from Normal Operations

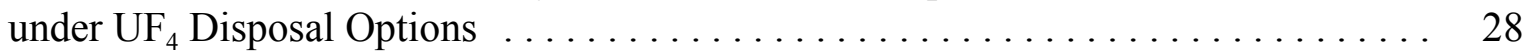

6.3 Accidents Considered under $\mathrm{UF}_{4}$ Disposal Options $\ldots \ldots \ldots \ldots \ldots \ldots \ldots \ldots$

6.4 Estimated Radiological Doses per Accident Occurrence under $\mathrm{UF}_{4}$

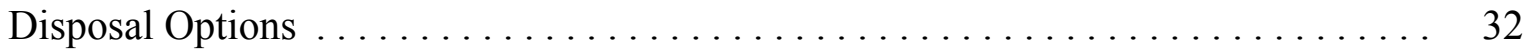

6.5 Estimated Radiological Health Risks per Accident Occurrence under $\mathrm{UF}_{4}$ Disposal Options

6.6 Number of Persons with Potential for Adverse Effects from Chemical Exposures from Accidents under $U_{4}$ Disposal Options . . . . . . . . . . . . . . 34

6.7 Number of Persons with Potential for Irreversible Adverse Effects

from Chemical Exposures from Accidents under $\mathrm{UF}_{4}$ Disposal Options

6.8 Potential Impacts on Human Health from Physical Hazards from Accidents

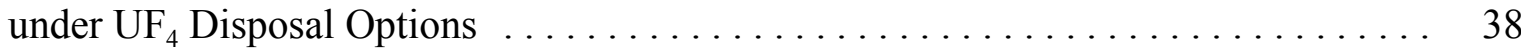

6.9 Pollutant Emissions from Construction Activities Associated with Disposal Facilities for 630,000 Metric Tons of $\mathrm{UF}_{4}$ Disposed of in 30-Gallon Drums 


\section{TABLES (Cont.)}

6.10 Scaling Factors for Criteria Pollutant Emissions from Construction and Operations under $\mathrm{UF}_{4}$ Disposal Options, Relative to Emissions from Construction Associated with Disposal Facilities for 630,000 Metric Tons of $\mathrm{UF}_{4}$ Disposed of in 30-Gallon Drums

6.11 Maximum Concentrations at Three Receptor Distances Resulting from the Construction of a Mine and from the Operation of Vaults

6.12 Environmental Parameters for the Wasteform Facility ................. 43

6.13 Environmental Parameters for a Shallow Earthen Structure ................ 44

6.14 Environmental Parameters for a Vault $\ldots \ldots \ldots \ldots \ldots \ldots \ldots \ldots \ldots \ldots \ldots \ldots \ldots$

6.15 Environmental Parameters for a Mined Cavity ................... 46

6.16 Socioeconomic Impacts from $\mathrm{UF}_{4}$ Disposal Options $\ldots \ldots \ldots \ldots \ldots \ldots \ldots \ldots$

6.17 Impacts on Ecological Resources from $\mathrm{UF}_{4}$ Disposal Facility Construction $\ldots \ldots \ldots \quad 49$

6.18 Estimated Construction Wastes Generated under $\mathrm{UF}_{4}$ Disposal Options $\ldots \ldots \ldots \ldots \quad 52$

6.19 Estimated Annual Radioactive and Nonhazardous Waste Streams from Wasteform Facility Operations . . . . . . . . . . . . . . . . . . . . . . 54

6.20 Variations in Wasteform Facility Operations under $\mathrm{UF}_{4}$ Disposal Options $\ldots \ldots \ldots . \quad 55$

6.21 Materials and Resources Required during Construction of Shallow Earthen Structure Disposal Facility $\ldots \ldots \ldots \ldots \ldots \ldots \ldots \ldots .57$

6.22 Resources Required during Operations of Shallow Earthen Structure

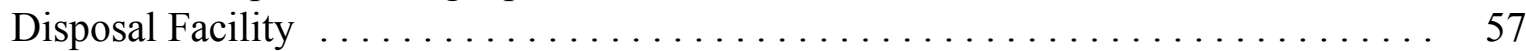

6.23 Materials and Resources Required during Construction of Vault

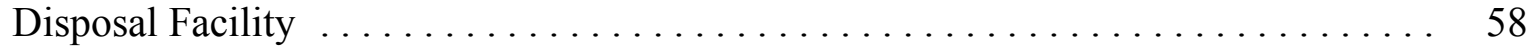

6.24 Resources Required during Operations of Vault Disposal Facility . . . . . . . . . . 58

6.25 Total Materials and Resources Required during Construction of Mined Cavity Facility . . . . . . . . . . . . . . . . . . . . . . . . . . . . . . 59

6.26 Resources Required during Operations of Mined Cavity Facility . . . . . . . . . . . 59 


\section{TABLES (Cont.)}

6.27 Total Materials and Resources Required during Construction

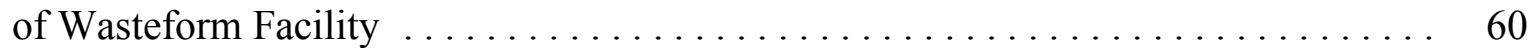

6.28 Total Concrete Required for Wasteform Facility $\ldots \ldots \ldots \ldots \ldots \ldots \ldots \ldots$

6.29 Resources Required during Operations of Wasteform Facility . . . . . . . . . . . . 61

7.1 Estimated Human Health Impacts to the MEI under $\mathrm{UF}_{4}$ Disposal Options

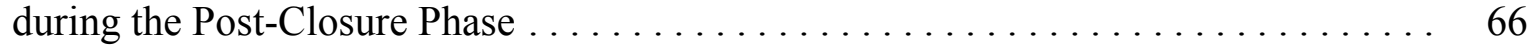

7.2 Concentrations 1,000 Years after Dilution at the Water Table for Disposal of 500,000 Metric Tons of $\mathrm{UF}_{4} \ldots \ldots \ldots \ldots \ldots \ldots \ldots \ldots \ldots \ldots \ldots \ldots$

7.3 Concentrations 1,000 Years after Dilution at the Water Table for Disposal of 630,000 Metric Tons of $\mathrm{UF}_{4} \ldots \ldots \ldots \ldots \ldots \ldots \ldots \ldots \ldots \ldots \ldots \ldots \ldots$

7.4 Potential Radiological and Chemical Impacts on Aquatic Biota from Failure of a Disposal Facility $\ldots \ldots \ldots \ldots \ldots \ldots \ldots \ldots \ldots \ldots \ldots$

$8.1 \quad$ Total Risks from Routine Shipment of $\mathrm{UF}_{4} \ldots \ldots \ldots \ldots \ldots \ldots \ldots \ldots \ldots \ldots$

8.2 Total Risks from Accidents during Shipment of $\mathrm{UF}_{4} \ldots \ldots \ldots \ldots \ldots \ldots \ldots \ldots$

8.3 Potential Consequences to the Population from Severe Accidents

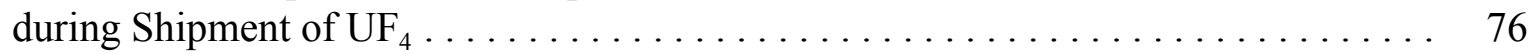

8.4 Potential Consequences to the MEI from Severe Accidents

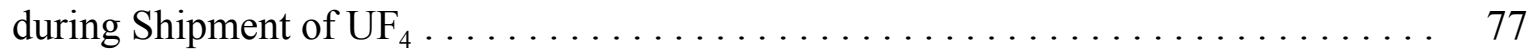

8.5 Consequences to the MEI during Routine Shipment of $\mathrm{UF}_{4} \ldots \ldots \ldots \ldots \ldots \ldots \ldots$

9.1 Socioeconomic Impacts from $\mathrm{UF}_{4}$ Disposal Options: Parametric Analysis . . . . . . 88

\section{FIGURES}

4.1 Areas of Potential Impact Evaluated in the Depleted $\mathrm{UF}_{4}$ Disposal Analysis . . . . . . 16

9.1 Estimated Annual Collective Dose to Involved Workers from the Disposal of $30-$ Gallon Drums . . . . . . . . . . . . . . . . . . . . . . . . . . 80 


\section{FIGURES (Cont.)}

9.2 Estimated Annual Average Individual Dose to Involved Workers from the

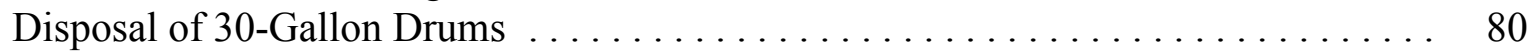

9.3 Estimated Annual Collective Dose to Involved Workers from the Disposal of $55-$ Gallon Drums ....................................... 81

9.4 Estimated Annual Average Individual Dose to Involved Workers from the Disposal of 55 -Gallon Drums $\ldots \ldots \ldots \ldots \ldots \ldots \ldots \ldots \ldots \ldots \ldots \ldots \ldots \ldots . \ldots \ldots$

9.5 Estimated Number of on-the-Job Injuries from the Disposal of $\mathrm{UF}_{4}$

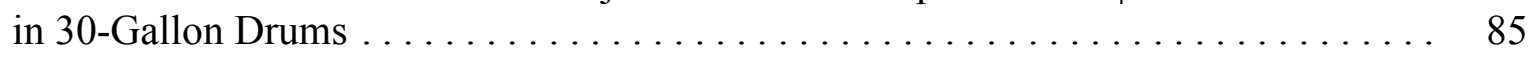

9.6 Estimated Number of on-the-Job Injuries from the Disposal of $\mathrm{UF}_{4}$

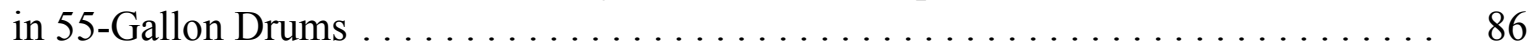

9.7 Estimated Truck Transportation Risks from Shipping $\mathrm{UF}_{4}$ from the

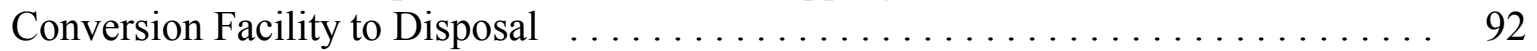

9.8 Estimated Rail Transportation Risks from Shipping $\mathrm{UF}_{4}$ from the Conversion Facility to Disposal 


\section{NOTATION}

The following is a list of acronyms and abbreviations, including units of measure, used in this document. Some acronyms used only in tables are defined in those tables.

\section{ACRONYMS AND ABBREVIATIONS}

\section{General}

BEMR The 1996 Baseline Environmental Management Report

DOE U.S. Department of Energy

DOT U.S. Department of Transportation

EIS environmental impact statement

EPA U.S. Environmental Protection Agency

LCF latent cancer fatality

LLMW low-level mixed waste

LLNL Lawrence Livermore National Laboratory

LLW low-level (radioactive) waste

MC\&A materials control and accountability

MCL maximum contaminant level

MEI maximally exposed individual

MMES Martin Marietta Energy Systems

NEPA National Environmental Policy Act

NRC U.S. Nuclear Regulatory Commission

NTS Nevada Test Site

PEIS programmatic environmental impact statement

$\mathrm{PM}_{10} \quad$ particulate matter with a mean diameter of $10: \mathrm{m}$ or less

USEC United States Enrichment Corporation

WM PEIS Waste Management Programmatic Environmental Impact Statement for Managing Treatment, Storage, and Disposal of Radioactive and Hazardous Waste

\section{Chemicals}

$\begin{array}{llll}\mathrm{CO} & \text { carbon monoxide } & \mathrm{UF}_{4} & \text { uranium tetrafluoride } \\ \mathrm{HC} & \text { hydrocarbons } & \mathrm{UF}_{6} & \text { uranium hexafluoride } \\ \mathrm{HF} & \text { hydrogen fluoride } & \mathrm{UO}_{2} & \text { uranium dioxide } \\ \mathrm{NO}_{\mathrm{x}} & \text { nitrogen oxides } & \mathrm{UO}_{3} \otimes \mathrm{H}_{2} \mathrm{O} & \text { schoepite (hydrous uranium oxide) } \\ \mathrm{SO}_{\mathrm{x}} & \text { sulfur oxides } & \mathrm{U}_{3} \mathrm{O}_{8} & \text { triuranium octaoxide }\end{array}$


UNITS OF MEASURE

$\begin{array}{llll}\mathrm{cm} & \text { centimeter(s) } & : \mathrm{m} & \text { micrometer(s) } \\ \mathrm{cm}^{3} & \text { cubic centimeter(s) } & \mathrm{m} & \text { meter(s) } \\ \mathrm{d} & \text { day(s) } & \mathrm{m}^{3} & \text { cubic meter(s) } \\ \mathrm{ft} & \text { foot (feet) } & \mathrm{mg} & \text { milligram(s) } \\ \mathrm{g} & \text { gram(s) } & \mathrm{mi}^{2} & \text { square mile(s) } \\ \mathrm{gal} & \text { gallon(s) } & \mathrm{min} & \text { minute(s) } \\ \mathrm{gpm} & \text { gallon(s) per minute } & \mathrm{mrem} & \text { millirem(s) } \\ \mathrm{GWh} & \text { gigawatt-hour(s) } & \mathrm{MWh} & \text { megawatt-hour(s) } \\ \mathrm{ha} & \text { hectare(s) } & \mathrm{pCi} & \text { picocurie(s) } \\ \mathrm{in} . & \text { inch(es) } & \mathrm{ppm} & \text { part(s) per million } \\ \mathrm{km} & \text { kilometer(s) } & \mathrm{rad} & \text { radiation absorbed dose(s) } \\ \mathrm{km} & \text { square kilometer(s) } & \mathrm{rem} & \text { roentgen equivalent man } \\ \mathrm{L} & \text { liter(s) } & \text { te } & \text { metric ton(s) } \\ \mathrm{lb} & \text { pound(s) } & \mathrm{yr} & \text { year(s) } \\ : \mathrm{g} & \text { microgram(s) } & & \end{array}$




\title{
ENVIRONMENTAL IMPACTS OF OPTIONS FOR DISPOSAL OF DEPLETED URANIUM TETRAFLUORIDE $\left(\mathrm{UF}_{4}\right)$
}

\author{
F.A. Monette, T. Allison, H.I. Avci, B.M. Biwer, J.P. Butler, Y.-S. Chang, J.-J. Cheng, \\ S.M. Folga, H.M. Hartmann, M.A. Lazaro, D.J. LePoire, D.A. Tomasko, \\ R.A. Van Lonkhuyzen, and B.D. Wilkins
}

\begin{abstract}
The U.S. Department of Energy (DOE) evaluated options for managing its depleted uranium hexafluoride $\left(\mathrm{UF}_{6}\right)$ inventory in the Programmatic Environmental Impact Statement for the Long-Term Management and Use of Depleted Uranium Hexafluoride (PEIS) of April 1999. Along with the impacts from other management options, the PEIS discussed the environmental impacts from the disposal of depleted uranium oxide, which could result from the chemical conversion of depleted $\mathrm{UF}_{6}$. It has been suggested that the depleted $\mathrm{UF}_{6}$ could also be converted to uranium tetrafluoride $\left(\mathrm{UF}_{4}\right)$ and disposed of. This report considers the potential environmental impacts from the disposal of DOE's depleted $\mathrm{UF}_{6}$ inventory after its conversion to $\mathrm{UF}_{4}$. The impacts were evaluated for the same three disposal facility options that were considered in the PEIS for uranium oxide: shallow earthen structures, belowground vaults, and mines. They were evaluated for a dry environmental setting representative of the western United States. To facilitate comparisons and future decision making, the depleted $\mathrm{UF}_{4}$ disposal analyses performed and the results presented in this report are at the same level of detail as that in the PEIS.
\end{abstract}

\section{INTRODUCTION}

\subsection{BACKGROUND}

The U.S. Department of Energy (DOE) evaluated options for managing its depleted uranium hexafluoride $\left(\mathrm{UF}_{6}\right)$ inventory in the Programmatic Environmental Impact Statement for the Long-Term Management and Use of Depleted Uranium Hexafluoride (depleted UF ${ }_{6}$ PEIS) published in April 1999 (DOE 1999). The PEIS discussed the environmental impacts associated with the disposal of two forms of depleted uranium oxide that would result from the chemical conversion of DOE's depleted $\mathrm{UF}_{6}$ inventory: triuranium octaoxide $\left(\mathrm{U}_{3} \mathrm{O}_{8}\right)$ and uranium dioxide $\left(\mathrm{UO}_{2}\right)$. Since the publication of the PEIS, it has been suggested that the depleted $\mathrm{UF}_{6}$ could also be converted to $\mathrm{UF}_{4}$ 
and then disposed of. Because of differences in the chemical properties of uranium oxide and $\mathrm{UF}_{4}$, it was unclear if the impacts from the disposal of uranium oxide estimated in the PEIS would be representative of the impacts from the disposal of depleted $U_{4}$. Therefore, the potential impacts from $\mathrm{UF}_{4}$ disposal were estimated and are discussed in this report.

To facilitate comparisons and future decision making, the level of detail at which the depleted $\mathrm{UF}_{4}$ disposal analyses were performed and the level at which the results are presented in this report are the same levels as those used in the PEIS for disposal as an oxide. For the same reasons, the assumptions made and the methodologies used to evaluate environmental impacts were similar to those used in the PEIS.

\subsection{SCOPE}

This report considers the potential environmental impacts associated with the disposal of DOE's depleted $\mathrm{UF}_{6}$ inventory after its chemical conversion to $\mathrm{UF}_{4}$ at a conversion facility. The environmental impacts associated with the conversion itself are not included. The scope of this assessment is summarized in Table 1.1 and discussed below.

This report evaluates the disposal of two $\mathrm{UF}_{6}$ inventories: (1) 560,000 metric tons of depleted $\mathrm{UF}_{6}$ (contained in about 46,400 cylinders), corresponding to the DOE inventory prior to privatization of the United States Enrichment Corporation (USEC) in 1993, and (2) 705,000 metric tons of $\mathrm{UF}_{6}$ (contained in about 57,600 cylinders), which is the total inventory for which DOE has been responsible after signing two memoranda of agreement with USEC in 1998. Both inventories were considered to facilitate comparisons with the PEIS. Following conversion, the two $\mathrm{UF}_{6}$ inventories correspond to 500,000 and 630,000 metric tons of $\mathrm{UF}_{4}$, respectively. For each inventory, impacts were evaluated for disposal in both 30-gal (110-L) and 55-gal (208-L) drums. A parametric

analysis was also performed, similar to what was done for disposal as an oxide in the PEIS, to evaluate the disposal of $50 \%$ and $25 \%$ of the original DOE inventory.

The potential environmental impacts from disposal of $\mathrm{UF}_{4}$ were evaluated for the same three disposal facility options that were considered in the PEIS for uranium oxide: shallow earthen structures, belowground vaults, and mines. Although the PEIS evaluated two physical forms for disposal, grouted and ungrouted oxide, only ungrouted $\mathrm{UF}_{4}$ is evaluated in this report. Grouted $\mathrm{UF}_{4}$ was considered but is not analyzed in detail because $\mathrm{UF}_{4}$ forms the corrosive product hydrogen fluoride (HF) in the presence of water and is thus considered not suitable for grouting (Folga and Kier 2001).

The environmental impacts from disposal of $\mathrm{UF}_{4}$ were evaluated for a representative dry environmental setting, typical of the western United States. In the PEIS, the disposal analyses were conducted for both a representative dry setting and a representative wet setting (typical of the eastern 
TABLE 1.1 Scope of the Depleted $\mathrm{UF}_{4}$ Disposal Analysis

\begin{tabular}{|c|c|}
\hline Parameter & Assumption \\
\hline General approach & $\begin{array}{l}\text { Same assumptions and methodologies as those used for the } \\
\text { disposal of depleted uranium oxide in the depleted } \mathrm{UF}_{6} \text { PEIS } \\
\text { (as appropriate) }\end{array}$ \\
\hline Disposal form & Bulk (ungrouted) uranium tetrafluoride $\left(\mathrm{UF}_{4}\right)$ \\
\hline Disposal options & $\begin{array}{l}\text { Shallow earthen structures } \\
\text { Vaults } \\
\text { Mine }\end{array}$ \\
\hline Source of engineering data & Folga and Kier (2001) \\
\hline $\mathrm{UF}_{6}$ inventory considered & $\begin{array}{l}\text { Two inventories: } \\
\text { (1) } 560,000 \text { metric tons (pre-1993 DOE inventory) } \\
\text { (2) } 705,000 \text { metric tons (above plus inventory either transferred } \\
\text { or to be transferred from USEC) }\end{array}$ \\
\hline Equivalent $\mathrm{UF}_{4}$ inventory & $\begin{array}{l}\text { (1) } 500,000 \text { metric tons } \\
\text { (2) } 630,000 \text { metric tons }\end{array}$ \\
\hline Packaging options & $\begin{array}{l}\text { Two options for each inventory: } \\
\text { (1) } 30 \text {-gal drums } \\
\text { (2) } 55 \text {-gal drums }\end{array}$ \\
\hline Environmental setting & $\begin{array}{l}\text { Representative "dry" setting, as defined and evaluated in the } \\
\text { PEIS }\end{array}$ \\
\hline Emplacement period & $\begin{array}{l}\text { (1) } 20 \text { years for } 560,000 \text { metric tons of depleted } U_{F} \\
\text { (2) } 25 \text { years for } 705,000 \text { metric tons of depleted } U_{6}\end{array}$ \\
\hline Parametric analysis & Disposal of $25 \%$ and $50 \%$ of 560,000 metric tons of depleted $U_{6}$ \\
\hline
\end{tabular}


United States). The PEIS showed that disposal as an oxide in a wet environment would probably not meet the current regulatory requirements for disposal of radioactive material, a finding consistent with previous analyses by the U.S. Nuclear Regulatory Commission (NRC 1994a). In addition, an arid climate provides the most favorable disposal conditions and is consistent with current disposal practices. Consequently, disposal of $\mathrm{UF}_{4}$ in a wet environmental setting was not analyzed in this report. A specific arid location for the disposal facility, which could be a DOE facility or a commercial facility operating under a radioactive materials license issued by the NRC or an Agreement State, will be determined at a later date.

The technical basis for this analysis was the report Engineering Analysis for Disposal of Depleted Uranium Tetrafluoride (UF $)$ (Folga and Kier 2001). This $\mathrm{UF}_{4}$ engineering report was prepared specifically to support the $\mathrm{UF}_{4}$ disposal analysis. To facilitate comparisons with the PEIS, the $\mathrm{UF}_{4}$ engineering report used the same methods and assumptions, to the extent practicable, as those used in the Depleted Uranium Management Program; the Engineering Analysis Report for the Long-Term Management of Depleted Uranium Hexafluoride (Lawrence Livermore National Laboratory [LLNL] 1997), which was prepared to support the PEIS. For each disposal option, the $\mathrm{UF}_{4}$ engineering report provides preconceptual $\mathrm{UF}_{4}$ disposal facility design data, including descriptions of facility layouts and resource requirements; estimates of effluents, wastes, and emissions; and descriptions of potential accident scenarios. In addition, the report provides a brief discussion of historical $\mathrm{UF}_{4}$ disposal experience that supports future consideration of $\mathrm{UF}_{4}$ as a suitable disposal form.

As in the PEIS, the environmental impacts from the disposal of $\mathrm{UF}_{4}$ were estimated for two phases: (1) the operational phase, which includes construction of the facility and the period in which waste would be actively placed into disposal units, and (2) the post-closure phase, which considers hundreds of years in the future, beyond the time that any engineered disposal facilities would be expected to function as designed. All disposal facilities were assumed to fail, or release waste to the environment, at the end of an institutional control period. (Failure was assumed to occur around the year 2140, 100 years after site closure.)

The potential environmental impacts from disposal of $\mathrm{UF}_{4}$ were estimated for an operational period of 40 years. It was assumed that waste emplacement would occur over 20 years for the 560,000 metric ton $\mathrm{UF}_{6}$ inventory and over 25 years for the 705,000 metric ton inventory. In addition, long-term impacts from potential groundwater contamination were estimated for a period of 1,000 years following the failure of the disposal facility. Consequences were evaluated in the areas of human health and safety (impacts from both normal operations and accidents), air quality, water and soil, socioeconomics, ecology, waste management, resource requirements, land use, cultural resources, and environmental justice. The assessment considered impacts to workers and the public that could result from construction of a disposal facility, normal operation of the facility, accidents, and transportation of $\mathrm{UF}_{4}$ to the disposal facility. 


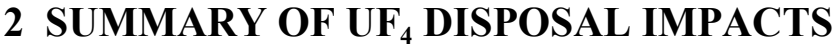

This section provides a summary of the potential environmental impacts associated with the disposal of depleted $\mathrm{UF}_{4}$. The summary is based on the information provided in the remainder of this report. As described above, potential environmental impacts were evaluated for shallow earthen structures, vaults, and a mine during two phases: the operational phase and post-closure phase. The estimated environmental impacts during the operational phase are summarized in Table 2.1; post-closure impacts are summarized in Table 2.2. Results are presented in the same format as that used in the PEIS to facilitate comparisons.

Analysis of the operational phase covered facility construction and the time during which waste would be actively placed in disposal units. Analysis of the post-closure phase considered potential impacts 1,000 years after the disposal units were assumed to fail (i.e., release uranium material beyond the boundaries of the disposal unit).

The following is a general summary of potential environmental impacts during the operational phase taken from information provided in this report in Table 2.1, Section 6 (operational impacts), and Section 8 (transportation impacts):

C Potential Adverse Impacts. Potential adverse impacts during the operational phase would be small and generally similar for all three disposal facility options and both packaging options. Minor to moderate impacts, such as particulate air emissions (i.e., dust), could occur during construction activities, although these impacts would be temporary and easily mitigated by common engineering and construction practices. Potential health impacts during waste emplacement activities would likely be small and limited to involved and noninvolved workers. (Involved workers are defined as those workers directly involved with the handling and disposal of the depleted $\mathrm{UF}_{4}$; noninvolved workers are those on-site workers who are not directly involved with disposal activities.) Involved workers would be exposed to low levels of external radiation and subject to some risk of injury or fatality from occupational accidents. Low-probability facility accidents that could release $\mathrm{UF}_{4}$ to the environment could occur during interim storage and handling; however, the maximum consequences of such accidents were estimated to be well below levels expected to cause an appreciable health risk to noninvolved workers or the public. 
TABLE 2.1 Impacts from $\mathrm{UF}_{4}$ Disposal Options during the Operational Phase

\begin{tabular}{|c|c|c|}
\hline Disposal in Shallow Earthen Structures & Disposal in Vaults & Disposal in a Mine \\
\hline \multicolumn{3}{|c|}{ Human Health-Normal Operations: Radiological ${ }^{b}$} \\
\hline Involved Workers: & Involved Workers: & Involved Workers: \\
\hline Total collective dose: & Total collective dose: & Total collective dose: \\
\hline $\begin{array}{l}280-320 \text { person-rem } \\
(350-400 \text { person-rem) }\end{array}$ & $\begin{array}{l}280-320 \text { person-rem } \\
(350-400 \text { person-rem) }\end{array}$ & $\begin{array}{l}360-400 \text { person-rem } \\
(450-500 \text { person-rem) }\end{array}$ \\
\hline Total number of LCFs: & Total number of LCFs: & Total number of LCFs: \\
\hline $0.1 \mathrm{LCF}$ & $0.1 \mathrm{LCF}$ & $0.1-0.2 \mathrm{LCF}$ \\
\hline$(0.1-0.2 \mathrm{LCF})$ & $(0.1-0.2 \mathrm{LCF})$ & $(0.1-0.2 \mathrm{LCF})$ \\
\hline Noninvolved Workers: & Noninvolved Workers: & Noninvolved Workers: \\
\hline No impacts & No impacts & No impacts \\
\hline General Public: & General Public: & General Public: \\
\hline No impacts & No impacts & No impacts \\
\hline \multicolumn{3}{|c|}{ Human Health - Normal Operations: Chemical } \\
\hline Noninvolved Workers: & Noninvolved Workers: & Noninvolved Workers: \\
\hline No impacts & No impacts & No impacts \\
\hline General Public: & General Public: & General Public: \\
\hline No impacts & No impacts & No impacts \\
\hline \multicolumn{3}{|c|}{ Human Health-Accidents: Radiological } \\
\hline $\begin{array}{l}\text { Bounding accident: Earthquake damage to } \\
\text { product receiving building }\end{array}$ & $\begin{array}{l}\text { Bounding accident: Earthquake damage to } \\
\text { product receiving building }\end{array}$ & $\begin{array}{l}\text { Bounding accident: Earthquake damage to } \\
\text { product receiving building }\end{array}$ \\
\hline Bounding accident frequency: & Bounding accident frequency: & Bounding accident frequency: \\
\hline 1 in 100 years to 1 in 10,000 years & 1 in 100 years to 1 in 10,000 years & 1 in 100 years to 1 in 10,000 years \\
\hline Release: $275 \mathrm{lb} \mathrm{UF}_{4}$ & Release: $275 \mathrm{lb} \mathrm{UF}_{4}$ & Release: $275 \mathrm{lb} \mathrm{UF}_{4}$ \\
\hline Noninvolved Workers: & Noninvolved Workers: & Noninvolved Workers: \\
\hline $\begin{array}{l}\text { Bounding accident consequences } \\
\text { (per occurrence): }\end{array}$ & $\begin{array}{l}\text { Bounding accident consequences } \\
\text { (per occurrence): }\end{array}$ & $\begin{array}{l}\text { Bounding accident consequences } \\
\text { (per occurrence): }\end{array}$ \\
\hline Dose to MEI: 5 rem & Dose to MEI: 5 rem & Dose to MEI: 5 rem \\
\hline Risk of LCF to MEI: 0.002 & Risk of LCF to MEI: 0.002 & Risk of LCF to MEI: 0.002 \\
\hline Collective dose: 0.22 person-rem & Collective dose: 0.22 person-rem & Collective dose: 0.22 person-rem \\
\hline Number of LCFs: 0.00009 & Number of LCFs: 0.00009 & Number of LCFs: 0.00009 \\
\hline General Public: & General Public: & General Public: \\
\hline $\begin{array}{l}\text { Bounding accident consequences } \\
\text { (per occurrence): }\end{array}$ & $\begin{array}{l}\text { Bounding accident consequences } \\
\text { (per occurrence): }\end{array}$ & $\begin{array}{l}\text { Bounding accident consequences } \\
\text { (per occurrence): }\end{array}$ \\
\hline Dose to MEI: 0.039 rem & Dose to MEI: 0.039 rem & Dose to MEI: 0.039 rem \\
\hline Risk of LCF to MEI: $2 \times 10^{-5}$ & Risk of LCF to MEI: $2 \times 10^{-5}$ & Risk of LCF to MEI: $2 \times 10^{-5}$ \\
\hline $\begin{array}{l}\text { Collective dose to population } \\
\text { within } 50 \text { miles: } 0.05 \text { person-rem }\end{array}$ & $\begin{array}{l}\text { Collective dose to population } \\
\text { within } 50 \text { miles: } 0.05 \text { person-rem }\end{array}$ & $\begin{array}{l}\text { Collective dose to population } \\
\text { within } 50 \text { miles: } 0.05 \text { person-rem }\end{array}$ \\
\hline $\begin{array}{l}\text { Number of LCFs in population } \\
\text { within } 50 \text { miles: } 3 \times 10^{-5} \text { LCF }\end{array}$ & $\begin{array}{l}\text { Number of LCFs in population } \\
\text { within } 50 \text { miles: } 3 \times 10^{-5} \text { LCF }\end{array}$ & $\begin{array}{l}\text { Number of LCFs in population } \\
\text { within } 50 \text { miles: } 3 \times 10^{-5} \text { LCF }\end{array}$ \\
\hline
\end{tabular}


TABLE 2.1 (Cont.)

\begin{tabular}{|c|c|c|}
\hline Disposal in Shallow Earthen Structures & Disposal in Vaults & Disposal in a Mine \\
\hline \multicolumn{3}{|c|}{ Human Health-Accidents: Chemical } \\
\hline $\begin{array}{l}\text { Bounding accident: Earthquake damage to } \\
\text { product receiving building }\end{array}$ & $\begin{array}{l}\text { Bounding accident: Earthquake damage to } \\
\text { product receiving building }\end{array}$ & $\begin{array}{l}\text { Bounding accident: Earthquake damage to } \\
\text { product receiving building }\end{array}$ \\
\hline Bounding accident frequency: & Bounding accident frequency: & Bounding accident frequency: \\
\hline 1 in 100 years to 1 in 10,000 years & 1 in 100 years to 1 in 10,000 years & 1 in 100 years to 1 in 10,000 years \\
\hline Release: $275 \mathrm{lb} \mathrm{UF}_{4}$ & Release: $275 \mathrm{lb} \mathrm{UF}_{4}$ & Release: $275 \mathrm{lb} \mathrm{UF}_{4}$ \\
\hline Noninvolved Workers: & Noninvolved Workers: & Noninvolved Workers: \\
\hline $\begin{array}{l}\text { Bounding accident consequences } \\
\text { (per occurrence): }\end{array}$ & $\begin{array}{l}\text { Bounding accident consequences } \\
\text { (per occurrence): }\end{array}$ & $\begin{array}{l}\text { Bounding accident consequences } \\
\text { (per occurrence): }\end{array}$ \\
\hline $\begin{array}{l}\text { Number of persons with potential for } \\
\text { adverse effects: } \\
\quad 3.5 \text { persons }\end{array}$ & $\begin{array}{l}\text { Number of persons with potential for } \\
\text { adverse effects: } \\
\quad 3.5 \text { persons }\end{array}$ & $\begin{array}{l}\text { Number of persons with potential for } \\
\text { adverse effects: } \\
\quad 3.5 \text { persons }\end{array}$ \\
\hline $\begin{array}{l}\text { Number of persons with potential for } \\
\text { irreversible adverse effects: } \\
\quad 2.7 \text { persons }\end{array}$ & $\begin{array}{l}\text { Number of persons with potential for } \\
\text { irreversible adverse effects: } \\
\qquad 2.7 \text { persons }\end{array}$ & $\begin{array}{l}\text { Number of persons with potential for } \\
\text { irreversible adverse effects: } \\
\qquad 2.7 \text { persons }\end{array}$ \\
\hline General Public: & General Public: & General Public: \\
\hline $\begin{array}{l}\text { Bounding accident consequences } \\
\text { (per occurrence): }\end{array}$ & $\begin{array}{l}\text { Bounding accident consequences } \\
\text { (per occurrence): }\end{array}$ & $\begin{array}{l}\text { Bounding accident consequences } \\
\text { (per occurrence): }\end{array}$ \\
\hline $\begin{array}{l}\text { Number of persons with potential for } \\
\text { adverse effects: }\end{array}$ & $\begin{array}{l}\text { Number of persons with potential for } \\
\text { adverse effects: }\end{array}$ & $\begin{array}{l}\text { Number of persons with potential for } \\
\text { adverse effects: }\end{array}$ \\
\hline $\begin{array}{l}\text { Number of persons with potential } \\
\text { for irreversible adverse effects: } \\
\quad 0.8 \text { person }\end{array}$ & $\begin{array}{l}\text { Number of persons with potential } \\
\text { for irreversible adverse effects: } \\
\quad 0.8 \text { person }\end{array}$ & $\begin{array}{l}\text { Number of persons with potential } \\
\text { for irreversible adverse effects: } \\
\quad 0.8 \text { person }\end{array}$ \\
\hline \multicolumn{3}{|c|}{ Human Health - Accidents: Physical Hazards } \\
\hline $\begin{array}{l}\text { Construction and Operations: } \\
\text { All Workers: } \\
\text { Less than } 1(0.13-0.16) \text { fatality, } \\
\text { approximately } 88-105 \text { injuries } \\
\text { (Less than } 1(0.15-0.17) \text { fatality, } \\
\text { approximately } 103-123 \text { injuries) }\end{array}$ & $\begin{array}{l}\text { Construction and Operations: } \\
\text { All Workers: } \\
\text { Less than } 1(0.23-0.25) \text { fatality, } \\
\text { approximately } 138-158 \text { injuries } \\
\text { (Less than } 1(0.28) \text { fatality, } \\
\text { approximately } 166-187 \text { injuries) }\end{array}$ & $\begin{array}{l}\text { Construction and Operations: } \\
\text { All Workers: } \\
\text { Less than } 1(0.59-0.66) \text { fatality, } \\
\text { approximately } 262-300 \text { injuries } \\
\text { (Less than } 1(0.66-0.76) \text { fatality, } \\
\text { approximately } 296-347 \text { injuries) }\end{array}$ \\
\hline \multicolumn{3}{|c|}{ Air Quality } \\
\hline $\begin{array}{l}\text { Construction: } \\
24 \text {-hour } \mathrm{PM}_{10} \text { concentration potentially as } \\
\text { large as } 27 \% \text { of standard; other criteria } \\
\text { pollutant concentrations less than } 13 \% \text { of } \\
\text { respective standards }\end{array}$ & $\begin{array}{l}\text { Construction: } \\
24 \text {-hour } \mathrm{PM}_{10} \text { concentration potentially as } \\
\text { large as } 27 \% \text { of standard; other criteria } \\
\text { pollutant concentrations less than } 13 \% \text { of } \\
\text { respective standards }\end{array}$ & $\begin{array}{l}\text { Construction: } \\
24 \text {-hour } \mathrm{PM}_{10} \text { concentration potentially as } \\
\text { large as } 27 \% \text { of standard; other criteria } \\
\text { pollutant concentrations less than } 13 \% \text { of } \\
\text { respective standards }\end{array}$ \\
\hline $\begin{array}{l}\text { Operations: } \\
\text { Annual } \mathrm{NO}_{\mathrm{x}} \text { concentration potentially as } \\
\text { large as } 15 \% \text { of standard; other criteria } \\
\text { pollutant concentrations less than } 15 \% \text { of } \\
\text { respective standards }\end{array}$ & $\begin{array}{l}\text { Operations: } \\
\text { Annual } \mathrm{NO}_{\mathrm{x}} \text { concentration potentially as } \\
\text { large as } 15 \% \text { of standard; other criteria } \\
\text { pollutant concentrations less than } 15 \% \text { of } \\
\text { respective standards }\end{array}$ & $\begin{array}{l}\text { Operations: } \\
\text { Annual } \mathrm{NO}_{\mathrm{x}} \text { concentration potentially as } \\
\text { large as } 15 \% \text { of standard; other criteria } \\
\text { pollutant concentrations less than } 15 \% \text { of } \\
\text { respective standards }\end{array}$ \\
\hline
\end{tabular}


TABLE 2.1 (Cont.)

\begin{tabular}{|c|c|c|}
\hline Disposal in Shallow Earthen Structures & Disposal in Vaults & Disposal in a Mine \\
\hline \multicolumn{3}{|c|}{ Water $^{b}$} \\
\hline $\begin{array}{l}\text { Construction: } \\
\text { Negligible impacts to surface water and } \\
\text { groundwater }\end{array}$ & $\begin{array}{l}\text { Construction: } \\
\text { Negligible impacts to surface water and } \\
\text { groundwater }\end{array}$ & $\begin{array}{l}\text { Construction: } \\
\text { Negligible impacts to surface water and } \\
\text { groundwater }\end{array}$ \\
\hline Operations: & Operations: & Operations: \\
\hline $\begin{array}{l}\text { None to negligible impacts to surface water } \\
\text { and groundwater }\end{array}$ & $\begin{array}{l}\text { None to negligible impacts to surface water } \\
\text { and groundwater }\end{array}$ & $\begin{array}{l}\text { None to negligible impacts to surface water } \\
\text { and groundwater }\end{array}$ \\
\hline \multicolumn{3}{|c|}{ Soil $b$} \\
\hline Construction: & Construction: & Construction: \\
\hline Negligible, but temporary, impacts & Moderate to large, but temporary, impacts & Moderate to large, but temporary, impacts \\
\hline Operations: & Operations: & Operations: \\
\hline No impacts & No impacts & No impacts \\
\hline \multicolumn{3}{|c|}{ Socioeconomics } \\
\hline Construction: & Construction: & Construction: \\
\hline $\begin{array}{l}\text { Potential moderate impacts on employment } \\
\text { and income }\end{array}$ & $\begin{array}{l}\text { Potential moderate impacts on employment } \\
\text { and income }\end{array}$ & $\begin{array}{l}\text { Potential moderate impacts on employment } \\
\text { and income }\end{array}$ \\
\hline Operations: & Operations: & Operations: \\
\hline $\begin{array}{l}\text { Potential moderate impacts on employment } \\
\text { and income }\end{array}$ & $\begin{array}{l}\text { Potential moderate impacts on employment } \\
\text { and income }\end{array}$ & $\begin{array}{l}\text { Potential moderate impacts on employment } \\
\text { and income }\end{array}$ \\
\hline \multicolumn{3}{|c|}{ Ecology } \\
\hline $\begin{array}{l}\text { Construction: } \\
\text { Potential moderate impacts to vegetation } \\
\text { and wildlife }\end{array}$ & $\begin{array}{l}\text { Construction: } \\
\text { Potential moderate impacts to vegetation } \\
\text { and wildlife } \\
\text { (Potential moderate to large impacts to } \\
\text { vegetation and wildlife) }\end{array}$ & $\begin{array}{l}\text { Construction: } \\
\text { Potential large impacts to vegetation and } \\
\text { wildlife }\end{array}$ \\
\hline Operations: & Operations: & Operations: \\
\hline Potential adverse impacts to aquatic biota & Potential adverse impacts to aquatic biota & Potential adverse impacts to aquatic biota \\
\hline \multicolumn{3}{|c|}{ Waste Management } \\
\hline $\begin{array}{l}\text { Negligible to low impacts on national waste } \\
\text { management operations }\end{array}$ & $\begin{array}{l}\text { Negligible to low impacts on national waste } \\
\text { management operations }\end{array}$ & $\begin{array}{l}\text { Negligible to low impacts on national waste } \\
\text { management operations }\end{array}$ \\
\hline \multicolumn{3}{|c|}{ Resource Requirements } \\
\hline $\begin{array}{l}\text { No impacts from resource requirements } \\
\text { (such as electricity or materials) on the } \\
\text { local or national scale are expected }\end{array}$ & $\begin{array}{l}\text { No impacts from resource requirements } \\
\text { (such as electricity or materials) on the } \\
\text { local or national scale are expected }\end{array}$ & $\begin{array}{l}\text { No impacts from resource requirements on } \\
\text { the local or national scale are expected; } \\
\text { impacts of electrical requirements for mine } \\
\text { excavation depend on site location }\end{array}$ \\
\hline
\end{tabular}


TABLE 2.1 (Cont.)

\begin{tabular}{|l|l|l|}
\hline \multicolumn{1}{|c|}{ Disposal in Vaults } & \multicolumn{1}{|c|}{ Land Use } \\
\hline \multicolumn{1}{|c|}{ Disposal in a Mine } \\
\hline $\begin{array}{l}\text { Use of approximately } 46 \text { to } 55 \text { acres; } \\
\text { potential moderate impacts } \\
\text { (Use of approximately } 57 \text { to } 67 \text { acres; } \\
\text { potential moderate impacts) }\end{array}$ & $\begin{array}{l}\text { Use of approximately } 67 \text { to } 82 \text { acres; } \\
\text { potential moderate impacts } \\
\text { (Use of approximately } 82 \text { to } 97 \text { acres; } \\
\text { potential moderate impacts) }\end{array}$ & $\begin{array}{l}\text { Use of approximately } 418 \text { to } 587 \text { acres; } \\
\text { potential large impacts, including impacts } \\
\text { from disposal of excavated material and } \\
\text { potential off-site traffic impacts during } \\
\text { construction } \\
\text { (Use of approximately } 547 \text { to } 770 \text { acres; } \\
\text { potential large impacts, including impacts } \\
\text { from disposal of excavated material and } \\
\text { potential off-site traffic impacts during } \\
\text { construction) }\end{array}$ \\
\hline
\end{tabular}

a Impacts are presented for the operational period for disposal of 560,000 metric tons of $\mathrm{UF}_{6}$; impacts from the disposal of 705,000 metric tons of $\mathrm{UF}_{6}$ are shown in parentheses when different. Notation: $\mathrm{LCF}=$ latent cancer fatality; $\mathrm{MEI}=$ maximally exposed individual.

b Radiological impacts are presented as ranges resulting from disposal in 30-gal and 55-gal drums.

C Shallow Earthen Structure, Vault, or Mine. The potential impacts from disposal in a shallow earthen structure, vault, or mine are similar. However, disposal in a mine could create slightly larger potential impacts if the mine would have to be excavated.

C Transportation. Disposal of $\mathrm{UF}_{4}$ would require the shipment of the depleted $\mathrm{UF}_{4}$ from a conversion plant to the disposal facility. The $\mathrm{UF}_{4}$ would be packaged in 30-gal or 55-gal drums and shipped by either truck or train, in accordance with DOE and U.S. Department of Transportation (DOT) regulatory requirements. The greatest risk from $\mathrm{UF}_{4}$ shipments would be from typical traffic accidents, unrelated to the radiological or chemical nature of the $\mathrm{UF}_{4}$. Although less than 1 traffic fatality would be expected to result from shipment of the entire inventory, these vehicle-related risks would be about 5 times larger than the radiological and chemical risks combined.

The potential impacts estimated for the post-closure phase are subject to a great deal of uncertainty because of the extremely long time period considered and the dependence of predictions on the behavior of the waste material as it interacts with soil and water in a distant future environment. The post-closure impacts would depend greatly on the specific disposal facility design and site-specific characteristics. Because of these uncertainties, the assessment assumptions were generally selected to produce conservative estimates of impact, that is, they tend to overestimate the expected impact. Changes in key disposal assumptions could yield significantly different results (see Section 7). 
TABLE 2.2 Impacts from UF $_{4}$ Disposal Options during the Post-Closure Phase ${ }^{a, b}$

\begin{tabular}{|c|c|c|}
\hline Disposal in Shallow Earthen Structures & Disposal in Vaults & Disposal in a Mine \\
\hline \multicolumn{3}{|c|}{ Human Health: Radiological $^{c}$} \\
\hline $\begin{array}{l}\text { General Public: } \\
\text { Annual dose to MEI: } \\
\qquad<2 \times 10^{-8} \mathrm{mrem} / \mathrm{yr} \\
\left(<3 \times 10^{-8} \mathrm{mrem} / \mathrm{yr}\right)\end{array}$ & $\begin{array}{l}\text { General Public: } \\
\text { Annual dose to MEI: } \\
\qquad<3 \times 10^{-8} \mathrm{mrem} / \mathrm{yr} \\
\left(<3 \times 10^{-8} \mathrm{mrem} / \mathrm{yr}\right)\end{array}$ & $\begin{array}{l}\text { General Public: } \\
\text { Annual dose to MEI: } \\
\qquad<2 \times 10^{-6} \mathrm{mrem} / \mathrm{yr} \\
\qquad\left(<3 \times 10^{-6} \mathrm{mrem} / \mathrm{yr}\right)\end{array}$ \\
\hline $\begin{array}{l}\text { Annual cancer risk to MEI: } \\
\quad<1 \times 10^{-14} \text { per year } \\
\left(<1 \times 10^{-14} \text { per year }\right)\end{array}$ & $\begin{array}{l}\text { Annual cancer risk to MEI: } \\
\quad<1 \times 10^{-14} \text { per year } \\
\left(<2 \times 10^{-14} \text { per year }\right)\end{array}$ & $\begin{array}{l}\text { Annual cancer risk to MEI: } \\
\quad<1 \times 10^{-12} \text { per year } \\
\left(<1 \times 10^{-12} \text { per year }\right)\end{array}$ \\
\hline $\begin{array}{l}\text { Collective dose to population } \\
\text { within } 50 \text { miles: } \\
\text { not determined }\end{array}$ & $\begin{array}{l}\text { Collective dose to population } \\
\text { within } 50 \text { miles: } \\
\quad \text { not determined }\end{array}$ & $\begin{array}{l}\text { Collective dose to population } \\
\text { within } 50 \text { miles: } \\
\text { not determined }\end{array}$ \\
\hline $\begin{array}{l}\text { Number of LCFs in population } \\
\text { within } 50 \text { miles: } \\
\text { not determined }\end{array}$ & $\begin{array}{l}\text { Number of LCFs in population } \\
\text { within } 50 \text { miles: } \\
\text { not determined }\end{array}$ & $\begin{array}{l}\text { Number of LCFs in population } \\
\text { within } 50 \text { miles: } \\
\text { not determined }\end{array}$ \\
\hline \multicolumn{3}{|c|}{ Human Health: Chemical } \\
\hline $\begin{array}{l}\text { No impacts to MEI of the general public } \\
\text { from groundwater }\end{array}$ & $\begin{array}{l}\text { No impacts to MEI of the general public } \\
\text { from groundwater }\end{array}$ & $\begin{array}{l}\text { No impacts to MEI of the general public } \\
\text { from groundwater }\end{array}$ \\
\hline \multicolumn{3}{|c|}{ Water } \\
\hline $\begin{array}{l}\text { Negligible impact to groundwater } \\
\text { quality from uranium contamination }\end{array}$ & $\begin{array}{l}\text { Negligible impact to groundwater } \\
\text { quality from uranium contamination }\end{array}$ & $\begin{array}{l}\text { Negligible impact to groundwater } \\
\text { quality from uranium contamination }\end{array}$ \\
\hline \multicolumn{3}{|c|}{ Ecology } \\
\hline $\begin{array}{l}\text { Negligible impacts to wetlands and aquatic } \\
\text { biota from surface water and groundwater } \\
\text { contamination }\end{array}$ & $\begin{array}{l}\text { Negligible impacts to wetlands and aquatic } \\
\text { biota from surface water and groundwater } \\
\text { contamination }\end{array}$ & $\begin{array}{l}\text { Negligible impacts to wetlands and aquatic } \\
\text { biota from surface water and groundwater } \\
\text { contamination }\end{array}$ \\
\hline
\end{tabular}

a Impacts for the post-closure phase were calculated for a time 1,000 years after each disposal facility was assumed to fail. Impacts are presented for the disposal of the 560,000 metric tons of $\mathrm{UF}_{6}$; impacts from the disposal of the 705,000 metric tons of $\mathrm{UF}_{6}$ are shown in parentheses when different. Notation: $\mathrm{LCF}=$ latent cancer fatality; $\mathrm{MEI}=$ maximally exposed individual.

b All disposal facilities would be designed to contain the waste material for at least hundreds of years. Shallow earthen structures would be expected to last several hundred years before failure; vaults and mines would be expected to last several hundreds to thousands of years before failure.

c Radiological impacts are presented as the maximum values considering disposal in both 30 -gal and 55 -gal drums. 
The following general summary of potential environmental impacts during the post-closure phase is taken from information in Table 2.2 and Section 7 (post-closure impacts):

C Potential Adverse Impacts. For all disposal options, essentially no impacts would occur for a disposal facility in a dry environmental setting within 1,000 years after the facility was assumed to fail. Although $\mathrm{UF}_{4}$ was assumed to be released to the environment, the relatively low solubilities of $\mathrm{UF}_{4}$ and the uranium compounds formed by reaction of $\mathrm{UF}_{4}$ with infiltrating water, and the low water infiltration rate typical of dry environmental settings, would result in only a very small amount of uranium reaching the groundwater table within 1,000 years. The maximum dose to an individual assumed to live at the edge of the disposal site and use the contaminated water was estimated to be extremely small, approximately $1 \times 10^{-6} \mathrm{mrem} / \mathrm{yr}$. Possible exposures (on the order of $10 \mathrm{rem} / \mathrm{yr}$ ) could occur for shallow earthen structures and vaults if the cover material were to erode and expose the uranium material; however, this situation would not occur until several thousand years after emplacement or failure, and the exposure could be eliminated by adding new cover material to the top of the waste area.

C Shallow Earthen Structure, Vault, or Mine. Because of the long time periods considered and the fact that the calculations were performed for a time of 1,000 years after each facility was assumed to fail, the potential impacts from disposal in a shallow earthen structure, vault, or mine would be very similar. However, shallow earthen structures would be expected to contain the waste material for a period of at least several hundred years before failure, whereas vaults or a mine would be expected to last even longer - from several hundred years to a thousand years or more. Therefore, vault and mine disposal would provide longer protection of waste. In addition, a vault and a mine would be expected to provide additional protection against erosion of the cover material (and possible surface exposure of the waste material) when compared with shallow earthen structures. The exact time that any disposal facility would perform as designed would depend on the specific facility design and site characteristics and is beyond the scope of this assessment. 


\section{DEPLETED UF ${ }_{4}$ BACKGROUND INFORMATION}

\subsection{PHYSICAL CHARACTERISTICS OF UF}

Uranium tetrafluoride $\left(\mathrm{UF}_{4}\right)$ is often called green-salt because of its characteristic color. Depleted $\mathrm{UF}_{4}$ is a solid composed of agglomerating particles. Its texture is similar to that of baking soda. It is nonvolatile and nonhydroscopic but only slightly soluble in water: about 40 parts per million (ppm) at room temperature (Katz et al. 1986). It has a particle density of $6.5 \mathrm{~g} / \mathrm{cm}^{3}$; however, its bulk density depends on the production process and the properties of the starting uranium compounds, ranging between 2.0 and $4.5 \mathrm{~g} / \mathrm{cm}^{3}$. It is generally an intermediate in the conversion of $\mathrm{UF}_{6}$ to either uranium oxide or uranium metal. The physical properties of depleted $\mathrm{UF}_{4}$ are summarized in Table 3.1.

After exposure to water, $\mathrm{UF}_{4}$ slowly dissolves and undergoes hydrolysis, forming several possible uranium compounds and HF. The time for hydrolysis can be significant. Tomasko (2001) presents a discussion of the chemical reactions possible when $\mathrm{UF}_{4}$ reacts with water in a disposal environment. Possible reaction products include $\mathrm{U}_{3} \mathrm{O}_{8}$, schoepite $\left(\mathrm{UO}_{3} \otimes \mathrm{OH}_{2} \mathrm{O}\right)$, and several uranium complexes. The final form of uranium in solution in the groundwater below a disposal facility is a complex function of the reaction time, physical and chemical attributes of the disposal facility, and geochemistry of the receiving water (Tomasko 2001).

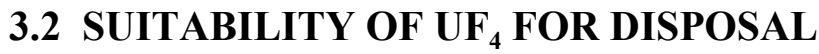

One potential concern with the disposal of depleted $\mathrm{UF}_{4}$ has been the fact that it reacts slowly with moisture at ambient temperature and releases HF, which potentially could enhance the corrosion rate of disposal packages or the disposal facility itself. In addition, $\mathrm{UF}_{4}$ has a higher solubility in water than the uranium oxides $\mathrm{U}_{3} \mathrm{O}_{8}$ and $\mathrm{UO}_{2}$. These were two of the reasons that the conversion to $\mathrm{UF}_{4}$ and disposal of $\mathrm{UF}_{4}$ were considered in the PEIS but not analyzed in detail. Specifically, the disposal of $\mathrm{UF}_{4}$ was not considered in detail in the PEIS for the following reasons:

C A 1994 DOE Request for Recommendations (59 FR 56324) solicited suggestions for potential uses of depleted $\mathrm{UF}_{6}$ and for any technologies that could facilitate the long-term management of depleted $\mathrm{UF}_{6}$. No responses suggested conversion to $\mathrm{UF}_{4}$ or disposal as $\mathrm{UF}_{4}$. 
TABLE 3.1 Physical Properties of $\mathrm{UF}_{4}$

\begin{tabular}{cccc}
\hline $\begin{array}{c}\text { Melting Point } \\
(\mathrm{EC})\end{array}$ & $\begin{array}{c}\text { Bulk Density } \\
\left(\mathrm{g} / \mathrm{cm}^{3}\right)\end{array}$ & $\begin{array}{c}\text { Solubility in Water } \\
\text { Neutral } \mathrm{pH}\end{array}$ & $\begin{array}{c}\text { Inhalation Solubility } \\
\text { Class }^{\mathrm{a}}\end{array}$ \\
\hline $960 \pm 5$ & $2.0-4.5$ & Very slightly soluble & $\mathrm{W}$ \\
\hline
\end{tabular}

a D, W, and Y are inhalation solubility classes established by the International Commission on Radiation Protection. Class D material is very soluble; lung retention time is days. Class W material is relatively insoluble; lung retention time is weeks. Class Y material is relatively insoluble; lung retention time is years.

Source: Martin Marietta Energy Systems (MMES 1990).

C DOE and its contractors felt that there was no particular environmental advantage to $\mathrm{UF}_{4}$ over oxides. On the contrary, there was some concern that $\mathrm{UF}_{4}$ may not meet the waste acceptance criteria for low-level waste (LLW) disposal sites because of HF generation when $\mathrm{UF}_{4}$ reacts with water and because $\mathrm{UF}_{4}$ has a higher solubility than oxides.

C For practical reasons, there was a desire to limit the number of options analyzed in detail in the PEIS to a reasonable number.

C DOE held three scoping meetings in February 1996, soon after the Notice of Intent to prepare the PEIS was issued. There was also a 60-day comment period. Only one individual at one meeting suggested conversion to $\mathrm{UF}_{4}$ or disposal as $\mathrm{UF}_{4}$. Similarly, when the draft PEIS was issued, there was a lengthy public review period (120 days). Approximately 600 comments were received; no comments mentioned conversion to $\mathrm{UF}_{4}$ or disposal as $\mathrm{UF}_{4}$.

Recent information, summarized below, supports future consideration of $\mathrm{UF}_{4}$ as a suitable disposal form.

C Folga and Kier (2001). This engineering analysis report for $\mathrm{UF}_{4}$ disposal reports that a much smaller amount of $\mathrm{UF}_{4}$ than was considered here (approximately 1,870 metric tons) was disposed of in a shallow land LLW disposal facility at the Nevada Test Site (NTS) in the past. Disposal was accomplished by using standard disposal boxes, without any additional overpacking or treatment of the bulk depleted $\mathrm{UF}_{4}$. A review of the properties of depleted $\mathrm{UF}_{4}$ in bulk form by personnel from NTS and the Fernald Site before its shipment to NTS did not reveal any major issues associated with the reactivity of $\mathrm{UF}_{4}$. 
C Croff et al. (2000). This study by Oak Ridge National Laboratory evaluated the acceptability of several depleted uranium conversion products at potential LLW disposal sites to provide a basis for DOE decisions on the preferred depleted uranium product form. The study concluded that depleted $\mathrm{UF}_{4}$ should be acceptable for near-surface disposal at sites such as NTS and Envirocare. Although some characteristics (e.g., very fine particles, sorbed HF) could limit the acceptability of depleted $\mathrm{UF}_{4}$ for disposal, these characteristics reportedly can be controlled via proper technical specifications imposed on the product forms.

C Tomasko (2001). This report evaluated potential groundwater concentrations following failure of a $\mathrm{UF}_{4}$ disposal facility in a representative dry environment for a range of site characteristics. The results of the evaluation, discussed in more detail in Section 7, indicate that uranium groundwater concentrations would remain well below levels of concern for thousands of years, even under conservative site assumptions. 


\section{ASSESSMENT ASSUMPTIONS AND METHODOLOGY}

The areas of potential environmental impact discussed in this report are the same as those discussed in the PEIS (Figure 4.1). For each technical area, analytical methods similar or identical to those used for the PEIS were used to estimate the potential impacts from construction, operations, and accidents for each of the $\mathrm{UF}_{4}$ disposal options. A complete discussion of the methods used for each technical area is provided in Chapter 4 and Appendix $\mathrm{C}$ of the PEIS. Changes to methods or assumptions are noted in Chapters 6 and 7, where appropriate.

In general, the assumptions used to analyze $\mathrm{UF}_{4}$ disposal were the same as those used in the PEIS. A summary of the representative dry environmental setting assumptions is presented in Table 4.1.

The results of the $\mathrm{UF}_{4}$ disposal analysis are presented in this report in the same manner in which the PEIS results were presented. Potential impacts to human health are summarized quantitatively by presenting the estimated number of health effects among workers and members of the general public from potential exposures to radiation and chemicals over the duration of the disposal activities. Potential impacts to water and air quality are summarized by indicating whether or not the estimated pollutant concentrations would be above or below applicable guidelines or standards. Other areas of impact, primarily those for which guidelines or standards are not specifically defined (such as ecological and waste management impacts), are summarized qualitatively by using the terms negligible to low, moderate, and large. A summary of the criteria used to define impacts is provided in Table 4.2.

TABLE 4.1 Representative Dry Environmental Setting Assumptions as Defined in the PEIS

\begin{tabular}{|c|c|}
\hline Parameter & Assumption \\
\hline Population density & Generic setting with low population density $\left(6\right.$ persons $\left./ \mathrm{km}^{2}\right)$ \\
\hline Groundwater & $\begin{array}{l}\text { Disposal facility located either } 500 \mathrm{ft} \text { (shallow earthen } \\
\text { structure or vault) or } 100 \mathrm{ft} \text { (mine) above the water table }\end{array}$ \\
\hline Precipitation & 10 in. per year \\
\hline Water infiltration & $1 \%$ of annual precipitation \\
\hline Meteorological conditions & $\begin{array}{l}\text { Five Western locations were used as examples to determine } \\
\text { a range of meteorological conditions for air dispersion }\end{array}$ \\
\hline
\end{tabular}




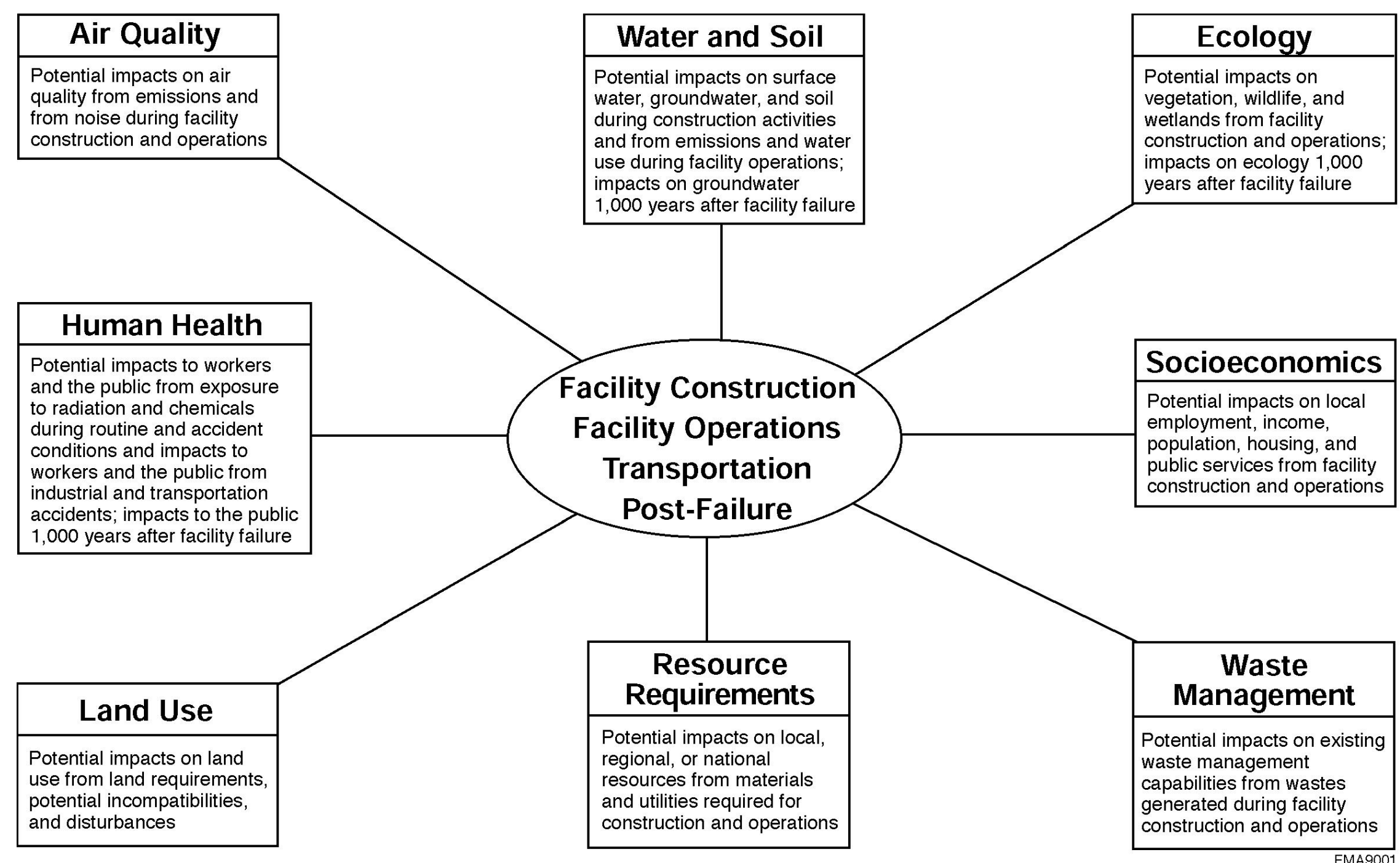

FIGURE 4.1 Areas of Potential Impact Evaluated in the Depleted UF 4 Disposal Analysis 


\section{TABLE 4.2 General Criteria Used to Summarize and Describe the Magnitude of Environmental Impacts}

\begin{tabular}{|c|c|c|c|}
\hline \multirow[b]{2}{*}{ Area of Impact } & \multicolumn{3}{|c|}{ General Criteria Used to Define Descriptor Term } \\
\hline & Negligible to Low & Moderate & Large \\
\hline $\begin{array}{l}\text { Human health and safety } \\
\text { (construction, operations, } \\
\text { transportation) }\end{array}$ & \multicolumn{3}{|c|}{$\begin{array}{l}\text { Human health and safety impacts are provided in terms of the number or degree of health } \\
\text { effects (impacts are not described in terms of negligible to low, moderate, or large) }\end{array}$} \\
\hline Air quality & \multicolumn{3}{|c|}{$\begin{array}{l}\text { Air quality impacts are compared with applicable air standards or guidelines (impacts are not } \\
\text { described in terms of negligible to low, moderate, or large) }\end{array}$} \\
\hline \multicolumn{4}{|l|}{ Surface water } \\
\hline Runoff & $\begin{array}{l}\text { No observable increase in } \\
\text { runoff. }\end{array}$ & $\begin{array}{l}\text { Increased runoff, but } \\
\text { manageable through existing } \\
\text { drainage patterns }\end{array}$ & $\begin{array}{l}\text { Existing drainage patterns } \\
\text { possibly inadequate to } \\
\text { handle increased runoff. }\end{array}$ \\
\hline Floodplains & $\begin{array}{l}\text { No observable change in } \\
\text { existing floodplains }\end{array}$ & $\begin{array}{l}\text { Change in existing } \\
\text { floodplain area of between } \\
1 \% \text { and } 10 \%\end{array}$ & $\begin{array}{l}\text { Change in existing } \\
\text { floodplain area of more than } \\
10 \%\end{array}$ \\
\hline Water quality & \multicolumn{3}{|c|}{$\begin{array}{l}\text { Water quality impacts are compared with applicable water quality standards or guidelines } \\
\text { (impacts are not described in terms of negligible to low, moderate, or large) }\end{array}$} \\
\hline \multicolumn{4}{|l|}{ Groundwater } \\
\hline Recharge & $\begin{array}{l}\text { No observable change in } \\
\text { recharge }\end{array}$ & $\begin{array}{l}\text { Observable change in } \\
\text { volumetric flow of water } \\
\text { reaching the groundwater } \\
\text { aquifer, but less than a } 50 \% \\
\text { change in the existing rate }\end{array}$ & $\begin{array}{l}\text { Change in volumetric flow of } \\
\text { water reaching the } \\
\text { groundwater aquifer of more } \\
\text { than } 50 \%\end{array}$ \\
\hline Depth to groundwater & No observable change & $\begin{array}{l}\text { Change of less than } 10 \% \\
\text { from the current value }\end{array}$ & $\begin{array}{l}\text { Change of more than } 10 \% \\
\text { from the current value }\end{array}$ \\
\hline Water quality & \multicolumn{3}{|c|}{$\begin{array}{l}\text { Water quality impacts are compared with water quality standards or guidelines (impacts are not } \\
\text { described in terms of negligible to low, moderate, or large) }\end{array}$} \\
\hline \multicolumn{4}{|l|}{ Soil } \\
\hline Topography & $\begin{array}{l}\text { No observable change in } \\
\text { elevations }\end{array}$ & $\begin{array}{l}\text { Changes in elevation of less } \\
\text { than } 5 \mathrm{ft} \text { over the area } \\
\text { impacted }\end{array}$ & $\begin{array}{l}\text { Changes in elevation of more } \\
\text { than } 5 \mathrm{ft} \text { over the area } \\
\text { impacted }\end{array}$ \\
\hline Permeability & $\begin{array}{l}\text { No observable change in } \\
\text { infiltration }\end{array}$ & $\begin{array}{l}\text { Changes of less than } 50 \% \text { in } \\
\text { infiltration }\end{array}$ & $\begin{array}{l}\text { Changes of more than } 50 \% \\
\text { in infiltration }\end{array}$ \\
\hline Erosion potential & $\begin{array}{l}\text { No observable change in soil } \\
\text { loss }\end{array}$ & $\begin{array}{l}\text { Changes in soil loss of less } \\
\text { than } 50 \% \text { of existing rate }\end{array}$ & $\begin{array}{l}\text { Changes in soil loss of more } \\
\text { than } 50 \% \text { of the existing rate }\end{array}$ \\
\hline Soil quality & \multicolumn{3}{|c|}{$\begin{array}{l}\text { Soil quality impacts are compared with EPA guidelines (impacts are not described in terms of } \\
\text { negligible to low, moderate, or large) }\end{array}$} \\
\hline
\end{tabular}


TABLE 4.2 (Cont.)

General Criteria Used to Define Descriptor Term

\begin{tabular}{|c|c|c|c|}
\hline Area of Impact & Negligible to Low & Moderate & Large \\
\hline \multicolumn{4}{|l|}{ Socioeconomics } \\
\hline Economic activity & $\begin{array}{l}\text { Less than } 0.1 \text { percentage } \\
\text { point increase in annual } \\
\text { employment growth rate in } \\
\text { the region of influence }\end{array}$ & $\begin{array}{l}\text { Between } 0.1 \text { and } 1.0 \\
\text { percentage point increase in } \\
\text { annual employment growth } \\
\text { rate in the region of } \\
\text { influence }\end{array}$ & $\begin{array}{l}\text { More than } 1.0 \text { percentage } \\
\text { point increase in annual } \\
\text { employment growth rate in } \\
\text { the region of influence }\end{array}$ \\
\hline Population & $\begin{array}{l}\text { Less than } 0.1 \text { percentage } \\
\text { point increase in annual } \\
\text { population growth rate in } \\
\text { the region of influence }\end{array}$ & $\begin{array}{l}\text { Between } 0.1 \text { and } 1.0 \\
\text { percentage point increase in } \\
\text { annual population growth } \\
\text { rate in the region of } \\
\text { influence }\end{array}$ & $\begin{array}{l}\text { More than } 1.0 \text { percentage } \\
\text { point increase in annual } \\
\text { population growth rate in the } \\
\text { region of influence }\end{array}$ \\
\hline Housing & $\begin{array}{l}\text { Less than } 20 \% \text { of vacant } \\
\text { housing units required in the } \\
\text { region of influence }\end{array}$ & $\begin{array}{l}\text { Between } 20 \% \text { and } 50 \% \text { of } \\
\text { vacant housing units } \\
\text { required in the region of } \\
\text { influence }\end{array}$ & $\begin{array}{l}\text { More than } 50 \% \text { of vacant } \\
\text { housing units required in the } \\
\text { region of influence }\end{array}$ \\
\hline Public finance & $\begin{array}{l}\text { Less than } 1 \% \text { increase in } \\
\text { local jurisdictional revenues } \\
\text { and expenditures }\end{array}$ & $\begin{array}{l}\text { Between } 1 \% \text { and } 5 \% \\
\text { increase in local } \\
\text { jurisdictional revenues and } \\
\text { expenditures }\end{array}$ & $\begin{array}{l}\text { More than } 5 \% \text { increase in } \\
\text { local jurisdictional revenues } \\
\text { and expenditures }\end{array}$ \\
\hline Ecology & $\begin{array}{l}\text { No mortality of individual } \\
\text { organisms; no measurable } \\
\text { effects on population or } \\
\text { community parameters; } \\
\text { general guideline of less } \\
\text { than } 10 \text { acres of habitat loss. }\end{array}$ & $\begin{array}{l}\text { Mortality of a small number } \\
\text { of individual organisms; } \\
\text { short-term effects on } \\
\text { population or community } \\
\text { parameters; general } \\
\text { guideline of between } 10 \text { and } \\
100 \text { acres of habitat loss }\end{array}$ & $\begin{array}{l}\text { Mortality of a large number } \\
\text { of individual organisms; } \\
\text { long-term effects on } \\
\text { population or community } \\
\text { parameters; general guideline } \\
\text { of more than } 100 \text { acres of } \\
\text { habitat loss }\end{array}$ \\
\hline Waste management & $\begin{array}{l}\text { Little or no change in waste } \\
\text { facility operations or } \\
\text { capacity requirements (i.e., } \\
\text { less than } 10 \% \text { increased } \\
\text { waste loading or } \\
\text { treatment/disposal capacity } \\
\text { requirements) }\end{array}$ & $\begin{array}{l}\text { Likely increase in capacity } \\
\text { needed at existing facilities } \\
\text { (i.e., increase of } 10 \% \\
\text { to } 100 \% \text { in waste loading or } \\
\text { treatment/disposal capacity } \\
\text { requirements) }\end{array}$ & $\begin{array}{l}\text { Change in waste facility(s) } \\
\text { operations and need for } \\
\text { increased capacity } \\
\text { (i.e., increase of more than } \\
100 \% \text { in waste loading or } \\
\text { treatment/disposal capacity } \\
\text { requirements) }\end{array}$ \\
\hline Resource requirements & $\begin{array}{l}\text { Required quantities of } \\
\text { commonly used materials for } \\
\text { construction and operation } \\
\text { of facilities less than } 5 \% \text { of } \\
\text { existing local capacity; no } \\
\text { use of uncommon materials } \\
\text { such as Monel and Inconel }\end{array}$ & $\begin{array}{l}\text { Required quantities of } \\
\text { commonly used materials for } \\
\text { construction and operation } \\
\text { of facilities more than } 5 \% \text { of } \\
\text { existing local capacity; use } \\
\text { of small amounts of } \\
\text { uncommon materials such as } \\
\text { Monel and Inconel }\end{array}$ & $\begin{array}{l}\text { Required quantities of } \\
\text { commonly used materials for } \\
\text { construction and operation of } \\
\text { facilities more than } 90 \% \text { of } \\
\text { existing local capacity; use } \\
\text { of large amounts of } \\
\text { uncommon materials such as } \\
\text { Monel and Inconel }\end{array}$ \\
\hline
\end{tabular}


TABLE 4.2 (Cont.)

General Criteria Used to Define Descriptor Term

\begin{tabular}{|c|c|c|c|}
\hline Area of Impact & Negligible to Low & Moderate & Large \\
\hline Land use & $\begin{array}{l}\text { No effect on land-use } \\
\text { patterns and traffic flow; } \\
\text { general guideline of land-use } \\
\text { requirement of less than } \\
50 \text { acres }\end{array}$ & $\begin{array}{l}\text { Land-use patterns affected; } \\
\text { land conversion likely; } \\
\text { traffic congestion at } \\
\text { intersections during peak } \\
\text { hours, with change in level- } \\
\text { of-service rating; general } \\
\text { guideline of land-use } \\
\text { requirement of between } 50 \\
\text { and } 200 \text { acres }\end{array}$ & $\begin{array}{l}\text { Land-use patterns affected; } \\
\text { land conversion in conflict } \\
\text { with existing land-use plans } \\
\text { and controls; traffic flow } \\
\text { restricted, with congestion at } \\
\text { intersections, with a high } \\
\text { level-of-service rating; } \\
\text { general guideline of land-use } \\
\text { requirement of more than } \\
200 \text { acres }\end{array}$ \\
\hline Cultural resources & \multicolumn{3}{|c|}{$\begin{array}{l}\text { Cultural resource criteria are not defined because potential impacts could not be ranked (either } \\
\text { they would occur or would not occur) and were considered only in a site-specific context }\end{array}$} \\
\hline Environmental justice & \multicolumn{3}{|c|}{$\begin{array}{l}\text { Environmental justice criteria are not defined because potential impacts could not be ranked } \\
\text { (either they would occur or would not occur) and were considered only in a site-specific } \\
\text { context }\end{array}$} \\
\hline
\end{tabular}




\section{DESCRIPTION OF DISPOSAL FACILITY OPTIONS}

This section provides a brief summary of the different disposal facility options considered in the assessment of depleted $\mathrm{UF}_{4}$ disposal impacts. The information is based on preconceptual design data provided in the $\mathrm{UF}_{4}$ engineering analysis report (Folga and Kier 2001). The engineering analysis report includes much more detailed information, such as descriptions of facility layouts and resource requirements; estimates of effluents, wastes, and emissions; and descriptions of potential accident scenarios.

The three disposal facility options considered are shallow earthen structures (engineered trenches), vaults, and an underground mine. The depleted $\mathrm{UF}_{4}$ would be produced and packaged at a chemical conversion facility and shipped via truck or rail to the disposal site. For each option, it was assumed that the $\mathrm{UF}_{4}$ would be packaged in either 30-gal (110-L) or 55-gal (208-L) drums. Two drum sizes were considered for two reasons: (1) to account for uncertainties in the actual packages that would be used if $\mathrm{UF}_{4}$ were produced for disposal and (2) in recognition of the fact that the relatively large weight of a 55-gal drum loaded with $\mathrm{UF}_{4}$ could pose handling problems at a disposal site. The properties and numbers of drums requiring disposal for the two depleted $\mathrm{UF}_{6}$ inventories considered are summarized in Table 5.1.

A disposal facility for depleted $\mathrm{UF}_{4}$ would consist of a disposal area and two major types of buildings:

1. Warehouse for receiving and shipping products - in which containers shipped to the disposal facility would be temporarily stored and then inspected and transported to a disposal unit. If the inspection were to show that a drum was defective, its contents would be repackaged (i.e., transferred to another drum) before being transferred to a disposal unit from the shipping part of the building. The damaged drums could be crushed and disposed of as LLW, or they could be decontaminated and recycled as scrap metal, if allowed by federal and state regulations at the time.

2. Administration building - that would incorporate all technical and administrative support functions needed to manage the operation of the disposal facility. These functions include security, facility access control, health physics and radiation badges, sanitary facilities, work control and personnel support, internal and external (public relations) communications, spill or emergency response provisions, analytical laboratory, environmental regulatory reporting, and records management for materials control and accountability (MC\&A). 
TABLE 5.1 Estimated Content and Number of UF $_{4}$ Containers Requiring Disposal

\begin{tabular}{ccccc}
\hline & & \multicolumn{2}{c}{ No. of Drums Required } \\
\cline { 3 - 4 } $\begin{array}{c}\text { Drum } \\
\text { Capacity } \\
\text { (gal) }\end{array}$ & $\begin{array}{c}\text { Weight of Drum } \\
\text { Contents } \\
\text { (metric tons) }\end{array}$ & $\begin{array}{c}\text { Amount of Uranium } \\
\text { per Drum } \\
\text { (metric tons) }\end{array}$ & $\begin{array}{c}\text { For 500,000 Metric } \\
\text { Tons of UF }\end{array}$ & $\begin{array}{c}\text { For 630,000 Metric } \\
\text { Tons of UF } \text { H }_{4}\end{array}$ \\
\hline & & & & \\
30 & 0.364 & 0.276 & $1.373 \mathrm{E}+06$ & $1.729 \mathrm{E}+06$ \\
55 & 0.667 & 0.504 & $0.749 \mathrm{E}+06$ & $0.943 \mathrm{E}+06$ \\
\hline
\end{tabular}

Source: Folga and Kier (2001).

These buildings, which would be common to the three disposal options considered, are collectively called the central wasteform facility. The land areas required for the wasteform facility are summarized in Table 5.2.

The unique features of each disposal facility option are briefly described in Sections 5.1 through 5.3 (see Folga and Kier [2001] for details). Land use parameters for each of the three facility options are presented in Table 5.3 for 500,000 metric tons of $U_{4}$ and in Table 5.4 for 630,000 metric tons of $\mathrm{UF}_{4}$.

\subsection{DISPOSAL IN SHALLOW EARTHEN STRUCTURES}

Shallow earthen structures, commonly referred to as engineered trenches, are among the most commonly used forms of LLW disposal, especially in dry climates. Shallow earthen structures would be excavated to a depth of about $26 \mathrm{ft}(8 \mathrm{~m})$, with the length and width determined by site conditions and the annual volume of waste to be disposed of (see Tables 5.3 and 5.4).

Disposal in shallow earthen structures would consist of placing waste on a stable structural pad with barrier walls constructed of compacted clay. Clay would be used because it prevents walls from collapsing or caving in and presents a relatively impermeable barrier to waste migration. The waste containers (i.e., drums) would be tightly stacked three pallets high in the bottom of the structure with forklifts. Any open space between containers would be filled with earth, sand, gravel, or other similar material as each layer of drums was placed.

After the structure would be filled, a 6-ft-thick (2-m-thick) cap composed of engineered fill dirt and clay would be placed on top of it and compacted. The cap would be mounded at least $3 \mathrm{ft}$ $(1 \mathrm{~m})$ above the local grade and sloped to minimize the potential for water infiltration. 
TABLE 5.2 Site Land Parameters at the Wasteform Facility

\begin{tabular}{|c|c|c|c|c|}
\hline \multirow[b]{2}{*}{ Parameter } & \multicolumn{2}{|c|}{500,000 Metric Tons of $\mathrm{UF}_{4}$} & \multicolumn{2}{|c|}{630,000 Metric Tons of $\mathrm{UF}_{4}$} \\
\hline & 30-gal Drums & 55-gal Drums & 30-gal Drums & 55-gal Drums \\
\hline Site land area (ha) & 1.7 & 1.4 & 1.7 & 1.4 \\
\hline Disturbed land area (ha) & 1.7 & 1.4 & 1.7 & 1.4 \\
\hline Total fenced area (ha) & 1.6 & 1.3 & 1.6 & 1.3 \\
\hline Total paved area (ha) & 0.33 & 0.28 & 0.34 & 0.28 \\
\hline Total excavated material $\left(\mathrm{m}^{3}\right)$ & 9,550 & 7,550 & 9,750 & 7,550 \\
\hline
\end{tabular}

TABLE 5.3 Site Land Parameters for Disposal of 500,000 Metric Tons of UF

\begin{tabular}{|c|c|c|c|}
\hline Parameter & $\begin{array}{c}\text { Shallow Earthen } \\
\text { Structure }\end{array}$ & Vaults & Mine \\
\hline \multicolumn{4}{|l|}{ Disposal in 30-gal drums } \\
\hline Site land area (ha) & 20.6 & 25.4 & 236 \\
\hline Disturbed land area (ha) & 18.7 & 25.4 & 236 \\
\hline Total fenced area (ha) & 20.6 & 25.4 & 236 \\
\hline Total paved area (ha) & 0.9 & 3.5 & 12 \\
\hline Total excavated material $\left(\mathrm{m}^{3}\right)$ & $1.29 \mathrm{E}+06$ & $5.71 \mathrm{E}+05$ & $1.22 \mathrm{E}+06$ \\
\hline Facility length (m) & 597 & 552 & 1,586 \\
\hline Facility width (m) & 344 & 460 & 1,560 \\
\hline Underground site land area (ha) & $\mathrm{NA}^{\mathrm{a}}$ & NA & 247 \\
\hline \multicolumn{4}{|l|}{ Disposal in 55-gal drums } \\
\hline Site land area (ha) & 17.4 & 31.6 & 168 \\
\hline Disturbed land area (ha) & 15.7 & 31.6 & 168 \\
\hline Total fenced area (ha) & 17.4 & 31.6 & 168 \\
\hline Total paved area (ha) & 0.8 & 4.4 & 11 \\
\hline Total excavated material $\left(\mathrm{m}^{3}\right)$ & $1.06 \mathrm{E}+06$ & $6.31 \mathrm{E}+05$ & $9.91 \mathrm{E}+05$ \\
\hline Facility length (m) & 506 & 688 & 1,355 \\
\hline Facility width (m) & 344 & 460 & 1,378 \\
\hline Underground site land area (ha) & NA & NA & 187 \\
\hline
\end{tabular}

${ }^{\text {a }} \mathrm{NA}=$ not applicable.

Source: Folga and Kier (2001). 
TABLE 5.4 Site Land Parameters for Disposal of 630,000 Metric Tons of $\mathrm{UF}_{4}$

\begin{tabular}{lccc}
\hline \multicolumn{1}{c}{ Parameter } & Shallow Earthen & & \\
& Structure & Vaults & Mine \\
\hline Disposal in 30-gal drums & & & \\
Site land area (ha) & & 31.6 & 310 \\
Disturbed land area (ha) & 25.5 & 31.6 & 310 \\
Total fenced area (ha) & 23.4 & 31.6 & 310 \\
Total paved area (ha) & 25.5 & 4.4 & 12 \\
Total excavated material (m $\left.{ }^{3}\right)$ & 1.0 & $7.14 \mathrm{E}+05$ & $1.44 \mathrm{E}+06$ \\
Facility length (m) & $1.65 \mathrm{E}+06$ & 688 & 1,740 \\
Facility width (m) & 597 & 460 & 1,782 \\
Underground site land area (ha) & 427 & NA & 310 \\
& NA & & \\
Disposal in 55-gal drums & & 37.9 & 220 \\
Site land area (ha) & & 37.9 & 220 \\
Disturbed land area (ha) & 21.6 & 37.9 & 220 \\
Total fenced area (ha) & 19.7 & 5.2 & 12 \\
Total paved area (ha) & 21.6 & $7.89 \mathrm{E}+05$ & $1.16 \mathrm{E}+06$ \\
Total excavated material (m ${ }^{3}$ ) & 0.9 & 824 & 1,509 \\
Facility length (m) & $1.36 \mathrm{E}+06$ & 460 & 1,548 \\
Facility width (m) & 506 & $\mathrm{NA}$ & 234 \\
Underground site land area (ha) & 427 & $\mathrm{NA}$ & \\
\hline
\end{tabular}

${ }^{\text {a }} \mathrm{NA}=$ not applicable.

Source: Folga and Kier (2001).

\subsection{DISPOSAL IN VAULTS}

Belowground vaults are subsurface reinforced concrete structures. For the preconceptual design basis, the vaults were assumed to be $131 \mathrm{ft}(40 \mathrm{~m})$ wide $\times 266 \mathrm{ft}(81 \mathrm{~m})$ long, with a height of approximately $20 \mathrm{ft}(6 \mathrm{~m})$. The concrete walls were assumed to be $1 \mathrm{ft}(0.3 \mathrm{~m})$ thick, with a floor slab thickness of $2 \mathrm{ft}(0.6 \mathrm{~m})$. The majority of the structure would be located underground, with only the roof area above grade.

Each vault was assumed to be divided into five sections, each section approximately $66 \mathrm{ft}$ $(20 \mathrm{~m})$ long by $26 \mathrm{ft}(8 \mathrm{~m})$ wide and $13 \mathrm{ft}(4 \mathrm{~m})$ tall. As opposed to shallow earthen structures, the walls and floor of a vault would be constructed of reinforced concrete. A crane would be used to 
place drums within each section. Once a vault would be full, any open space between containers would be filled with earth, sand, gravel, or other similar material. A permanent roof slab of reinforced concrete that would completely cover the vault would be installed after all five sections were filled. A cap of engineered fill dirt and clay would be placed on top of the concrete cover and compacted. The cap would be mounded above the local grade and sloped to minimize the potential for water infiltration.

\subsection{DISPOSAL IN A MINE}

An underground mine disposal facility would be a repository for permanent deep geological disposal. A mine disposal facility could either use a previously existing mine or be constructed for the sole purpose of waste disposal. For purposes of comparing options, the conservative assumption of constructing a new mine was assessed for this analysis. A mine disposal facility would consist of surface facilities that would provide space for waste receiving and inspection (the wasteform facility) and of shafts and ramps that would provide access to and ventilation of the underground portion of the repository.

The underground portion would consist of tunnels (called "drifts") for the transport and disposal of waste underground. The dimensions of the drifts were assumed to be $21 \mathrm{ft}(6.5 \mathrm{~m})$ wide $\times 330 \mathrm{ft}(100 \mathrm{~m})$ long and $18 \mathrm{ft}(5 \mathrm{~m})$ high. Waste containers would be placed in drifts, and the drifts would be backfilled with loose material after emplacement. 


\section{IMPACTS OF OPTIONS - OPERATIONAL PHASE}

Potential impacts analyzed for the operational phase of the depleted $\mathrm{UF}_{4}$ disposal facility options included impacts occurring during facility construction and during the period when the waste material would be actively placed into disposal units (20 years for disposal of 500,000 metric tons of $\mathrm{UF}_{4} ; 25$ years for disposal of 630,000 metric tons of $\mathrm{UF}_{4}$ ). The potential environmental impacts during the post-closure period, after the disposal facility would cease operations, are presented in Section 7; transportation impacts are presented in Section 8. The estimated operational impacts are discussed in this section for each area of impact.

The environmental impacts during the operational phase were evaluated on the basis of the information described in the $\mathrm{UF}_{4}$ engineering analysis report (Folga and Kier 2001). The following general assumptions apply to the assessment of impacts:

C Impacts during the operational phase include those from preliminary facility construction and the period when $\mathrm{UF}_{4}$ would be actively placed into disposal units. Construction of disposal units would occur incrementally while waste material was being received.

C Bulk (ungrouted) $\mathrm{UF}_{4}$ would be disposed of directly without significant processing at the disposal facility. Consequently, essentially no $\mathrm{UF}_{4}$ air or water emissions would be associated with normal (nonaccident) operations. Emissions would include dust during construction and exhaust emissions from equipment used during construction and waste emplacement.

C The potential impacts from disposal were analyzed for a generic dry environmental setting. The historical meteorological conditions for five actual dry locations in the southwestern United States were used for dispersion calculations. It was assumed that a disposal facility would be located in a rural area with a population density of 15 persons $/ \mathrm{mi}^{2}\left(6\right.$ persons $\left./ \mathrm{km}^{2}\right)$.

\subsection{HUMAN HEALTH - NORMAL OPERATIONS}

\subsubsection{Radiological Impacts}

Radiological impacts during normal operations of the facility were estimated for involved workers, noninvolved workers, and members of the general public. External radiation resulting from the handling and shipping of uranium materials would be the major source of exposure for involved 
workers. Variations in exposures for the three disposal types considered (shallow earthen structures, vaults, or mine) would be caused by different practices employed for emplacement in the three different types of disposal facilities. Disposal in a mine would require transport of waste containers from the ground surface to the underground cavities, whereas disposal in shallow earthen structures and vaults would require filling and capping efforts to cover the waste containers with dirt, cement, and/or other engineering materials. Variations in the results for 30-gal drums and 55-gal drums would be caused by different dose rates due to different sizes of containers and different numbers of containers to be handled. In general, the average radiation exposure to involved workers would be less than $650 \mathrm{mrem} / \mathrm{yr}$.

Exposures to noninvolved workers and the general public could result if there were releases of uranium compounds to the atmosphere or surface water. However, during normal operations, no releases would be expected (Folga and Kier 2001); therefore, potential exposures would be zero for these two groups of receptors.

The estimated potential radiation exposures for the different disposal options are listed in Table 6.1. The risk of latent cancer fatalities (LCFs) resulting from the exposures presented in Table 6.1 are presented in Table 6.2. The risks presented in Table 6.2 were estimated by multiplying the radiation doses by health risk conversion factors of $4 \times 10^{-4} \mathrm{LCF} /$ person-rem for workers and $5 \times 10^{-4} \mathrm{LCF} /$ person-rem for members of the public. Detailed discussions of the methodology used in the radiological impact analyses are provided in Appendix C of the PEIS (DOE 1999) and Cheng et al. (1997).

\subsubsection{Disposal of 500,000 Metric Tons of $\mathrm{UF}_{4}$}

The estimated radiation exposures to involved workers from disposal of $\mathrm{UF}_{4}$ in 55 -gal drums would be somewhat greater than the radiation exposures from disposal of $\mathrm{UF}_{4}$ in 30-gal drums. Annual collective doses would range from 14 to 18 person-rem/yr for disposal in 30-gal drums and from 16 to 20 person-rem/yr in 55-gal drums. These collective doses would result in less than $1 \times 10^{-2}$ fatalities per year ( 1 additional latent cancer fatality [LCF] in 100 years).

Estimated average worker doses for disposal in 30 gal-drums would range from 260 to $440 \mathrm{mrem} / \mathrm{yr}$. For disposal in 55-gal drums, the average doses would range from $410 \mathrm{mrem} / \mathrm{yr}$ to $650 \mathrm{mrem} / \mathrm{yr}$. Potential exposures of involved workers would be well below the radiation dose limit of 5,000 mrem/yr (Code of Federal Regulations, Title 10, Part 835 [10 CFR Part 835]).

In general, greater radiation exposures would be expected from disposal in a mine than from disposal in shallow earthen structures or vaults. For the latter two disposal technologies, radiation exposures would be about the same. 
TABLE 6.1 Estimated Radiological Doses from Normal Operations under UF $_{4}$ Disposal Options

\begin{tabular}{|c|c|c|c|c|c|c|}
\hline \multirow[b]{3}{*}{ Option/Inventory $^{\mathrm{a}}$} & \multicolumn{6}{|c|}{ Annual Dose to Receptor } \\
\hline & \multicolumn{2}{|c|}{ Involved Worker $^{\mathrm{b}}$} & \multicolumn{2}{|c|}{ Noninvolved Worker ${ }^{\mathrm{c}}$} & \multicolumn{2}{|c|}{ General Public $^{\mathrm{d}}$} \\
\hline & $\begin{array}{c}\text { Average } \\
\text { Individual } \\
\text { Dose (mrem) }\end{array}$ & $\begin{array}{l}\text { Collective } \\
\text { Dose } \\
\text { (person-rem) }\end{array}$ & $\begin{array}{l}\text { MEI Dose } \\
\text { (mrem) }\end{array}$ & $\begin{array}{l}\text { Collective } \\
\text { Dose } \\
\text { (person-rem) }\end{array}$ & $\begin{array}{l}\text { MEI Dose } \\
\text { (mrem) }\end{array}$ & $\begin{array}{c}\text { Collective } \\
\text { Dose } \\
\text { (person-rem) }\end{array}$ \\
\hline \multicolumn{7}{|c|}{ Disposal of 500,000 Metric Tons of $U F_{4}$} \\
\hline \multicolumn{7}{|c|}{ Shallow earthen structure } \\
\hline 30-gal drums & 260 & 14 & 0 & 0 & 0 & 0 \\
\hline 55-gal drums & 410 & 16 & 0 & 0 & 0 & 0 \\
\hline \multicolumn{7}{|l|}{ Vault } \\
\hline 30-gal drums & 260 & 14 & 0 & 0 & 0 & 0 \\
\hline 55-gal drums & 410 & 16 & 0 & 0 & 0 & 0 \\
\hline \multicolumn{7}{|l|}{ Mine } \\
\hline 30-gal drums & 440 & 18 & 0 & 0 & 0 & 0 \\
\hline 55-gal drums & 650 & 20 & 0 & 0 & 0 & 0 \\
\hline \multicolumn{7}{|c|}{ Disposal of 630,000 Metric Tons of $U_{4}$} \\
\hline \multicolumn{7}{|c|}{ Shallow earthen structure } \\
\hline 30-gal drums & 260 & 14 & 0 & 0 & 0 & 0 \\
\hline 55-gal drums & 410 & 16 & 0 & 0 & 0 & 0 \\
\hline \multicolumn{7}{|l|}{ Vault } \\
\hline \multirow{3}{*}{$\begin{array}{l}\text { 30-gal drums } \\
55 \text {-gal drums }\end{array}$} & & & & & & \\
\hline & 260 & 14 & 0 & 0 & 0 & 0 \\
\hline & 410 & 16 & 0 & 0 & 0 & 0 \\
\hline \multicolumn{7}{|l|}{ Mine } \\
\hline 30-gal drums & 440 & 18 & 0 & 0 & 0 & 0 \\
\hline 55-gal drums & 650 & 20 & 0 & 0 & 0 & 0 \\
\hline
\end{tabular}

a Two inventories were considered for each option: 500,000 and 630,000 metric tons of $\mathrm{UF}_{4}$. The first inventory is a result of converting 560,000 metric tons of depleted $\mathrm{UF}_{6}$ that DOE facilities had generated in the past. The second inventory is a result of converting 705,000 metric tons of $\mathrm{UF}_{6}$ that included both the amount DOE generated and the amount USEC generated.

$\mathrm{b}$

Involved workers are those workers directly involved in handling materials. Impacts are presented as average individual dose and collective dose for the worker population. Radiation doses to individual workers would be monitored by a dosimetry program and maintained below applicable standards, such as the DOE administrative control limit of 2,000 mrem/yr (DOE 1992).

c Noninvolved workers are individuals who do not participate in material handling activities, such as employees in the administration building. The number of noninvolved workers ranges from about 15 when disposal is in shallow earthen structures to about 30 when disposal is in vaults or mine cavities.

$\mathrm{d}$ The off-site general public is defined as residents who live within a radius of $50 \mathrm{mi}(80 \mathrm{~km})$ around the disposal site. 
TABLE 6.2 Estimated Latent Cancer Fatality Risks from Normal Operations under UF $_{4}$ Disposal Options

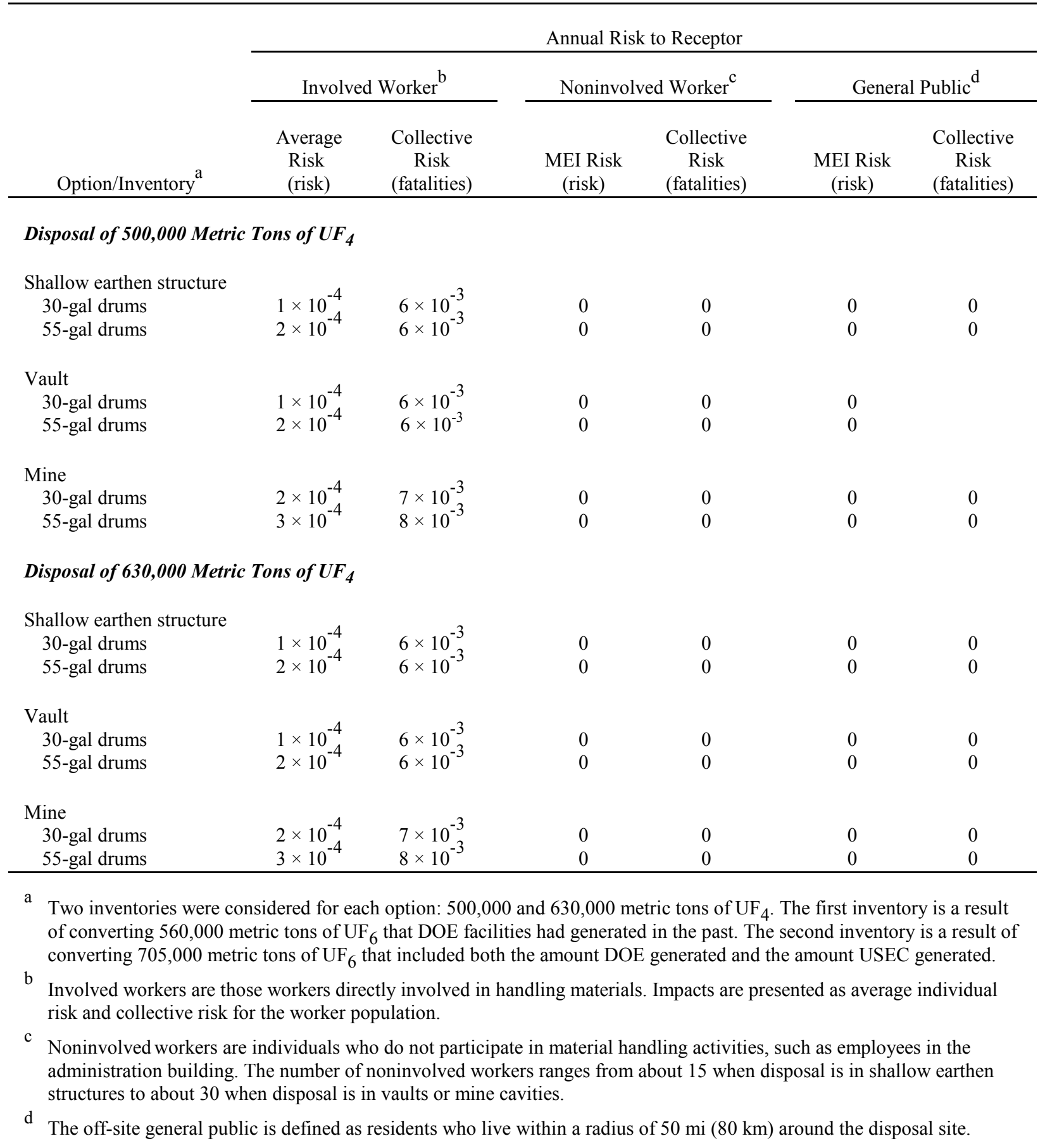




\subsubsection{Disposal of 630,000 Metric Tons of $\mathrm{UF}_{4}$}

Although the inventory of depleted $\mathrm{UF}_{4}$ would increase from 500,000 to 630,000 metric tons, the annual radiation exposures for the receptors considered would be the same as that reported in Section 6.1.1.1. This is because the amount of $U_{4}$ that would be handled per year is assumed to be the same for both cases. However, cumulative exposures from the entire operational period would be greater for disposal of 630,000 metric tons than for disposal of 500,000 metric tons because the operational period would increase from 20 to 25 years.

\subsubsection{Chemical Impacts}

Chemical impacts to the general public, noninvolved workers, and involved workers during the operational phase of the depleted $\mathrm{UF}_{4}$ disposal facility were considered. The only reasonable waste form option considered for depleted $\mathrm{UF}_{4}$ disposal was the ungrouted form, which would be packaged at the conversion facility. Therefore, no chemical impacts to the general public or noninvolved workers would occur at the disposal facility, because airborne emissions would not be expected (Folga and Kier 2001).

For involved workers, the only potential exposures would occur from repackaging the small number of drums that would require it as a result of handling damage. The engineering analysis report (Folga and Kier 2001) states that approximately 25 drums would require repackaging annually, whether disposal was in 30-gal or 55-gal drums. For drum repackaging, electrically powered transfer equipment would pour the contents of the damaged drums into new drums, minimizing worker contact with the drum contents. The transfer equipment would operate in such a way as to keep the operation enclosed and eliminate $U_{4}$ dust generation. Therefore, exposure of involved workers to $\mathrm{UF}_{4}$ dust would be very low and well below occupational exposure standards.

\subsection{HUMAN HEALTH - ACCIDENT CONDITIONS}

A range of accidents covering the spectrum of high-frequency/low-consequence accidents to low-frequency/high-consequence accidents was considered in the $\mathrm{UF}_{4}$ engineering analysis report (Folga and Kier 2001). These accidents are listed in Table 6.3. The following sections present the results for radiological and chemical health impacts of the highest consequence accident in each frequency category considered. Detailed descriptions of the methodology and assumptions used in these calculations are provided in Appendix C of the PEIS and Policastro et al. (1997). 
TABLE 6.3 Accidents Considered under UF $_{4}$ Disposal Options ${ }^{\mathrm{a}}$

\begin{tabular}{|c|c|c|c|c|c|}
\hline $\begin{array}{l}\text { Option/Accident } \\
\text { Scenario }\end{array}$ & Accident Description & $\begin{array}{l}\text { Chemical } \\
\text { Form }\end{array}$ & $\begin{array}{l}\text { Amount } \\
\text { Released } \\
\text { (lb) }\end{array}$ & $\begin{array}{c}\text { Duration } \\
(\mathrm{min})\end{array}$ & $\begin{array}{c}\text { Release } \\
\text { Level }\end{array}$ \\
\hline \multicolumn{6}{|c|}{ Likely Accidents (frequency: 1 or more times in 100 years) } \\
\hline $\begin{array}{l}\text { Mishandling/drop of } \\
\text { drum inside the product } \\
\text { receiving area }\end{array}$ & $\begin{array}{l}\text { A single } \mathrm{UF}_{4} \text { drum is damaged by a forklift and } \\
\text { spills its contents onto the ground inside the } \\
\text { product receiving area. }\end{array}$ & $\mathrm{UF}_{4}$ & $\begin{array}{l}0.000079 \\
(0.00015)\end{array}$ & Puff & Stack \\
\hline $\begin{array}{l}\text { Mishandling/drop of } \\
\text { drum outside the product } \\
\text { receiving area }\end{array}$ & $\begin{array}{l}\text { A single } \mathrm{UF}_{4} \text { drum is damaged by a forklift and } \\
\text { spills its contents outside the product receiving } \\
\text { area. }\end{array}$ & $\mathrm{UF}_{4}$ & $\begin{array}{l}0.079 \\
(0.15)\end{array}$ & Puff & Ground \\
\hline \multicolumn{6}{|c|}{ Unlikely Accidents (frequency: 1 in 100 years to 1 in 10,000 years) } \\
\hline Earthquake & $\begin{array}{l}\text { The product receiving area is damaged during a } \\
\text { design-basis earthquake, resulting in failure of } \\
\text { the structure and confinement systems. }\end{array}$ & $\mathrm{UF}_{4}$ & $\begin{array}{l}275 \\
(275)\end{array}$ & Puff & Ground \\
\hline Tornado & $\begin{array}{l}\text { A major tornado and associated tornado missiles } \\
\text { result in failure of the product receiving area } \\
\text { structures and confinement systems. }\end{array}$ & $\mathrm{UF}_{4}$ & $\begin{array}{c}275 \\
(275)\end{array}$ & Puff & Ground \\
\hline \multicolumn{6}{|c|}{ Extremely Unlikely Accidents (frequency: 1 in 10,000 years to 1 in 1 million years) } \\
\hline \multirow[t]{2}{*}{$\begin{array}{l}\text { Fire/explosion inside the } \\
\text { product receiving and } \\
\text { shipping warehouse }\end{array}$} & $\begin{array}{l}\text { A fire or explosion within the product receiving } \\
\text { and shipping warehouse affects the contents of a } \\
\text { single pallet of four drums. }\end{array}$ & $\mathrm{UO}_{2}$ & $\begin{array}{c}0.0029 \\
(0.0051)\end{array}$ & Puff & Stack \\
\hline & & $\mathrm{HF}$ & 8.64 & & \\
\hline \multicolumn{6}{|c|}{ Incredible Accidents (frequency: less than 1 in 1 million years) } \\
\hline Flood & $\begin{array}{l}\text { The facility would be located at a site that } \\
\text { would preclude severe flooding. }\end{array}$ & $\begin{array}{l}\text { No } \\
\text { release }\end{array}$ & $\mathrm{NA}^{\mathrm{b}}$ & NA & NA \\
\hline \multicolumn{6}{|c|}{$\begin{array}{l}\text { a The amount released is presented for } 30 \text {-gal drums; results for } 55 \text {-gal drums are presented in parentheses. } \\
\text { b NA = not applicable. }\end{array}$} \\
\hline \multicolumn{6}{|c|}{$\begin{array}{l}\text { As they were in the PEIS, accident impacts were calculated for both noninvolved workers } \\
\text { and members of the public within } 50 \mathrm{mi}(80 \mathrm{~km}) \text { of the disposal facility. Chemical and radiological } \\
\text { exposures for involved workers (those within } 100 \mathrm{~m} \text { of the release) under accident conditions would } \\
\text { depend on how rapidly the accident developed, the exact location and response of the workers, the } \\
\text { direction and amount of the release, the physical forces causing or caused by the accident, } \\
\text { meteorological conditions, and characteristics of the room or building if the accident occurred } \\
\text { indoors. Impacts to involved workers under accident conditions would likely be dominated by } \\
\text { physical forces from the accident itself, so that quantitative dose/effect estimates would not be } \\
\text { meaningful. For these reasons, the impacts to involved workers during accidents were not quantified. }\end{array}$} \\
\hline
\end{tabular}


However, it is recognized that injuries and fatalities among involved workers would be possible if an accident did occur.

\subsubsection{Radiological Impacts}

The radiological doses to various receptors for the accidents that would result in the highest dose from each frequency category are listed in Table 6.4. The LCF risks for these accidents are given in Table 6.5. The doses and the risks are presented as ranges (maximum and minimum) because two different meteorological conditions (stable and unstable) were evaluated for each disposal option. The doses and risks presented here were obtained by assuming that the accidents would occur. The results are independent of the overall throughput of the disposal facility because the accidents involve only a limited amount of material that would be at risk. The probability of occurrence for each accident is indicated by the frequency category to which it belongs. For example, accidents in the extremely unlikely category have a probability of occurrence between 1 in 10,000 and 1 in 1 million in any single year. The following conclusions may be drawn from the radiological health impact results:

C No cancer fatalities from radiation doses would be expected from any of the accidents.

C The maximum radiological dose to noninvolved worker and general public maximally exposed individuals (MEIs) (assuming an accident occurred) would be 5.1 rem. This dose is less than the 25-rem dose recommended for assessing the adequacy of protection of public health and safety from potential accidents by the U.S. Nuclear Regulatory Commission (NRC 1994b).

C The overall radiological risk to worker and general public MEI receptors (estimated by multiplying the risk per occurrence [Table 6.5] by the annual probability of occurrence by the number of years of operations) would be much less than 1 for all of the disposal accidents.

\subsubsection{Chemical Impacts}

The accidents assessed in this section were those listed in Table 6.3. The results of the accident consequence modeling in terms of chemical impacts are presented in Tables 6.6 and 6.7. Results are presented as (1) number of people with the potential for adverse effects and (2) number of people with the potential for irreversible adverse effects. The tables present the results for the accident within each frequency category that would affect the largest number of people (total of noninvolved workers and off-site population) (Policastro et al. 1997). The number of workers and 
TABLE 6.4 Estimated Radiological Doses per Accident Occurrence under UF $_{4}$ Disposal Options

\begin{tabular}{|c|c|c|c|c|c|c|c|c|c|}
\hline \multirow[b]{3}{*}{ Option/Accident $^{\mathrm{a}}$} & \multirow[b]{3}{*}{$\begin{array}{l}\text { Frequency } \\
\text { Category }\end{array}$} & \multicolumn{4}{|c|}{ Maximum Dose $^{c}$} & \multicolumn{4}{|c|}{ Minimum Dose $^{c}$} \\
\hline & & \multicolumn{2}{|c|}{ Noninvolved Workers } & \multicolumn{2}{|c|}{ General Public } & \multicolumn{2}{|c|}{ Noninvolved Workers } & \multicolumn{2}{|c|}{ General Public } \\
\hline & & $\begin{array}{c}\text { MEI } \\
(\mathrm{rem})\end{array}$ & $\begin{array}{l}\text { Population } \\
\text { (person-rem) }\end{array}$ & $\begin{array}{c}\text { MEI } \\
(\mathrm{rem})\end{array}$ & $\begin{array}{l}\text { Population } \\
\text { (person-rem) }\end{array}$ & $\begin{array}{l}\text { MEI } \\
(\mathrm{rem})\end{array}$ & $\begin{array}{l}\text { Population } \\
\text { (person-rem) }\end{array}$ & $\begin{array}{c}\text { MEI } \\
(\mathrm{rem})\end{array}$ & $\begin{array}{c}\text { Population } \\
\text { (person-rem) }\end{array}$ \\
\hline \multicolumn{10}{|l|}{ Disposal in 30-gal drums } \\
\hline Mishandling/drop of drum outside & $\mathrm{L}$ & $2.6 \times 10^{-5}$ & $2.3 \times 10^{-6}$ & $8.2 \times 10^{-7}$ & $4.8 \times 10^{-6}$ & $2.6 \times 10^{-5}$ & $2.3 \times 10^{-6}$ & $6.3 \times 10^{-7}$ & $4.8 \times 10^{-6}$ \\
\hline Tornado & $\mathrm{U}$ & 5.1 & $2.2 \times 10^{-1}$ & $3.9 \times 10^{-2}$ & $5.1 \times 10^{-2}$ & $4.7 \times 10^{-1}$ & $3.8 \times 10^{-2}$ & $1.0 \times 10^{-2}$ & $3.1 \times 10^{-2}$ \\
\hline $\begin{array}{l}\text { Fire or explosion inside the product } \\
\text { receiving and shipping warehouse }\end{array}$ & $\mathrm{EU}$ & $9.6 \times 10^{-8}$ & $1.9 \times 10^{-7}$ & $9.9 \times 10^{-8}$ & $3.8 \times 10^{-6}$ & $2.9 \times 10^{-11}$ & $5.4 \times 10^{-11}$ & $4.9 \times 10^{-9}$ & $1.7 \times 10^{-6}$ \\
\hline \multicolumn{10}{|l|}{ Disposal in 55-gal drums } \\
\hline Mishandling/drop of drum outside & $\mathrm{L}$ & $4.8 \times 10^{-5}$ & $4.3 \times 10^{-6}$ & $1.5 \times 10^{-6}$ & $8.9 \times 10^{-6}$ & $4.8 \times 10^{-5}$ & $4.3 \times 10^{-6}$ & $1.2 \times 10^{-6}$ & $8.9 \times 10^{-6}$ \\
\hline Earthquake & $\mathrm{U}$ & 5.1 & $2.2 \times 10^{-1}$ & $3.9 \times 10^{-2}$ & $5.1 \times 10^{-2}$ & $4.7 \times 10^{-1}$ & $3.8 \times 10^{-2}$ & $1.0 \times 10^{-2}$ & $3.1 \times 10^{-2}$ \\
\hline $\begin{array}{l}\text { Fire or explosion inside the product } \\
\text { receiving and shipping warehouse }\end{array}$ & $\mathrm{EU}$ & $1.5 \times 10^{-7}$ & $2.9 \times 10^{-7}$ & $1.5 \times 10^{-7}$ & $5.8 \times 10^{-6}$ & $4.4 \times 10^{-11}$ & $8.3 \times 10^{-11}$ & $7.4 \times 10^{-9}$ & $2.7 \times 10^{-6}$ \\
\hline
\end{tabular}

a The bounding accident chosen to represent each frequency category is the one that would result in the highest dose to the general public MEI. Health impacts in that row represent that accident only and not the range of impacts among accidents in that category. Absence of an accident in a certain frequency category indicates that the accident would not result in a release of radioactive material.

b Accident frequencies: likely $(\mathrm{L})=$ estimated to occur one or more times in 100 years of facility operations ( $\left.>10^{-2} / \mathrm{yr}\right)$; unlikely $(\mathrm{U})=$ estimated to occur between once in 100 years and once in 10,000 years of facility operations $\left(10^{-2}-10^{-4} / \mathrm{yr}\right)$; extremely unlikely $(\mathrm{EU})=$ estimated to occur between once in 10,000 years and once in 1 million years of facility operations $\left(10^{-4}-\right.$ $\left.10^{-6} / \mathrm{yr}\right)$.

c Maximum and minimum doses reflect differences in assumed sites, technologies, and meteorological conditions at the time of the accident. In general, maximum doses would occur under meteorological conditions of F stability with $1 \mathrm{~m} / \mathrm{s}$ wind speed, whereas minimum doses would occur under D stability with $4 \mathrm{~m} / \mathrm{s}$ wind speed. 


\section{TABLE 6.5 Estimated Radiological Health Risks per Accident Occurrence under UF $_{4}$ Disposal Options $^{\mathrm{a}}$}

\begin{tabular}{|c|c|c|c|c|c|c|c|c|c|}
\hline \multirow[b]{3}{*}{ Option/Accident $^{\mathrm{b}}$} & \multirow[b]{3}{*}{$\begin{array}{l}\text { Frequency } \\
\text { Category }\end{array}$} & \multicolumn{4}{|c|}{ Maximum Risk $^{\mathrm{d}}$ (LCF) } & \multicolumn{4}{|c|}{ Minimum Risk $^{\mathrm{d}}$ (LCF) } \\
\hline & & \multicolumn{2}{|c|}{ Noninvolved Workers } & \multicolumn{2}{|c|}{ General Public } & \multicolumn{2}{|c|}{ Noninvolved Workers } & \multicolumn{2}{|c|}{ General Public } \\
\hline & & MEI & Population & MEI & Population & MEI & Population & MEI & Population \\
\hline \multicolumn{10}{|l|}{ Disposal in 30-gal drums } \\
\hline Mishandling/drop of drum outside & $\mathrm{L}$ & $1 \times 10^{-8}$ & $9 \times 10^{-10}$ & $4 \times 10^{-10}$ & $2 \times 10^{-9}$ & $1 \times 10^{-8}$ & $9 \times 10^{-10}$ & $3 \times 10^{-10}$ & $4 \times 10^{-9}$ \\
\hline Tornado & $\mathrm{U}$ & $2 \times 10^{-3}$ & $9 \times 10^{-5}$ & $2 \times 10^{-5}$ & $3 \times 10^{-5}$ & $2 \times 10^{-4}$ & $2 \times 10^{-5}$ & $5 \times 10^{-6}$ & $2 \times 10^{-5}$ \\
\hline $\begin{array}{l}\text { Fire or explosion inside the product } \\
\text { receiving and shipping warehouse }\end{array}$ & $\mathrm{EU}$ & $4 \times 10^{-11}$ & $8 \times 10^{-11}$ & $5 \times 10^{-11}$ & $2 \times 10^{-9}$ & $1 \times 10^{-14}$ & $2 \times 10^{-14}$ & $2 \times 10^{-12}$ & $9 \times 10^{-10}$ \\
\hline \multicolumn{10}{|l|}{ Disposal in 55-gal drums } \\
\hline Mishandling/drop of drum outside & $\mathrm{L}$ & $2 \times 10^{-8}$ & $2 \times 10^{-9}$ & $8 \times 10^{-10}$ & $4 \times 10^{-9}$ & $2 \times 10^{-8}$ & $2 \times 10^{-9}$ & $6 \times 10^{-10}$ & $4 \times 10^{-9}$ \\
\hline Earthquake & $\mathrm{U}$ & $2 \times 10^{-3}$ & $9 \times 10^{-5}$ & $2 \times 10^{-5}$ & $3 \times 10^{-5}$ & $2 \times 10^{-4}$ & $2 \times 10^{-5}$ & $5 \times 10^{-6}$ & $2 \times 10^{-5}$ \\
\hline $\begin{array}{l}\text { Fire or explosion inside the product } \\
\text { receiving and shipping warehouse }\end{array}$ & $\mathrm{EU}$ & $6 \times 10^{-11}$ & $1 \times 10^{-10}$ & $8 \times 10^{-11}$ & $3 \times 10^{-9}$ & $2 \times 10^{-14}$ & $3 \times 10^{-14}$ & $4 \times 10^{-12}$ & $1 \times 10^{-9}$ \\
\hline
\end{tabular}

a Values shown are the consequences if the accident did occur. The risk of an accident is the consequence (LCF) times the estimated frequency times 20 years of operations ( 25 years for disposal of 630,000 metric tons of $\left.U_{4}\right)$. The estimated frequencies are as follows: likely $(\mathrm{L})=0.1$; unlikely $(\mathrm{U})=0.001$; extremely unlikely $(\mathrm{EU})=0.00001$; incredible $(\mathrm{I})=0.000001$

b The bounding accident chosen to represent each frequency category is the one that would result in the highest risk to the general public MEI. Health impacts in that row represent that accident only and not the range of impacts among accidents in that category. Absence of an accident in a certain frequency category indicates that the accident would not result in a release of radioactive material.

c Accident frequencies: likely $(\mathrm{L})=$ estimated to occur one or more times in 100 years of facility operations $\left(>10^{-2} / \mathrm{yr}\right)$; unlikely $(\mathrm{U})=$ estimated to occur between once in 100 years and once in 10,000 years of facility operations $\left(10^{-2}-10^{-4} / \mathrm{yr}\right)$; extremely unlikely $(\mathrm{EU})=$ estimated to occur between once in 10,000 years and once in 1 million years of facility operations $\left(10^{-4}-\right.$ $\left.10^{-6} / \mathrm{yr}\right)$.

d Maximum and minimum risks reflect differences in assumed sites, technologies, and meteorological conditions at the time of the accident. In general, maximum risks would occur under meteorological conditions of F stability with $1 \mathrm{~m} / \mathrm{s}$ wind speed, whereas minimum risks would occur under D stability with $4 \mathrm{~m} / \mathrm{s}$ wind speed. 
TABLE 6.6 Number of Persons with Potential for Adverse Effects from Chemical Exposures from Accidents under UF Disposal Options ${ }^{\mathrm{a}}$

\begin{tabular}{|c|c|c|c|c|c|c|c|c|c|}
\hline \multirow[b]{3}{*}{ Option/Accident ${ }^{\mathrm{b}}$} & \multirow[b]{3}{*}{$\begin{array}{l}\text { Frequency } \\
\text { Category }\end{array}$} & \multicolumn{4}{|c|}{ Maximum Number of Persons ${ }^{\mathrm{d}}$} & \multicolumn{4}{|c|}{ Minimum Number of Persons ${ }^{\mathrm{d}}$} \\
\hline & & \multicolumn{2}{|c|}{ Noninvolved Workers } & \multicolumn{2}{|c|}{ General Public } & \multicolumn{2}{|c|}{ Noninvolved Workers } & \multicolumn{2}{|c|}{ General Public } \\
\hline & & $\mathrm{MEI}^{\mathrm{e}}$ & Population & $\mathrm{MEI}^{\mathrm{e}}$ & Population & $\mathrm{MEI}^{\mathrm{e}}$ & Population & $\mathrm{MEI}^{\mathrm{e}}$ & Population \\
\hline \multicolumn{10}{|l|}{ Disposal as ungrouted $\mathrm{UF}_{4}$} \\
\hline Mishandling/drop of drum outside ${ }^{\mathrm{f}}$ & $\mathrm{L}$ & No & 0 & No & 0 & No & 0 & No & 0 \\
\hline Earthquake & $\mathrm{U}$ & Yes & 2.6 & $\mathrm{Yes}^{\mathrm{g}}$ & 2.5 & Yes & 3.5 & No & 0.4 \\
\hline Fire or explosion inside ${ }^{\mathrm{f}}$ & EU & No & 0 & No & 0 & No & 0 & No & 0 \\
\hline
\end{tabular}

a Values shown are the consequences if the accident did occur. Consequences are the same for disposal in 30-gal drums and disposal in 55 -gal drums. The risk of an accident is the consequence

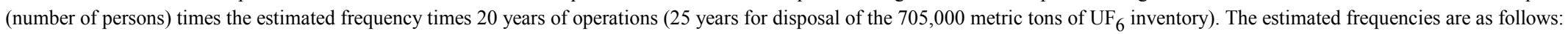
likely $(\mathrm{L})=0.1$; unlikely $(\mathrm{U})=0.001$; extremely unlikely $(\mathrm{EU})=0.00001$; incredible $(\mathrm{I})=0.000001$.

b The bounding accident chosen to represent each frequency category is the one in which the largest number of people (noninvolved workers plus off-site people) would be affected. Health impacts in that row represent that accident only and not the range of impacts among accidents in that category.

c Accident frequencies: likely $(\mathrm{L})=$ estimated to occur one or more times in 100 years of facility operations $\left(>10^{-2} / \mathrm{yr}\right)$; unlikely $(\mathrm{U})=$ estimated to occur between once in 100 years and once in 10,000 years of facility operations $\left(10^{-2}-10^{-4} / \mathrm{yr}\right)$; extremely unlikely $(\mathrm{EU})=$ estimated to occur between once in 10,000 years and once in 1 million years of facility operations $\left(10^{-4}-\right.$ $\left.10^{-6} / \mathrm{yr}\right)$; incredible $(\mathrm{I})=$ estimated to occur less than one time in 1 million years of facility operations $\left(<10^{-6} / \mathrm{yr}\right)$.

$\mathrm{d}$ Maximum and minimum risks reflect different meteorological conditions at the time of the accident. In general, maximum risks would occur under meteorological conditions of $\mathrm{F}$ stability with $1 \mathrm{~m} / \mathrm{s}$ wind speed, whereas minimum risks would occur under D stability with $4 \mathrm{~m} / \mathrm{s}$ wind speed.

e At the MEI location, the determination is either "Yes" or "No" for potential adverse effects to an individual.

$\mathrm{f}$ These accidents would result in the largest plume sizes, although no people would be affected.

$\mathrm{g}$ MEI locations were evaluated at $100 \mathrm{~m}$ from ground-level releases for noninvolved workers and at the location of highest off-site concentration for members of the general public. 
TABLE 6.7 Number of Persons with Potential for Irreversible Adverse Effects from Chemical Exposures from Accidents under $\mathrm{UF}_{4}$ Disposal Options ${ }^{\mathrm{a}}$

\begin{tabular}{|c|c|c|c|c|c|c|c|c|c|}
\hline \multirow[b]{3}{*}{ Option/Accident $^{\mathrm{b}}$} & \multirow[b]{3}{*}{$\begin{array}{l}\text { Frequency } \\
\text { Category }\end{array}$} & \multicolumn{4}{|c|}{ Maximum Number of Persons ${ }^{\mathrm{d}}$} & \multicolumn{4}{|c|}{ Minimum Number of Persons ${ }^{\mathrm{d}}$} \\
\hline & & \multicolumn{2}{|c|}{ Noninvolved Workers } & \multicolumn{2}{|c|}{ General Public } & \multicolumn{2}{|c|}{ Noninvolved Workers } & \multicolumn{2}{|c|}{ General Public } \\
\hline & & $\mathrm{MEI}^{\mathrm{e}}$ & Population & $\mathrm{MEI}^{\mathrm{e}}$ & Population & $\mathrm{MEI}^{\mathrm{e}}$ & Population & $\mathrm{MEI}^{\mathrm{e}}$ & Population \\
\hline \multicolumn{10}{|l|}{ Disposal as Ungrouted $\mathrm{UF}_{4}$} \\
\hline $\begin{array}{l}\text { Mishandling/drop of drum outside } \\
\text { Earthquake }\end{array}$ & $\begin{array}{l}\mathrm{L} \\
\mathrm{U}\end{array}$ & $\begin{array}{l}\text { No } \\
\text { Yes }\end{array}$ & $\begin{array}{c}0 \\
2.3\end{array}$ & $\begin{array}{l}\mathrm{No}_{\mathrm{g}} \\
\mathrm{Yes}^{\mathrm{n}}\end{array}$ & $\begin{array}{c}0 \\
0.8\end{array}$ & $\begin{array}{l}\text { No } \\
\text { Yes }\end{array}$ & $\begin{array}{c}0 \\
2.7\end{array}$ & $\begin{array}{l}\text { No } \\
\text { No }\end{array}$ & $\begin{array}{c}0 \\
0.1\end{array}$ \\
\hline Fire or explosion inside ${ }^{f}$ & EU & No & 0 & No & 0 & No & 0 & No & 0 \\
\hline
\end{tabular}

a Values shown are the consequences if the accident did occur. Consequences are the same for disposal in 30-gal drums and disposal in 55 -gal drums. The risk of an accident is the consequence

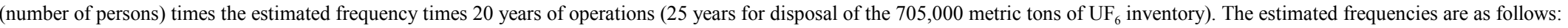
likely $(\mathrm{L})=0.1$; unlikely $(\mathrm{U})=0.001$; extremely unlikely $(\mathrm{EU})=0.00001$; incredible $(\mathrm{I})=0.000001$

b The bounding accident chosen to represent each frequency category is the one in which the largest number of people (noninvolved workers plus off-site people) would be affected. Health impacts in that row represent that accident only and not the range of impacts among accidents in that category.

c Accident frequencies: likely $(\mathrm{L})=$ estimated to occur one or more times in 100 years of facility operations $\left(>10^{-2} / \mathrm{yr}\right)$; unlikely $(\mathrm{U})=$ estimated to occur between once in 100 years and once in 10,000 years of facility operations $\left(10^{-2}-10^{-4} / \mathrm{yr}\right)$; extremely unlikely $(\mathrm{EU})=$ estimated to occur between once in 10,000 years and once in 1 million years of facility operations $\left(10^{-4}-\right.$ $\left.10^{-6} / \mathrm{yr}\right)$; incredible (I) = estimated to occur less than one time in 1 million years of facility operations $\left(<10^{-6} / \mathrm{yr}\right)$.

d Maximum and minimum risks reflect different meteorological conditions at the time of the accident. In general, maximum risks would occur under meteorological conditions of $\mathrm{F}$ stability with $1 \mathrm{~m} / \mathrm{s}$ wind speed, whereas minimum risks would occur under D stability with $4 \mathrm{~m} / \mathrm{s}$ wind speed.

e At the MEI location, the determination is either "Yes" or "No" for potential irreversible adverse effects to an individual.

$\mathrm{f}$ These accidents would result in the largest plume sizes, although no people would be affected.

$\mathrm{g}$ MEI locations were evaluated at $100 \mathrm{~m}$ from ground-level releases for noninvolved workers and at the location of highest off-site concentration for members of the general public. 
number of members of the off-site public represent the impacts if the associated accident was assumed to occur. These impacts may be summarized as follows:

C If the accidents identified in Table 6.3 did occur, the number of persons in the off-site general population with the potential for adverse effects and irreversible adverse effects would range from 0 to 1 (MEI), the maximum corresponding to an earthquake accident. The number of noninvolved workers with the potential for adverse effects would range from 3 to 4 and with the potential for irreversible adverse effects would range from 2 to 3 , the maximums corresponding to an earthquake accident.

C There would be no difference in the consequences from an accident associated with disposal in shallow earthen structures, vaults, or a mine.

C The largest impacts would be caused by an earthquake in the product receiving area. Accidents involving stack emissions would have smaller impacts when compared with accidents involving releases at ground level because of the larger dilution (and lower source terms) involved with the stack emissions.

C For the earthquake accident, the noninvolved worker and the public MEIs could have the potential for both adverse effects and irreversible adverse effects. For all other accidents, the worker and general public MEIs would not have the potential for adverse effects or irreversible adverse effects.

C The maximum risk was computed as the product of the consequence (number of people) times the frequency of occurrence (per year) times the number of years of operations (20 years for disposal of 500,000 metric tons of $\mathrm{UF}_{4}$; 25 years for disposal of 630,000 metric tons of $U_{4}$ ). The results indicated that the maximum risk values would be less than 1 for all accidents. These risk values are conservative because the numbers of people affected were based on assuming meteorological conditions that would result in the maximum reasonably foreseeable plume size (i.e., F stability and $1 \mathrm{~m} / \mathrm{s}$ wind speed).

To aid in the interpretation of accident analysis results, the number of fatalities that could be associated with the estimated potential irreversible adverse effects was estimated. The bounding case accidents shown in Table 6.7 would involve releases of $\mathrm{UF}_{4}$ and potential exposure to uranium compounds. If the accident occurred, exposures would be expected to result in death to $1 \%$ or fewer of the persons experiencing irreversible adverse effects (Policastro et al. 1997). Thus, for noninvolved workers and members of the general public experiencing a range of 0 to 1 irreversible adverse effects, 0 deaths would be expected. 


\subsubsection{Physical Hazards}

The risk of on-the-job fatalities and injuries to all disposal facility workers was calculated by using industry-specific statistics from the Bureau of Labor Statistics, as reported by the National Safety Council (1995). Construction and manufacturing annual fatality and injury rates were used, respectively, for the construction and operational components of the disposal facility activities.

The annual fatality rates used were 15 per 100,000 workers for construction and 4 per 100,000 workers for operations. The annual injury rates used were 5.5 per 100 workers for construction and 5.3 per 100 workers for operations. More recent injury statistics released in 1999 show that fatality and injury rates have decreased slightly (National Safety Council 1999). The updated annual fatality rates would be 13.9 per 100,000 workers for construction and 3.2 per 100,000 workers for operations. The updated annual injury rates would be 4.4 per 100 workers for construction and 4.8 per 100 workers for operations. Because these changes are minor and in order to maintain comparability with the disposal impacts published in the PEIS, the more recent fatality and injury rates were not used for this assessment.

Fatality risks for all options were less than 1 fatality. However, both fatality and injury risks from mining options were two times or more greater than those from shallow earthen structure or vault options. The risks for the mine options were almost twice as large as the risks for the other options, mainly because of the increased risk associated with construction of the large mine that would be needed for the entire inventory of $\mathrm{UF}_{4}$. Mitigation of risks from construction, loading, and closure of mines can be accomplished to a certain extent by instituting safety measures and by conducting thorough safety training programs for personnel.

Estimated fatalities ranged from 0.13 to 0.76 , and injury incidences ranged from 88 to 347 (see Table 6.8). Except for the mine disposal option discussed above, the other options were fairly comparable with respect to predicted fatalities and injuries resulting from physical trauma.

\subsection{AIR QUALITY}

The methodology used to analyze air quality impacts from disposal options is described in Appendix C of the PEIS and Tschanz (1997). Pollutant concentrations were estimated at several distances from the center of the facility because the size and location of the generic disposal facility are uncertain.

Pollutant emissions would result from construction of the wasteform facility and construction of the disposal areas/facilities. The annual emissions of carbon monoxide (CO), hydrocarbons $(\mathrm{HC})$, nitrogen oxides $\left(\mathrm{NO}_{\mathrm{x}}\right)$, sulfur oxides $\left(\mathrm{SO}_{\mathrm{x}}\right)$, and particulate matter $\left(\mathrm{PM}_{10}\right)$ with 
TABLE 6.8 Potential Impacts on Human Health from Physical Hazards from Accidents under $\mathrm{UF}_{4}$ Disposal Options

\begin{tabular}{|c|c|c|c|c|c|c|}
\hline \multirow[b]{3}{*}{$\mathrm{UF}_{4}$ Disposal Option } & \multicolumn{6}{|c|}{ Impacts to All Disposal Facility Workers ${ }^{\mathrm{a}}$} \\
\hline & \multicolumn{3}{|c|}{ Fatality Incidence $^{\mathrm{b}}$} & \multicolumn{3}{|c|}{ Injury Incidence $^{\mathrm{b}}$} \\
\hline & $\begin{array}{c}\text { Wasteform } \\
\text { Facility }\end{array}$ & $\begin{array}{c}\text { Disposal } \\
\text { Facility } \\
\end{array}$ & Total & $\begin{array}{c}\text { Wasteform } \\
\text { Facility }\end{array}$ & $\begin{array}{c}\text { Disposal } \\
\text { Facility }\end{array}$ & Total \\
\hline \multicolumn{7}{|c|}{ 500,000 Metric Tons $U_{4}$ in 30-gal Drums } \\
\hline Shallow earthen structure & 0.07 & 0.09 & 0.16 & 58 & 47 & 105 \\
\hline Vault & 0.07 & 0.18 & 0.25 & 58 & 100 & 158 \\
\hline Mine & 0.07 & 0.59 & 0.66 & 59 & 241 & 300 \\
\hline \multicolumn{7}{|c|}{ 500,000 Metric Tons $U_{4}$ in 55-gal Drums } \\
\hline Shallow earthen structure & 0.06 & 0.07 & 0.13 & 47 & 41 & 88 \\
\hline Vault & 0.06 & 0.17 & 0.23 & 47 & 91 & 138 \\
\hline Mine & 0.06 & 0.53 & 0.59 & 48 & 214 & 262 \\
\hline \multicolumn{7}{|c|}{ 630,000 Metric Tons $U F_{4}$ in 30-gal Drums } \\
\hline Shallow earthen structure & 0.08 & 0.09 & 0.17 & 69 & 54 & 123 \\
\hline Vault & 0.08 & 0.20 & 0.28 & 69 & 118 & 187 \\
\hline Mine & 0.08 & 0.68 & 0.76 & 70 & 277 & 347 \\
\hline \multicolumn{7}{|c|}{ 630,000 Metric Tons $U F_{4}$ in 55-gal Drums } \\
\hline Shallow earthen structure & 0.07 & 0.08 & 0.15 & 57 & 46 & 103 \\
\hline Vault & 0.07 & 0.21 & 0.28 & 57 & 109 & 166 \\
\hline Mine & 0.07 & 0.59 & 0.66 & 59 & 237 & 296 \\
\hline
\end{tabular}

a Values are rounded to two significant figures. All construction and operations workers at the disposal facilities were included in the physical hazard risk calculations.

b Fatality incidence and injury incidence were calculated as the number of full-time-equivalent employees times the annual fatality rate times the number of years. Only injuries involving lost workdays were included. Injury and fatality incidence rates used in the calculations were taken from National Safety Council (1995). 
a mean aerodynamic diameter of $10: \mathrm{m}$ or less, resulting from construction of the wasteform facility and from construction of disposal areas/facilities, are shown in Table 6.9 for disposal of 630,000 metric tons of $\mathrm{UF}_{4}$ in 30-gal drums. The criteria pollutant emissions from construction and operation of the other disposal facilities are related to those in Table 6.9 by the scaling factors listed in Table 6.10. Scaling factors for non- $\mathrm{PM}_{10}\left(\mathrm{CO}, \mathrm{HC}, \mathrm{NO}_{\mathrm{x}}\right)$ and $\mathrm{PM}_{10}$ pollutants are quite different; thus, scaling factors are listed separately in Table 6.10 for these two categories. For example, the $\mathrm{CO}$ emissions from operations involving the disposal of 630,000 metric tons of $U_{4}$ in 30 -gal drums in vaults would be $2.91 \times 1.18$ tons/yr, or 3.43 tons/yr. For the same option, the $\mathrm{PM}_{10}$ emissions would be $0.039 \times 22.7$ tons $/ \mathrm{yr}$, or 0.89 ton $/ \mathrm{yr}$.

The highest concentration increments were estimated on the basis of the highest emissions for each of the construction and operation phases. In general, fugitive dust emissions, resulting from soil excavation and earth-moving activities, would be predominant over other criteria pollutants during the construction period. Potential air quality impacts were estimated on the basis of the highest $\mathrm{PM}_{10}$ emissions (28.60 tons/yr or 25.95 metric tons/yr) from the construction of facilities: mines for disposal of 630,000 metric tons of $U_{4}$ in 30-gal drums (as shown in the upper part of Table 6.11). At a distance of 2,460 $\mathrm{ft}(750 \mathrm{~m})$ from the release point, the maximum 24-hour and annual $\mathrm{PM}_{10}$ concentration increments during construction might be as large as $27 \%$ of the 150-: $\mathrm{g} / \mathrm{m}^{3}$ standard and $13 \%$ of the $50-: \mathrm{g} / \mathrm{m}^{3}$ standard. Concentration increments would be much lower at the potential nearest residence, which is generally far from the site boundaries. The concentration increments for the other criteria pollutants $\left(\mathrm{CO}, \mathrm{SO}_{\mathrm{x}}\right.$, and $\left.\mathrm{NO}_{\mathrm{x}}\right)$ and $\mathrm{HC}$ would be 0.068, 0.32, 0.021, and 0.026 times as large, respectively, as those for $\mathrm{PM}_{10}$. Because the other criteria pollutant concentration increments would be a smaller fraction of their standards than $\mathrm{PM}_{10}$ would be, ambient air quality impacts associated with construction would be minor.

TABLE 6.9 Pollutant Emissions from Construction Activities Associated with Disposal Facilities for 630,000 Metric Tons of $\mathrm{UF}_{4}$ Disposed of in 30-Gallon Drums

\begin{tabular}{|c|c|c|c|c|}
\hline \multirow[b]{2}{*}{ Pollutant } & \multicolumn{4}{|c|}{ Pollutant Emissions from Construction (tons/yr) } \\
\hline & $\begin{array}{l}\text { Wasteform } \\
\text { Facility }\end{array}$ & $\begin{array}{c}\text { Shallow Earthen } \\
\text { Structure }\end{array}$ & Vault & Mine \\
\hline $\mathrm{CO}$ & 0.801 & 2.60 & 1.18 & 1.96 \\
\hline $\mathrm{HC}$ & 0.305 & 0.988 & 0.452 & 0.75 \\
\hline $\mathrm{NO}_{\mathrm{x}}$ & 3.71 & 12.1 & 5.46 & 9.11 \\
\hline $\mathrm{SO}_{\mathrm{x}}$ & 0.244 & 0.792 & 0.363 & 0.60 \\
\hline $\mathrm{PM}_{10}$ & 6.07 & 17.0 & 22.7 & 28.6 \\
\hline
\end{tabular}


TABLE 6.10 Scaling Factors for Criteria Pollutant Emissions from Construction and Operations under $\mathrm{UF}_{4}$ Disposal Options, Relative to Emissions from Construction Associated with Disposal Facilities for 630,00 Metric Tons of $\mathrm{UF}_{4}$ Disposed of in 30-Gallon Drums

\begin{tabular}{|c|c|c|c|c|c|c|}
\hline \multirow{3}{*}{$\begin{array}{r}\mathrm{UF}_{4} \text { Disposal Option } \\
\text { Wasteform facility }\end{array}$} & \multirow{3}{*}{$\begin{array}{c}\begin{array}{c}\text { Inventory } \\
\text { Amount } \\
\text { (metric tons) }\end{array} \\
630,000\end{array}$} & \multirow{3}{*}{$\begin{array}{l}\begin{array}{l}\text { Drum } \\
\text { Size } \\
\text { (gal) }\end{array} \\
30\end{array}$} & \multicolumn{4}{|c|}{ Scaling Factors } \\
\hline & & & \multicolumn{2}{|c|}{ Construction } & \multicolumn{2}{|c|}{ Operations } \\
\hline & & & 1.00 & $(1.00)^{\mathrm{a}}$ & 0.012 & $(5.3 \mathrm{E}-04)^{\mathrm{a}}$ \\
\hline & 630,000 & 55 & 0.76 & $(0.80)$ & 0.011 & $(4.7 \mathrm{E}-04)$ \\
\hline & 500,000 & 30 & 0.98 & $(0.98)$ & 0.012 & $(5.2 \mathrm{E}-04)$ \\
\hline & 500,000 & 55 & 0.76 & $(0.80)$ & 0.011 & $(4.7 \mathrm{E}-04)$ \\
\hline \multirow[t]{4}{*}{ Shallow earthen structure } & 630,000 & 30 & 1.00 & $(1.00)$ & 1.01 & $(0.040)$ \\
\hline & 630,000 & 55 & 0.55 & $(0.84)$ & 0.56 & $(0.022)$ \\
\hline & 500,000 & 30 & 0.99 & $(0.80)$ & 1.01 & $(0.040)$ \\
\hline & 500,000 & 55 & 0.55 & $(0.67)$ & 0.56 & $(0.022)$ \\
\hline \multirow[t]{4}{*}{ Vault } & 630,000 & 30 & 1.00 & $(1.00)$ & 2.91 & $(0.039)$ \\
\hline & 630,000 & 55 & 1.11 & $(1.20)$ & 3.23 & $(0.043)$ \\
\hline & 500,000 & 30 & 1.00 & $(0.80)$ & 2.91 & $(0.039)$ \\
\hline & 500,000 & 55 & 1.11 & $(1.00)$ & 3.23 & $(0.043)$ \\
\hline \multirow[t]{4}{*}{ Mine } & 630,000 & 30 & 1.00 & $(1.00)$ & 0.082 & $(1.17 \mathrm{E}-03)$ \\
\hline & 630,000 & 55 & 0.80 & $(0.81)$ & 0.055 & $(7.83 \mathrm{E}-04)$ \\
\hline & 500,000 & 30 & 0.84 & $(0.85)$ & 0.082 & $(7.41 \mathrm{E}-04)$ \\
\hline & 500,000 & 55 & 0.67 & $(0.69)$ & 0.055 & $(4.97 \mathrm{E}-04)$ \\
\hline
\end{tabular}

${ }^{\text {a }}$ Scaling factors for $\mathrm{PM}_{10}$ are in parentheses.

Except for $\mathrm{NO}_{\mathrm{x}}$ emissions from construction, $\mathrm{NO}_{\mathrm{x}}$ emissions from engine exhaust and building space heating during operations would be the largest of all criteria pollutants. Potential air quality impacts were estimated on the basis of the highest $\mathrm{NO}_{\mathrm{x}}$ emissions (17.62 tons/yr or 15.98 metric tons/yr) from facility operations: vaults for disposal of the original or new inventory in 55-gal drums (as shown in the lower part of Table 6.11). At a distance of 2,460 $\mathrm{ft}(750 \mathrm{~m}$ ) from the release point, the maximum annual $\mathrm{NO}_{\mathrm{x}}$ concentration increments during operation might be as large as $11 \%$ of the $100-: \mathrm{g} / \mathrm{m}^{3}$ standard. The other concentration increments for the criteria pollutant $\left(\mathrm{CO}, \mathrm{SO}_{\mathrm{x}}\right.$, and $\left.\mathrm{PM}_{10}\right)$ and $\mathrm{HC}$ emissions would be $0.22,0.067,0.055$, and 0.083 times as large, respectively, as those for $\mathrm{NO}_{\mathrm{x}}$. Because the impacts of all of these other pollutants relative to their standards would be less than that of $\mathrm{NO}_{\mathrm{x}}$, potential air quality impacts associated with operations would be minor. 
TABLE 6.11 Maximum Concentrations at Three Receptor Distances Resulting from the Construction of a Mine and from the Operation of Vaults

\begin{tabular}{|c|c|c|c|c|c|}
\hline \multirow{2}{*}{$\begin{array}{l}\text { Distance from Emitter to } \\
\text { Receptor }(\mathrm{m}) \text { in Dry Setting }\end{array}$} & \multicolumn{5}{|c|}{ Maximum Concentration $\left(: \mathrm{g} / \mathrm{m}^{3}\right)$} \\
\hline & 1-h Avg & 3-h Avg & 8-h Avg & 24-h Avg & Annual Avg \\
\hline \multicolumn{6}{|l|}{ Construction $^{\mathrm{a}}$} \\
\hline 750 & $470-500$ & $170-200$ & $79-110$ & $32-41$ & $3.8-6.7$ \\
\hline 1,000 & $380-410$ & $150-180$ & $64-85$ & $25-32$ & $2.4-4.4$ \\
\hline 1,500 & $270-280$ & $85-100$ & $41-56$ & $16-20$ & $1.3-2.3$ \\
\hline \multicolumn{6}{|l|}{ Operations $^{\mathrm{b}}$} \\
\hline 750 & $300-490$ & $110-240$ & $50-130$ & $21-55$ & $2.3-11$ \\
\hline 1,000 & $240-370$ & $96-160$ & $42-86$ & $16-33$ & $1.5-4.3$ \\
\hline 1,500 & $170-230$ & $55-81$ & $26-48$ & $10-19$ & $0.76-1.5$ \\
\hline
\end{tabular}

a Based on $\mathrm{PM}_{10}$ emissions from 630,000 metric tons of $\mathrm{UF}_{4}$ in 30-gal drums in a mine.

b Based on $\mathrm{NO}_{\mathrm{x}}$ emissions from 630,000 metric tons of $\mathrm{UF}_{4}$ in 55-gal drums in a vault.

Construction and operations would occur simultaneously for the vault and shallow earthen structure disposal options. (Construction for the mined cavity option would occur before operations.) The combined construction and operations emissions might result in no increase in $\mathrm{PM}_{10}$ emissions and a maximum increase of $38 \%$ in $\mathrm{NO}_{x}$ emissions over maximum operation emissions. Accordingly, the maximum combined construction and operations emissions might result in annual $\mathrm{NO}_{\mathrm{x}}$ concentration increment as large as $15: \mathrm{g} / \mathrm{m}^{3}$ at $2,460 \mathrm{ft}(750 \mathrm{~m})$, which is still well below the $100: \mathrm{g} / \mathrm{m}^{3}$ standard.

Uranium emissions associated with operation of the wasteform facility would be expected to be negligible because there would be no uranium processing under normal conditions.

No quantitative estimate was made of the impacts on ozone conditions. Ozone formation is a regional issue; it is affected by emissions in the entire area around a proposed site. The pollutants most relevant to ozone formation that would result from the disposal of depleted uranium oxide are $\mathrm{HC}$ and $\mathrm{NO}_{\mathrm{x}}$. Later studies that would be conducted after specific technologies and sites have been selected could evaluate the potential effects that the release of those pollutants at a proposed site would have on ozone by comparing those releases with the total emissions of $\mathrm{HC}$ and $\mathrm{NO}_{\mathrm{x}}$ in the surrounding area. Small additional contributions to the regional totals would be unlikely to alter the ozone attainment status of the region. 


\subsection{WATER AND SOIL}

Because this disposal analysis is based on a generic site without a specified location or detailed description, potential impacts to surface water, groundwater and soil could not be assessed on a site-specific basis. Nevertheless, the relative impacts would have the same ranking as that for resource needs. Tables 6.12 through 6.15 summarize the resource requirements for constructing and operating the wasteform facility, shallow earthen structure disposal facility, vault disposal facility, and mined-cavity disposal facility, respectively. Examination of these data indicates that the ranking of facilities (largest to smallest) on the basis of resource requirements would be as follows: mine, vault, shallow earthen structure, and wasteform facility. For each facility, a secondary ranking indicates that the resources required for disposal would be consistently larger for more $\mathrm{UF}_{4}$ (630,000 versus 500,000 metric tons) and smaller containers (30 versus 55 gallons). Therefore, construction and operation of a mine would have the greatest potential for affecting water and soil; construction and operation of the shallow earthen structure would have the least.

If the disposal facility was located on a site that was large compared with the size of the facility, and if it was near a river having a minimum flow that was large compared with annual water use and wastewater discharge, impacts on surface water, groundwater, and soil would be negligible. The reason is because a large site and large river could sufficiently buffer the resources to mitigate the effects produced by construction and operation of the facility.

On the other hand, if the site or the minimum flow in the river was small relative to the resource requirements, impacts would be larger. For example, if the minimum flow in the river was $500 \mathrm{gal} / \mathrm{min}$ or gpm, the net annual water withdrawal for operation of the wasteform facility that disposes of 630,000 metric tons of $\mathrm{UF}_{4}$ in 30 -gal containers would be about $10 \%$ of the flow. The impact of this relative withdrawal could produce moderate impacts to existing floodplains. Similarly, if the mine disposal facility was located on a 1,000-ha (247-acre) site, moderate to large impacts on soil permeability and erosion could result.

More detailed calculations would be performed in the next tier of analyses once a disposal facility option would be selected. In general, impacts could be minimized by constructing and

operating a facility that would have the smallest resource requirements as compared with available resources. 
TABLE 6.12 Environmental Parameters for the Wasteform Facility

Parameter 30-gal Drums $\quad$ 55-gal Drums

Disposal of 500,000 Metric Tons of $\mathrm{UF}_{4}$

$\begin{array}{lcc}\text { Land area (ha) } & 1.7 & 1.4 \\ \text { Disturbed area (ha) } & 1.7 & 1.4 \\ \text { Water } & & \\ \quad \text { Construction }\left(10^{6} \mathrm{~L}\right) & 3.3 & 2.7 \\ \quad \text { Operations }\left(10^{6} \mathrm{~L} / \mathrm{yr}\right) & 0.62 & 0.52 \\ \text { Wastewater } & & \\ \quad \text { Construction }\left(\mathrm{m}^{3}\right) & 4,300 & 3,100 \\ \quad \text { Operations }\left(\mathrm{m}^{3} / \mathrm{yr}\right) & 986 & 859 \\ \text { Excavated material }\left(\mathrm{m}^{3}\right) & 9,550 & 7,550\end{array}$

Disposal of 630,000 Metric Tons of $U F_{4}$

\begin{tabular}{lcc} 
Land area (ha) & 1.7 & 1.4 \\
Disturbed area (ha) & 1.7 & 1.4 \\
Water & & \\
$\quad$ Construction $\left(10^{6} \mathrm{~L}\right)$ & 3.4 & 2.7 \\
$\quad$ Operations $\left(10^{6} \mathrm{~L} / \mathrm{yr}\right)$ & 0.63 & 0.52 \\
Wastewater & & \\
$\quad$ Construction $\left(\mathrm{m}^{3}\right)$ & 4,400 & 3,100 \\
$\quad$ Operations $\left(\mathrm{m}^{3} / \mathrm{yr}\right)$ & 988 & 860 \\
Excavated material $\left(\mathrm{m}^{3}\right)$ & 9,750 & 7,550 \\
\hline
\end{tabular}

\subsection{SOCIOECONOMICS}

The socioeconomic impacts of each $\mathrm{UF}_{4}$ disposal option are discussed here for the peak year of construction and first year of operations. Impacts from each facility are presented separately. However, because the wasteform facility would process waste at the disposal site for each disposal option, the total impact can be determined by summing the impact of the wasteform facility and the impact of each separate facility option.

The impacts from each disposal option for disposal of both the 500,000 and the 630,000 metric tons of $\mathrm{UF}_{4}$ in both container sizes on direct employment and income are shown in Table 6.16. Construction of a wasteform facility for disposal of the 500,000 metric tons of $\mathrm{UF}_{4}$ in 30 -gal containers would create 110 direct jobs and \$4.2 million in direct income. Disposal in 55-gal containers would create 80 direct jobs and \$2.9 million in direct income. Operation of the wasteform 
TABLE 6.13 Environmental Parameters for a Shallow

Earthen Structure

\begin{tabular}{lcc}
\hline \multicolumn{1}{c}{ Parameter } & 30-gal Drums & 55-gal Drums \\
\hline & & \\
Disposal of 500,000 Metric Tons of $\boldsymbol{U F}_{4}$ & \\
& & \\
Land area (ha) & 20.6 & 17.4 \\
Disturbed area (ha) & 18.7 & 15.7 \\
Water & & \\
$\quad$ Construction $\left(10^{6} \mathrm{~L}\right)$ & 0.28 & 0.27 \\
$\quad$ Operations $\left(10^{6} \mathrm{~L} / \mathrm{yr}\right)$ & 0.083 & 0.052 \\
Wastewater & 6,600 & 6,400 \\
$\quad$ Construction $\left(\mathrm{m}^{3}\right)$ & $\mathrm{NA}^{\mathrm{a}}$ & $\mathrm{NA}$ \\
$\quad$ Operations $\left(\mathrm{m}^{3} / \mathrm{yr}\right)$ & $1.29 \times 10^{6}$ & $1.06 \times 10^{6}$ \\
Excavated material $\left(\mathrm{m}^{3}\right)$ &
\end{tabular}

Disposal of 630,000 Metric Tons of $U_{4}$

\begin{tabular}{lcc} 
Land area (ha) & 25.5 & 21.6 \\
Disturbed area (ha) & 23.4 & 19.7 \\
Water & & \\
$\quad$ Construction $\left(10^{6} \mathrm{~L}\right)$ & 0.29 & 0.28 \\
$\quad$ Operations $\left(10^{6} \mathrm{~L} / \mathrm{yr}\right)$ & 0.084 & 0.052 \\
$\quad$ & & \\
Wastewater & 6,900 & 6,600 \\
$\quad$ Construction $\left(\mathrm{m}^{3}\right)$ & $\mathrm{NA}$ & $\mathrm{NA}$ \\
$\quad$ Operations $\left(\mathrm{m}^{3} / \mathrm{yr}\right)$ & $1.65 \times 10^{6}$ & $1.36 \times 10^{6}$ \\
Excavated material $\left(\mathrm{m}^{3}\right)$ & & \\
\hline & &
\end{tabular}

facility would create 40 direct jobs and produce $\$ 2.0$ million in direct income if disposal was in 30 -gal containers, and 40 direct jobs and $\$ 1.8$ million if disposal was in 55-gal containers. For the 630,000 metric tons of $\mathrm{UF}_{4}$, construction of the wasteform facility would create 110 direct jobs and $\$ 4.3$ million in direct income if 30-gal containers were used. If disposal was in 55-gal containers, 80 direct jobs and $\$ 2.9$ million in direct income would be created. Operation of the wasteform facility would create 40 direct jobs and produce $\$ 2.0$ million in direct income if disposal was in 30 -gal containers, and 40 direct jobs and $\$ 1.8$ million if disposal was in 55-gal containers.

Construction of a shallow earthen structure for disposal of 500,000 metric tons of $\mathrm{UF}_{4}$ in 30 -gal containers would create 20 direct jobs and \$0.9 million in direct income. Disposal in 55-gal containers would create 20 direct jobs and $\$ 0.8$ million in direct income. Operation of the shallow 
TABLE 6.14 Environmental Parameters for a Vault

\begin{tabular}{lcc}
\hline \multicolumn{1}{c}{ Parameter } & 30-gal Drums & 55-gal Drum \\
\hline & & \\
Disposal of 500,000 Metric Tons of $\boldsymbol{U F}_{4}$ & \\
& & 31.6 \\
Land area (ha) & 25.4 & 31.6 \\
Disturbed area (ha) & 25.4 & \\
Water & & 65.5 \\
Construction $\left(10^{6} \mathrm{~L}\right)$ & 59.3 & 0.084 \\
Operations $\left(10^{6} \mathrm{~L} / \mathrm{yr}\right)$ & 0.076 & 15,000 \\
Wastewater & 14,000 & $\mathrm{NA}$ \\
Construction $\left(\mathrm{m}^{3}\right)$ & $\mathrm{NA}^{\mathrm{a}}$ & 632,000 \\
Operations $\left(\mathrm{m}^{3} / \mathrm{yr}^{\mathrm{a}}\right)$ & 572,000 & \\
Excavated material $\left(\mathrm{m}^{3}\right)$ & &
\end{tabular}

Disposal of 630,000 Metric Tons of $\mathrm{UF}_{4}$

$\begin{array}{lcc}\text { Land area (ha) } & 31.6 & 37.9 \\ \text { Disturbed area (ha) } & 31.6 & 37.9 \\ \text { Water } & & \\ \quad \text { Construction }\left(10^{6} \mathrm{~L}\right) & 74.1 & 81.9 \\ \quad \text { Operations }\left(10^{6} \mathrm{~L} / \mathrm{yr}\right) & 0.076 & 0.084 \\ \quad & & \\ \quad \text { Wastewater } & 16,000 & 17,000 \\ \quad \text { Construction }\left(\mathrm{m}^{3}\right) & \mathrm{NA} & \mathrm{NA} \\ \quad \text { Operations }\left(\mathrm{m}^{3} / \mathrm{yr}\right) & 714,000 & 790,000 \\ \text { Excavated material }\left(\mathrm{m}^{3}\right) & & \\ & & \end{array}$

earthen structure would create 20 direct jobs and produce $\$ 1.2$ million in direct income if 30 -gal containers were used, and 20 direct jobs and $\$ 0.9$ million if 55-gal containers were used. For 630,000 metric tons of $\mathrm{UF}_{4}$, construction of the shallow earthen structure would create 20 direct jobs and $\$ 0.7$ million in direct income for both container sizes. Operation of the shallow earthen structure would create 20 direct jobs and produce $\$ 1.3$ million in direct income if 30 -gal containers were used, and 20 direct jobs and $\$ 1.0$ million if 55-gal containers were used.

Construction of a vault for disposal of 500,000 metric tons of $\mathrm{UF}_{4}$ in 30-gal containers would create 50 direct jobs and $\$ 1.7$ million in direct income. Disposal in 55-gal containers would create 50 direct jobs and $\$ 1.9$ million in direct income. Operation of the vault facility would create 50 direct jobs and produce $\$ 2.7$ million in direct income if 30 -gal containers were used, and 40 direct 
TABLE 6.15 Environmental Parameters for a Mined Cavity

\begin{tabular}{|c|c|c|}
\hline Parameter & 30-gal Drums & 55-gal Drums \\
\hline \multicolumn{3}{|c|}{ Disposal of 500,000 Metric Tons of $U F_{4}$} \\
\hline Land area (ha) & 236 & 168 \\
\hline Disturbed area (ha) & 236 & 168 \\
\hline \multicolumn{3}{|l|}{ Water } \\
\hline Construction $\left(10^{6} \mathrm{~L}\right)$ & 16.7 & 14.0 \\
\hline Operations $\left(10^{6} \mathrm{~L} / \mathrm{yr}\right)$ & 3.09 & 2.33 \\
\hline \multicolumn{3}{|l|}{ Wastewater } \\
\hline Construction $\left(\mathrm{m}^{3}\right)$ & 58,000 & 52,000 \\
\hline Operations $\left(\mathrm{m}^{3} / \mathrm{yr}\right)$ & $\mathrm{NA}^{\mathrm{a}}$ & NA \\
\hline Excavated material $\left(\mathrm{m}^{3}\right)$ & $1.22 \times 10^{6}$ & 990,000 \\
\hline \multicolumn{3}{|c|}{ Disposal of 630,000 Metric Tons of $\mathrm{UF}_{4}$} \\
\hline Land area (ha) & 310 & 220 \\
\hline Disturbed area (ha) & 310 & 220 \\
\hline \multicolumn{3}{|l|}{ Water } \\
\hline Construction $\left(10^{6} \mathrm{~L}\right)$ & 19.4 & 16.1 \\
\hline Operations $\left(10^{6} \mathrm{~L} / \mathrm{yr}\right)$ & 3.10 & 2.33 \\
\hline \multicolumn{3}{|l|}{ Wastewater } \\
\hline Construction $\left(\mathrm{m}^{3}\right)$ & 66,000 & 57,000 \\
\hline Operations $\left(\mathrm{m}^{3} / \mathrm{yr}\right)$ & NA & NA \\
\hline Excavated material $\left(\mathrm{m}^{3}\right)$ & $1.44 \times 10^{6}$ & $1.16 \times 10^{6}$ \\
\hline
\end{tabular}

jobs and \$2.1 million if 55-gal containers were used. For 630,000 metric tons of $\mathrm{UF}_{4}$, construction of the vault facility would create 40 direct jobs and $\$ 1.6$ million in direct income if 30 -gal containers were used, and 40 direct jobs and $\$ 1.7$ million in direct income if 55-gal containers were used. Operation of the vault facility would create 50 direct jobs and produce $\$ 2.7$ million in direct income if 30-gal containers were used, and 40 direct jobs and \$2.1 million if 55-gal containers were used.

Construction of a mined cavity for disposal of 500,000 metric tons of $\mathrm{UF}_{4}$ in 30 -gal containers would create 760 direct jobs and $\$ 25.5$ million in direct income. Disposal in 55-gal containers would create 680 direct jobs and $\$ 22.8$ million in direct income. Operation of the mined cavity would create 30 direct jobs and produce $\$ 1.7$ million in direct income if 30 -gal containers were used, and 30 direct jobs and $\$ 1.5$ million if 55-gal containers were used. For the 630,000 metric tons of $\mathrm{UF}_{4}$, construction of the mined cavity would create 860 direct jobs and $\$ 28.9$ million in direct 
TABLE 6.16 Socioeconomic Impacts from $\mathrm{UF}_{4}$ Disposal Options

\begin{tabular}{|c|c|c|c|c|c|c|c|c|}
\hline \multirow{3}{*}{$\begin{array}{c}\mathrm{UF}_{4} \text { Disposal Option and } \\
\text { Socioeconomic Parameters }\end{array}$} & \multicolumn{4}{|c|}{$\begin{array}{l}\text { Disposal of 500,000 Metric Tons } \\
\text { of UF } 4 \text { per Phase and Drum Size }\end{array}$} & \multicolumn{4}{|c|}{$\begin{array}{l}\text { Disposal of } 630,000 \text { Metric Tons } \\
\text { of } \mathrm{UF}_{4} \text { per Phase and Drum Size }\end{array}$} \\
\hline & \multicolumn{2}{|c|}{ Construction $^{\mathrm{a}}$} & \multicolumn{2}{|c|}{ Operations $^{\mathrm{b}}$} & \multicolumn{2}{|c|}{ Construction $^{\mathrm{a}}$} & \multicolumn{2}{|c|}{ Operations $^{\mathrm{b}}$} \\
\hline & 30-gal & 55 -gal & 30-gal & 55-gal & 30-gal & 55-gal & 30-gal & 55-gal \\
\hline \multicolumn{9}{|l|}{ Wasteform facility } \\
\hline $\begin{array}{l}\text { Direct employment }{ }^{\mathrm{c}} \\
\text { (no. of persons) }\end{array}$ & 110 & 80 & 40 & 40 & 110 & 80 & 40 & 40 \\
\hline $\begin{array}{l}\text { Direct income } \\
\quad\left(10^{6} \text { year } 2000 \$\right)\end{array}$ & 4.2 & 2.9 & 2.0 & 1.8 & 4.3 & 2.9 & 2.0 & 1.8 \\
\hline \multicolumn{9}{|l|}{ Shallow earthen structure } \\
\hline $\begin{array}{l}\text { Direct employment }{ }^{\mathrm{c}} \\
\text { (no. of persons) }\end{array}$ & 20 & 20 & 20 & 20 & 20 & 20 & 20 & 20 \\
\hline $\begin{array}{l}\text { Direct income } \\
\left(10^{6} \text { year } 2000 \$\right)\end{array}$ & 0.9 & 0.8 & 1.2 & 0.9 & 0.7 & 0.7 & 1.3 & 1.0 \\
\hline \multicolumn{9}{|l|}{ Vault } \\
\hline $\begin{array}{l}\text { Direct employment }{ }^{\mathrm{c}} \\
\text { (no. of persons) }\end{array}$ & 50 & 50 & 50 & 40 & 40 & 40 & 50 & 40 \\
\hline $\begin{array}{l}\text { Direct income } \\
\left(10^{6} \text { year } 2000 \$\right)\end{array}$ & 1.7 & 1.9 & 2.7 & 2.1 & 1.6 & 1.7 & 2.7 & 2.1 \\
\hline \multicolumn{9}{|l|}{ Mine } \\
\hline $\begin{array}{l}\text { Direct employment }{ }^{\mathrm{c}} \\
\text { (no. of persons) }\end{array}$ & 760 & 680 & 30 & 30 & 860 & 740 & 30 & 30 \\
\hline $\begin{array}{l}\text { Direct income } \\
\quad\left(10^{6} \text { year } 2000 \$\right)\end{array}$ & 25.5 & 22.8 & 1.7 & 1.5 & 28.9 & 24.8 & 1.8 & 1.5 \\
\hline
\end{tabular}

a Impacts are from the peak year of construction: Year 3 for the wasteform facility, Year 5 or 6 for the mine. Impacts from constructing the shallow earthen structure or the vault would be identical in each year of the life of the facility, with construction continuing concurrently with waste placement.

b Impacts are for the first year of operation.

c For operations, direct employment includes those persons directly associated with operations, such as chemical operators, foremen, and technicians, plus their line supervision. Clerical and health physics support is also included. The values presented here represent the estimated number of workers for a "greenfield" site, where a new disposal facility would be constructed in support of depleted $\mathrm{UF}_{4}$ disposal. The number of additional workers that would be required at an already existing disposal site would, in general, be less than those shown above. 
income if 30-gal containers were used, and 740 direct jobs and $\$ 24.8$ million in direct income if 55 -gal containers were used. Operation of the mined cavity would create 30 direct jobs and produce $\$ 1.8$ million in direct income if 30 -gal containers were used, and 30 direct jobs and $\$ 1.5$ million if 55 -gal containers were used.

The estimated number of direct jobs created for each option includes those persons directly associated with operations, such as chemical operators, foremen, and technicians, plus their line supervision. Clerical and health physics support is also included. The job estimates presented in this section represent the estimated number of workers for a "greenfield" site, where a new disposal facility would be constructed in support of depleted $\mathrm{UF}_{4}$ disposal. The number of additional workers that would be required at an already existing disposal site would, in general, be less than those presented.

\subsection{ECOLOGY}

Moderate to large impacts on ecological resources could result from constructing a facility for disposal of $\mathrm{UF}_{4}$. Impacts could include the death of individual organisms, habitat loss, or changes in biotic communities.

\subsubsection{Disposal of 500,000 Metric Tons of $\mathrm{UF}_{4}$}

\subsubsection{Shallow Earthen Structure}

Preparing a site for the construction of a facility for the disposal of 500,000 metric tons of $\mathrm{UF}_{4}$ in shallow earthen structures would require the elimination of approximately 46 acres (19 ha) of habitat for disposal in 55-gal drums and approximately 55 acres (22 ha) for disposal in 30-gal drums, including 2.7 to 3.3 acres (1.1 to $1.3 \mathrm{ha}$ ) for paved areas including that area needed for the wasteform facility. Existing vegetation would be destroyed during land clearing activities. The vegetative communities that would be eliminated by site preparation would depend on the actual location of the facility. A considerable period of time might be required to reestablish herbacious vegetation in a dry (less than $10 \mathrm{in} . / \mathrm{yr}[25 \mathrm{~cm} / \mathrm{yr}]$ precipitation) setting such as in the western United States. The loss of 46 to 55 acres (19 to $22 \mathrm{ha}$ ) of undeveloped land would constitute a moderate adverse impact on vegetation. Erosion of exposed soil at construction sites could reduce the effectiveness of restoration efforts and create sedimentation downgradient of the site. The implementation of standard erosion control measures, installation of storm-water retention ponds, and immediate replanting of disturbed areas with native species would help minimize impacts on vegetation. Impacts from facility construction are shown in Table 6.17. 
TABLE 6.17 Impacts on Ecological Resources from $\mathrm{UF}_{4}$ Disposal Facility Construction

\begin{tabular}{|c|c|c|c|}
\hline \multirow[b]{2}{*}{ Resource } & \multicolumn{3}{|c|}{${\text { Impacts from Disposal Facility Construction per } U_{4} \text { Disposal Option }}^{a}$} \\
\hline & Shallow Earthen Structure & Vault & Mine \\
\hline \multicolumn{4}{|c|}{ Disposal of 500,000 Metric Tons of $U_{4}$} \\
\hline Vegetation & $\begin{array}{l}\text { Loss of } 46 \text { to } 55 \text { acres, } \\
\text { moderate adverse impact }\end{array}$ & $\begin{array}{l}\text { Loss of } 67 \text { to } 82 \text { acres, } \\
\text { moderate adverse impact }\end{array}$ & $\begin{array}{l}\text { Loss of } 418 \text { to } 587 \text { acres, } \\
\text { large adverse impact }\end{array}$ \\
\hline Wildlife & $\begin{array}{l}\text { Loss of } 46 \text { to } 55 \text { acres, } \\
\text { moderate adverse impact }\end{array}$ & $\begin{array}{l}\text { Loss of } 67 \text { to } 82 \text { acres, } \\
\text { moderate adverse impact }\end{array}$ & $\begin{array}{l}\text { Loss of } 418 \text { to } 587 \text { acres, } \\
\text { large adverse impact }\end{array}$ \\
\hline Aquatic & $\begin{array}{l}\text { Potential reduction in water } \\
\text { quality, habitat }\end{array}$ & $\begin{array}{l}\text { Potential reduction in water } \\
\text { quality, habitat }\end{array}$ & $\begin{array}{l}\text { Potential reduction in water } \\
\text { quality, habitat }\end{array}$ \\
\hline Wetlands & Potential loss, degradation & Potential loss, degradation & Potential loss, degradation \\
\hline $\begin{array}{l}\text { Protected } \\
\text { species }\end{array}$ & Potential destruction, habitat loss & Potential destruction, habitat loss & Potential destruction, habitat loss \\
\hline \multicolumn{4}{|c|}{ Disposal of 630,000 Metric Tons of $\mathrm{UF}_{4}$} \\
\hline Vegetation & $\begin{array}{l}\text { Loss of } 57 \text { to } 67 \text { acres, } \\
\text { moderate adverse impact }\end{array}$ & $\begin{array}{l}\text { Loss of } 82 \text { to } 97 \text { acres, } \\
\text { moderate to large adverse impact }\end{array}$ & $\begin{array}{l}\text { Loss of } 547 \text { to } 770 \text { acres, } \\
\text { large adverse impact }\end{array}$ \\
\hline Wildlife & $\begin{array}{l}\text { Loss of } 57 \text { to } 67 \text { acres, } \\
\text { moderate adverse impact }\end{array}$ & $\begin{array}{l}\text { Loss of } 82 \text { to } 97 \text { acres, } \\
\text { moderate to large adverse impact }\end{array}$ & $\begin{array}{l}\text { Loss of } 547 \text { to } 770 \text { acres, } \\
\text { large adverse impact }\end{array}$ \\
\hline Aquatic & $\begin{array}{l}\text { Potential reduction in water } \\
\text { quality, habitat }\end{array}$ & $\begin{array}{l}\text { Potential reduction in water } \\
\text { quality, habitat }\end{array}$ & $\begin{array}{l}\text { Potential reduction in water } \\
\text { quality, habitat }\end{array}$ \\
\hline Wetlands & Potential loss, degradation & Potential loss, degradation & Potential loss, degradation \\
\hline $\begin{array}{l}\text { Protected } \\
\text { species }\end{array}$ & Potential destruction, habitat loss & Potential destruction, habitat loss & Potential destruction, habitat loss \\
\hline
\end{tabular}

${ }^{\mathrm{a}}$ All acreages include the wasteform facility.

Wildlife would be disturbed by land clearing, noise, and human presence. Wildlife with restricted mobility, such as burrowing species or juveniles of nesting species, would be destroyed during land clearing activities. Mobile individuals would relocate to adjacent available areas with suitable habitat. Population densities and competition would increase in these areas, potentially reducing the chances of survival or reproductive capacity of displaced individuals. Some wildlife species would probably recolonize replanted areas near the disposal facility after the completion of construction. However, habitat use in the vicinity of the facility might be reduced for some species as a result of the construction of a perimeter fence. In summary, the loss of up to 55 acres ( 22 ha) of habitat as a result of the construction of a facility for disposal of 500,000 metric tons of $\mathrm{UF}_{4}$ in shallow earthen structures would be considered a moderate adverse impact on wildlife. 
Wetlands could be affected by filling or draining during construction. In addition, alteration of surface water runoff patterns, soil compaction, or groundwater flow could occur if the disposal facility was located adjacent to wetland or aquatic habitats. However, impacts would be minimized by maintaining a buffer area around wetlands and aquatic habitats during construction. Unavoidable impacts on wetlands would require a Clean Water Act Section 404 permit, which might stipulate mitigative measures. Additional permitting might be required by state agencies. Depending on the facility location, water withdrawal from surface water or groundwater, as well as wastewater discharge, could potentially alter water levels. These altered levels could, in turn, affect aquatic ecosystems, including wetlands, especially those located along the periphery of these surface water bodies.

Before construction of a disposal facility, a survey for state and federally listed threatened, endangered, or candidate species or species of special concern would be conducted so that impacts on these species could be avoided, if possible. If impacts were unavoidable, appropriate mitigation measures could be developed.

Facility accidents, as discussed in Section 6.3.2, could result in adverse impacts to ecological resources. The affected species and degree of impact would depend on a number of factors, such as location of the accident, season, and meteorological conditions.

\subsubsection{Vault}

The construction and operation of a facility for the disposal of 500,000 metric tons of $U_{4}$ in vaults would generally result in impacts similar to those associated with shallow earthen structures. However, the size of the facility and area of disturbance for vault disposal would be larger. Disposal in vaults would require the disturbance of approximately 67 to 82 acres (27 to $33 \mathrm{ha}$ ) of habitat, depending on the packaging option, including 9.5 to 11.6 acres (3.8 to 4.7 ha) for paved areas, including that area needed for the wasteform facility. This disposal option would elevate the soil surface as a result of the placement of excavated material and reduction in soil permeability. The decrease in soil moisture would make it difficult to reestablish vegetation and would delay the establishment of native plant communities. This disposal option would result in a moderate adverse impact on existing vegetation and wildlife. Reestablishment of native vegetation over such a large area would be especially difficult in a dry setting; a considerable period of time might be required.

\subsubsection{Mine}

The construction and operation of a facility for the disposal of 500,000 metric tons of $\mathrm{UF}_{4}$ in a mine would generally result in impacts similar to those associated with vaults. However, the mine option would require the disturbance of approximately 418 to 587 acres (169 to 238 ha), 
depending on the packaging option, including 27.9 to 30.5 acres (11 to 12 ha) for paved areas, including that area needed for the wasteform facility. This disposal option would elevate the soil surface and reduce soil permeability. The excavated material would primarily consist of rock removed from the drifts and ramps. The consequent decrease in surface soil moisture would make it difficult to reestablish vegetation and would delay the establishment of native plant communities. This disposal option would result in a large adverse impact on existing vegetation and wildlife. Reestablishment of native vegetation over such a large area would be especially difficult in a dry setting; a considerable period of time might be required.

\subsubsection{Disposal of 630,000 Metric Tons of $\mathrm{UF}_{4}$}

The construction and operation of a facility for the disposal of 630,000 metric tons of $\mathrm{UF}_{4}$ would generally result in the same types of impacts as those associated with the disposal of 500,000 metric tons of $\mathrm{UF}_{4}$; however, the facility sizes would be larger. A shallow earthen structure disposal facility for 630,000 metric tons of $\mathrm{UF}_{4}$ would eliminate approximately 57 to 67 acres (23 to $27 \mathrm{ha}$ ) of habitat, including the area for the wasteform facility. This habitat loss would result in a moderate adverse impact on vegetation and wildlife. Disposal in vaults would eliminate approximately 82 to 97 acres ( 33 to 39 ha) of habitat, including the area for the wasteform facility. This loss would result in a moderate to large adverse impact on vegetation and wildlife. A mine disposal facility would disturb approximately 547 to 770 acres (221 to 312 ha) of habitat, including the area for the wasteform facility. This habitat disturbance would result in a large adverse impact on vegetation and wildlife.

\subsection{WASTE MANAGEMENT}

Waste generated during the construction of the disposal facility would be typical of a large construction project. It would include construction debris such as concrete and scrap steel as well as sanitary waste from the labor force. No radioactive wastes would be generated during the construction of the wasteform facility or any of the three proposed disposal facilities because radioactive materials would not be used and the site would be uncontaminated. Construction wastes are listed in Table 6.18. Table 6.19 lists the various hazardous and nonhazardous wastes expected from the different disposal options. Estimates for the original inventory (500,000 metric tons) as well as the larger inventory $\left(630,000\right.$ metric tons) of depleted $\mathrm{UF}_{4}$ are included in the table. The waste generated during the construction of any of the disposal facilities would represent a negligible impact on DOE's waste management capabilities.

Because $\mathrm{UF}_{4}$ forms a corrosive product in the presence of water, it is not suitable for grouting. Depleted $\mathrm{UF}_{4}$ is a Class A waste under NRC's classification scheme. To be classified as a Class A waste, the waste must exhibit structural stability under expected disposal conditions. Such 


\section{TABLE 6.18 Estimated Construction Wastes Generated under UF $_{4}$ Disposal Options}

\begin{tabular}{|c|c|c|c|c|c|c|c|c|}
\hline \multirow[b]{3}{*}{$\begin{array}{c}\mathrm{UF}_{4} \text { Disposal Option } \\
\text { and Waste Type }\end{array}$} & \multicolumn{4}{|c|}{ Disposal of 500,000 Metric Tons of $U_{4}$ per Drum Size } & \multicolumn{4}{|c|}{ Disposal of 630,000 Metric Tons of $U_{4}$ per Drum Size } \\
\hline & \multicolumn{2}{|c|}{ 30-gal } & \multicolumn{2}{|c|}{ 55-gal } & \multicolumn{2}{|c|}{ 30-gal } & \multicolumn{2}{|c|}{55 -gal } \\
\hline & Annual $^{\mathrm{a}}$ & Total & Annual $^{\mathrm{a}}$ & Total & Annual $^{\mathrm{a}}$ & Total & Annual $^{\mathrm{a}}$ & Total \\
\hline \multicolumn{9}{|l|}{ Wasteform facility } \\
\hline Hazardous solids $\left(\mathrm{m}^{3}\right)$ & 4.9 & 14.8 & 3.5 & 10.6 & 4.9 & 15.3 & 3.5 & 10.6 \\
\hline Hazardous liquids $\left(\mathrm{m}^{3}\right)$ & 10.0 & 29.9 & 7.1 & 21.3 & 10.0 & 30.9 & 7.1 & 21.3 \\
\hline \multicolumn{9}{|l|}{ Nonhazardous solids } \\
\hline Concrete $\left(\mathrm{m}^{3}\right)$ & 36.7 & 110 & 30 & 90 & 36.7 & 110 & 30 & 90 \\
\hline Steel (metric tons) & 0.6 & 1.7 & 0.5 & 1.4 & 0.6 & 1.8 & 0.5 & 1.4 \\
\hline Other $\left(\mathrm{m}^{3}\right)$ & 297 & 890 & 230 & 690 & 297 & 920 & 230 & 690 \\
\hline \multicolumn{9}{|l|}{ Nonhazardous liquids } \\
\hline Sanitary $\left(\mathrm{m}^{3}\right)$ & 1,400 & 4,300 & 1,000 & 3,100 & 1,400 & 4,400 & 1,000 & 3,100 \\
\hline Other $\left(\mathrm{m}^{3}\right)$ & 640 & 1,900 & 450 & 1,400 & 640 & 2,000 & 450 & 1,400 \\
\hline \multicolumn{9}{|l|}{ Shallow earthen structure } \\
\hline Hazardous solids $\left(\mathrm{m}^{3}\right)$ & 1.2 & 23 & 1.1 & 22 & 1.0 & 24 & 0.9 & 23 \\
\hline Hazardous liquids $\left(\mathrm{m}^{3}\right)$ & 2.3 & 46 & 2.3 & 45 & 2.0 & 48 & 1.8 & 46 \\
\hline \multicolumn{9}{|l|}{ Nonhazardous solids } \\
\hline Concrete $\left(\mathrm{m}^{3}\right)$ & 0 & 0 & 0 & 0 & 0 & 0 & 0 & 0 \\
\hline Steel (metric tons) & 0 & 0 & 0 & 0 & 0 & 0 & 0 & 0 \\
\hline Other $\left(\mathrm{m}^{3}\right)$ & 0 & 0 & 0 & 0 & 0 & 0 & 0 & 0 \\
\hline \multicolumn{9}{|l|}{ Nonhazardous liquids } \\
\hline Sanitary $\left(\mathrm{m}^{3}\right)$ & 330 & 6,600 & 320 & 6,400 & 274 & 6,900 & 264 & 6,600 \\
\hline Other $\left(\mathrm{m}^{3}\right)$ & 145 & 2,900 & 145 & 2,900 & 124 & 3,100 & 116 & 2,900 \\
\hline \multicolumn{9}{|l|}{ Vault } \\
\hline Hazardous solids $\left(\mathrm{m}^{3}\right)$ & 2.4 & 47 & 2.6 & 51 & 2.2 & 54 & 2.3 & 58 \\
\hline Hazardous liquids $\left(\mathrm{m}^{3}\right)$ & 4.8 & 96 & 5.1 & 102 & 4.4 & 110 & 4.6 & 116 \\
\hline \multicolumn{9}{|l|}{ Nonhazardous solids } \\
\hline Concrete $\left(\mathrm{m}^{3}\right)$ & 133 & 2,660 & 147 & 2,940 & 133 & 3,330 & 147 & 3,680 \\
\hline Steel (metric tons) & 1.1 & 22.0 & 1.2 & 24.5 & 1.1 & 28.0 & 1.2 & 30.5 \\
\hline Other $\left(\mathrm{m}^{3}\right)$ & 1,050 & 21,000 & 1,200 & 24,000 & 1,100 & 27,000 & 1,200 & 29,000 \\
\hline \multicolumn{9}{|l|}{ Nonhazardous liquids } \\
\hline Sanitary $\left(\mathrm{m}^{3}\right)$ & 700 & 14,000 & 750 & 15,000 & 640 & 16,000 & 680 & 17,000 \\
\hline Other $\left(\mathrm{m}^{3}\right)$ & 305 & 6,100 & 325 & 6,500 & 280 & 7,000 & 296 & 7,400 \\
\hline
\end{tabular}




\section{TABLE 6.18 (Cont.)}

\begin{tabular}{|c|c|c|c|c|c|c|c|c|}
\hline \multirow[b]{3}{*}{$\begin{array}{c}\mathrm{UF}_{4} \text { Disposal Option } \\
\text { and Waste Type }\end{array}$} & \multicolumn{4}{|c|}{ Disposal of 500,000 Metric Tons of $U_{4}$ per Drum Size } & \multicolumn{4}{|c|}{ Disposal of 630,000 Metric Tons of $U_{4}$ per Drum Size } \\
\hline & \multicolumn{2}{|c|}{ 30-gal } & \multicolumn{2}{|c|}{ 55-gal } & \multicolumn{2}{|c|}{ 30-gal } & \multicolumn{2}{|c|}{ 55-gal } \\
\hline & Annual $^{\mathrm{a}}$ & Total & Annual $^{\mathrm{a}}$ & Total & Annual $^{\mathrm{a}}$ & Total & Annual $^{\mathrm{a}}$ & Total \\
\hline \multicolumn{9}{|l|}{ Mine } \\
\hline Hazardous solids $\left(\mathrm{m}^{3}\right)$ & 26.7 & 200 & 23.9 & 179 & 30.2 & 227 & 26.0 & 195 \\
\hline Hazardous liquids $\left(\mathrm{m}^{3}\right)$ & 54.2 & 406 & 48.4 & 363 & 61.2 & 459 & 52.6 & 395 \\
\hline \multicolumn{9}{|l|}{ Nonhazardous solids } \\
\hline Concrete $\left(\mathrm{m}^{3}\right)$ & 264 & 1,980 & 219 & 1,640 & 309 & 2,320 & 253 & 1,900 \\
\hline Steel (metric tons) & 2.6 & 19.5 & 2.2 & 16.2 & 3.0 & 22.7 & 2.5 & 18.7 \\
\hline Other $\left(\mathrm{m}^{3}\right)$ & 2,140 & 16,000 & 1,700 & 13,000 & 2,500 & 19,000 & 2,000 & 15,000 \\
\hline \multicolumn{9}{|l|}{ Nonhazardous liquids } \\
\hline Sanitary & 7,700 & 58,000 & 6,900 & 52,000 & 8,800 & 66,000 & 7,600 & 57,000 \\
\hline Other $\left(\mathrm{m}^{3}\right)$ & 3,500 & 26,000 & 3,100 & 23,000 & 3,900 & 29,000 & 3,330 & 25,000 \\
\hline
\end{tabular}

a Construction waste generated in the disposal options for $\mathrm{U}_{3} \mathrm{O}_{8}$ and $\mathrm{UO}_{2}$, as given in Appendix I of the PEIS (DOE 1999), should be compared to the annual generation rates for $\mathrm{UF}_{4}$ disposal options.

Source: Folga and Kier (2001). 


\section{TABLE 6.19 Estimated Annual Radioactive and Nonhazardous Waste Streams from Wasteform Facility Operations}

\begin{tabular}{|c|c|c|c|c|c|}
\hline \multirow[b]{3}{*}{ Waste Stream } & \multirow[b]{3}{*}{ Treatability Category } & \multicolumn{4}{|c|}{ Annual Waste Stream $\left(\mathrm{m}^{3}\right)$ per $\mathrm{UF}_{4}$ Inventory } \\
\hline & & \multicolumn{2}{|c|}{500,000 Metric Tons (20 yr) } & \multicolumn{2}{|c|}{630,000 Metric Tons $(25 \mathrm{yr})$} \\
\hline & & 30-gal Drums & 55-gal Drums & 30-gal Drums & 55-gal Drums \\
\hline Facility waste (product) (LLW) & $\mathrm{NA}^{\mathrm{a}}$ & 7,810 & 7,810 & 7,870 & 7,870 \\
\hline HEPA filters (LLW) & Noncombustible, compactable LLW & 23.8 & 23.8 & 23.8 & 23.8 \\
\hline Damaged drums (LLW) & Surface-contaminated metal LLW & 7.8 & 7.8 & 7.9 & 7.9 \\
\hline Other LLW & Combustible solid LLW & 47.6 & 26.2 & 47.9 & 26.5 \\
\hline Inorganic solutions (LLMW) & Liquid LLMW & 0.26 & 0.18 & 0.26 & 0.18 \\
\hline Nonhazardous (sanitary) wastes & NA & 986 & 859 & 988 & 860 \\
\hline Nonhazardous (other) wastes & NA & 78 & 68 & 78 & 68 \\
\hline Recyclable wastes & NA & 31 & 27 & 31 & 27 \\
\hline
\end{tabular}

a $\mathrm{NA}=$ not applicable.

Source: Folga and Kier (2001). 
stability can be achieved by placing the waste in a strong disposal container such as 30-gal or 55-gal drums. Under these conditions, the wasteform facility would consist of a product receiving, repackaging (where necessary), and shipping warehouse, which would include an administration building. The construction and operation period assumed for the shallow earthen structure and vault disposal facilities is 20 years for the original inventory $(500,000$ metric tons) and 25 years for the new inventory (630,000 metric tons); the construction period assumed is 7.5 years for the mined cavity disposal facility for both inventories, with an operational period of 20 years for the original inventory and 25 years for the new inventory. Table 6.20 lists the drum throughputs at the wasteform facility for each disposal option for both inventories. Table 6.19 lists the annual operational wastes from the wasteform facility for the original inventory (20-yr operation) and the new inventory (25-yr operation).

Estimates of the amount of LLW to be disposed of at DOE waste management disposal facilities depend critically upon the time frame under consideration and the types of waste. The Final Waste Management Programmatic Environmental Impact Statement (WM PEIS; DOE 1997) estimates that 1,060,000 $\mathrm{m}^{3}$ of LLW will be disposed of between 1995 and 2014. This estimate does not include any LLW from environmental restoration activities or facility stabilization activities. A more appropriate value is reported in The 1996 Baseline Environmental Management Report (BEMR) (DOE 1996), which estimates the total amount of LLW for treatment at waste management facilities to be $3,400,000 \mathrm{~m}^{3}$. This estimate is for 75 years and includes contributions from environmental restoration and facility stabilization programs.

The majority of environmental restoration wastes are expected to be generated between 2003 and 2033, approximately the correct time frame to compare with the depleted $\mathrm{UF}_{4}$ wastes. Adjustments must be made to the BEMR estimate to convert treatment volumes into disposal

TABLE 6.20 Variations in Wasteform Facility Operations under $\mathbf{U F}_{4}$ Disposal Options

\begin{tabular}{clcc}
\hline & & \multicolumn{2}{c}{$\begin{array}{c}\text { Annual Throughput Quantity } \\
\text { (no. of drums/yr) per Inventory }\end{array}$} \\
\cline { 3 - 4 } & & & \\
Drum & & 500,000 & 630,000 \\
Size (gal) & UF $_{4}$ Disposal Option & Metric Tons UF 4 & Metric Tons UF $_{4}$ \\
\hline & & & \\
30 & Shallow earthen structure & 68,650 & 69,160 \\
55 & Shallow earthen structure & 37,450 & 37,720 \\
30 & Vault & 68,650 & 69,160 \\
55 & Vault & 37,450 & 37,720 \\
30 & Mine & 183,100 & 230,500 \\
55 & Mine & 99,900 & 125,700 \\
\hline
\end{tabular}


volumes. Both reductions and expansions in volume would occur during waste treatment and grouting, depending on the relative amounts of the different types of waste. On the basis of the WM PEIS analysis (DOE 1997), the BEMR estimate of the disposal volume was adjusted to $4,250,000 \mathrm{~m}^{3}$. The total volumes of LLW from disposal of depleted uranium as $\mathrm{UF}_{4}$ were compared with the total estimated volume of LLW for disposal from all DOE waste management activities (including environmental restoration waste). Disposal volumes were compared as total volume in cubic meters because disposal facilities would not typically have throughput limitations but would be limited in the total volume of waste that they could accept.

For the case of $\mathrm{UF}_{4}$ with a waste volume of $7,810 \mathrm{~m}^{3} / \mathrm{yr}$, the total disposal volume would be $156,000 \mathrm{~m}^{3}\left(7,810 \mathrm{~m}^{3} \times 20\right.$-yr operation). This volume would add about $3.7 \%$ to the estimated total DOE LLW disposal volume of about 4,250,000 $\mathrm{m}^{3}$. Using a similar approach to the new inventory would add about $4.6 \%$ to the estimated total DOE LLW disposal volume. Secondary waste streams of LLW generated in the disposal of $\mathrm{UF}_{4}$ (see Table 6.19) would have only a negligible impact on DOE LLW disposal capabilities. The amount of low-level mixed waste (LLMW) from depleted $\mathrm{UF}_{4}$ disposal added to the total nationwide LLMW load would be negligible (less than 1\%).

Overall, the disposal options would generate appreciable amounts of waste for disposal in DOE facilities. Within the context of the total amount of LLW undergoing disposal in DOE facilities, these wastes would have a small impact on DOE's total waste management disposal capabilities.

\subsection{RESOURCE REQUIREMENTS}

Resource requirements for the disposal options were estimated for construction and operations. The materials required for monitoring groundwater and disposal cell performance would be expected to be minor.

Materials and utilities required for construction and operation of the shallow earthen structure, vault, and mine options are listed in Tables 6.21 to 6.29. In general, the amounts of resources needed are directly related to the volume of waste to be disposed of. The total quantities of commonly used construction materials needed are not expected to be significant and would be comparable to those needed to build a multistory building. No specialty materials (e.g., Monel or Inconel) are projected to be needed for either construction or operations.

Significant quantities of electricity could be required during construction of the mine since

most of the construction equipment is powered by electricity to avoid polluting the air in the underground work area. Similarly, the annual amount of electricity consumed during underground operations would be greater than the amount consumed in the other disposal facility options. 
TABLE 6.21 Materials and Resources Required during Construction of Shallow Earthen Structure Disposal Facility ${ }^{a}$

\begin{tabular}{|c|c|c|c|c|}
\hline \multirow[b]{2}{*}{ Item } & \multicolumn{2}{|c|}{ 30-gal Drums } & \multicolumn{2}{|c|}{ 55-gal Drums } \\
\hline & Annual & Total $^{\mathrm{a}}$ & Annual & Total $^{\mathrm{a}}$ \\
\hline \multicolumn{5}{|c|}{ 500,000 Metric Tons of $U F_{4}$} \\
\hline Water $\left(10^{6} \mathrm{~L}\right)$ & 0.014 & 0.28 & 0.014 & 0.27 \\
\hline Excavated material $\left(\mathrm{m}^{3}\right)$ & $6.44 \mathrm{E}+04$ & $1.29 \mathrm{E}+06$ & $5.32 \mathrm{E}+04$ & $1.06 \mathrm{E}+06$ \\
\hline Clay $\left(\mathrm{m}^{3}\right)$ & 437 & 8,740 & 392 & 7,840 \\
\hline Sand $\left(\mathrm{m}^{3}\right)$ & 2,910 & $5.83 \mathrm{E}+04$ & 2,340 & $4.69 \mathrm{E}+04$ \\
\hline Gravel (metric tons) & 122 & 2,440 & 99 & 1,970 \\
\hline Electricity (MWh) & 220 & 4,410 & 185 & 3,700 \\
\hline Diesel fuel (L) & $5.68 \mathrm{E}+04$ & $1.14 \mathrm{E}+06$ & $4.69 \mathrm{E}+04$ & $9.38 \mathrm{E}+05$ \\
\hline \multicolumn{5}{|c|}{630,000 Metric Tons of $U F_{4}$} \\
\hline Water $\left(10^{6} \mathrm{~L}\right)$ & 0.12 & 0.29 & 0.011 & 0.28 \\
\hline Excavated material $\left(\mathrm{m}^{3}\right)$ & $6.58 \mathrm{E}+04$ & $1.65 \mathrm{E}+06$ & $5.44 \mathrm{E}+04$ & $1.36 \mathrm{E}+06$ \\
\hline Clay $\left(\mathrm{m}^{3}\right)$ & 452 & 11,300 & 406 & $1.01 \mathrm{E}+04$ \\
\hline Sand $\left(\mathrm{m}^{3}\right)$ & 3,060 & $7.65 \mathrm{E}+04$ & 2,480 & $6.20 \mathrm{E}+04$ \\
\hline Gravel (metric tons) & 128 & 3,200 & 104 & 2,600 \\
\hline Electricity (MWh) & 222 & 5,560 & 186 & 4,640 \\
\hline Diesel fuel (L) & $5.82 \mathrm{E}+04$ & $1.45 \mathrm{E}+06$ & $4.81 \mathrm{E}+04$ & $1.20 \mathrm{E}+06$ \\
\hline
\end{tabular}

a Totals are for 20 years of operations for 500,000 metric tons of $\mathrm{UF}_{4}$ and 25 years of operations for 630,000 metric tons of $\mathrm{UF}_{4}$.

TABLE 6.22 Resources Required during Operations of Shallow Earthen Structure Disposal Facility

\begin{tabular}{|c|c|c|c|c|}
\hline \multirow[b]{2}{*}{ Item } & \multicolumn{2}{|c|}{ 30-gal Drums } & \multicolumn{2}{|c|}{ 55-gal Drums } \\
\hline & Annual & Total $^{\mathrm{a}}$ & Annual & Total $^{\mathrm{a}}$ \\
\hline \multicolumn{5}{|c|}{ 500,000 Metric Tons of $U F_{4}$} \\
\hline Water $\left(10^{6} \mathrm{~L}\right)$ & 0.083 & 1.66 & 0.052 & 1.04 \\
\hline Electricity (MWh) & 1,030 & $2.06 \mathrm{E}+04$ & 762 & $1.52 \mathrm{E}+04$ \\
\hline Diesel fuel (L) & $1.48 \mathrm{E}+05$ & $2.97 \mathrm{E}+06$ & $8.21 \mathrm{E}+04$ & $1.64 \mathrm{E}+06$ \\
\hline \multicolumn{5}{|c|}{ 630,000 Metric Tons of $U F_{4}$} \\
\hline Water $\left(10^{6} \mathrm{~L}\right)$ & 0.084 & 2.09 & 0.052 & 1.31 \\
\hline Electricity (MWh) & 1,030 & $2.58 \mathrm{E}+04$ & 765 & $1.91 \mathrm{E}+04$ \\
\hline Diesel fuel (L) & $1.49 \mathrm{E}+05$ & $3.73 \mathrm{E}+06$ & $8.26 \mathrm{E}+04$ & $2.07 \mathrm{E}+06$ \\
\hline
\end{tabular}

a Totals are for 20 years of operations for 500,000 metric tons of $\mathrm{UF}_{4}$ and 25 years of operations for 630,000 metric tons of $\mathrm{UF}_{4}$. 
TABLE 6.23 Materials and Resources Required during Construction of Vault Disposal Facility

\begin{tabular}{|c|c|c|c|c|c|}
\hline \multirow[b]{2}{*}{ Item } & \multirow[b]{2}{*}{ Per Vault } & \multicolumn{2}{|c|}{ 30-gal Drums } & \multicolumn{2}{|c|}{ 55-gal Drums } \\
\hline & & Annual & Total $^{\mathrm{a}}$ & Annual & Total $^{\mathrm{a}}$ \\
\hline \multicolumn{6}{|c|}{500,000 Metric Tons of $U F_{4}$} \\
\hline Number of vaults & 1 & 3.8 & 76 & 4.2 & 84 \\
\hline Concrete Redi-Mix $\left(\mathrm{m}^{3}\right)$ & 1,750 & 6,650 & 133,000 & 7,350 & 147,000 \\
\hline Gravel (metric tons) & 910 & 3,460 & 69,200 & 3,820 & 76,400 \\
\hline Liner $\left(m^{2}\right)$ & 2,220 & 8,440 & 168,700 & 9,320 & 186,500 \\
\hline Steel (metric tons) & 58.5 & 220 & 4,400 & 250 & 4,900 \\
\hline Water $\left(10^{6} \mathrm{~L}\right)$ & 0.78 & 2.96 & 59.3 & 3.28 & 65.5 \\
\hline Excavated material $\left(\mathrm{m}^{3}\right)$ & 7,520 & 28,600 & 572,000 & 31,600 & 632,000 \\
\hline Electricity $(\mathrm{kWh})$ & 12,500 & 47,500 & 950,000 & 52,500 & $1,050,000$ \\
\hline Diesel fuel (L) & 17,800 & 67,600 & $1,353,000$ & 74,800 & $1,495,000$ \\
\hline \multicolumn{6}{|c|}{ 630,000 Metric Tons of $U F_{4}$} \\
\hline Number of vaults & 1 & 3.8 & 95 & 4.2 & 105 \\
\hline Concrete Redi-Mix $\left(\mathrm{m}^{3}\right)$ & 1,750 & 6,650 & $1.66 \mathrm{E}+05$ & 7,350 & $1.84 \mathrm{E}+05$ \\
\hline Gravel (metric tons) & 910 & 3,460 & $8.65 \mathrm{E}+04$ & 3,820 & $9.56 \mathrm{E}+04$ \\
\hline $\operatorname{Liner}\left(\mathrm{m}^{2}\right)$ & 2,220 & 8,440 & $2.11 \mathrm{E}+05$ & 9,320 & $2.33 \mathrm{E}+05$ \\
\hline Steel (metric tons) & 58.5 & 58.5 & 5,600 & 250 & 6,100 \\
\hline Water $\left(10^{6} \mathrm{~L}\right)$ & 0.78 & 2.96 & 74.1 & 3.28 & 81.9 \\
\hline Excavated material $\left(\mathrm{m}^{3}\right)$ & 7,520 & $2.86 \mathrm{E}+04$ & $7.14 \mathrm{E}+05$ & $3.16 \mathrm{E}+04$ & $7.90 \mathrm{E}+05$ \\
\hline Electricity $(\mathrm{kWh})$ & $1.25 \mathrm{E}+04$ & $4.75 \mathrm{E}+04$ & $1.19 \mathrm{E}+06$ & $5.25 \mathrm{E}+04$ & $1.31 \mathrm{E}+06$ \\
\hline Diesel fuel (L) & $1.78 \mathrm{E}+04$ & $6.76 \mathrm{E}+04$ & $1.69 \mathrm{E}+06$ & $7.48 \mathrm{E}+04$ & $1.87 \mathrm{E}+06$ \\
\hline
\end{tabular}

TABLE 6.24 Resources Required during Operations of Vault Disposal Facility

\begin{tabular}{|c|c|c|c|c|c|c|}
\hline \multirow[b]{2}{*}{ Item } & \multicolumn{3}{|c|}{ 30-gal Drums } & \multicolumn{3}{|c|}{ 55-gal Drums } \\
\hline & Per Vault & Annual & Total $^{\mathrm{a}}$ & Per Vault & Annual & Total $^{\mathrm{a}}$ \\
\hline \multicolumn{7}{|c|}{ 500,000 Metric Tons of $U F_{4}$} \\
\hline Number of vaults & 1 & 3.8 & 76 & 1 & 4.2 & 84 \\
\hline Water $\left(10^{6} \mathrm{~L}\right)$ & 0.02 & 0.076 & 1.52 & 0.02 & 0.084 & 1.68 \\
\hline Electricity (kWh) & 328 & 1,250 & $2.49 \mathrm{E}+04$ & 328 & 1,380 & $2.76 \mathrm{E}+04$ \\
\hline Diesel fuel (L) & $5.11 \mathrm{E}+04$ & $1.94 \mathrm{E}+05$ & $3.88 \mathrm{E}+06$ & $5.11 \mathrm{E}+04$ & $2.15 \mathrm{E}+05$ & $4.29 \mathrm{E}+06$ \\
\hline \multicolumn{7}{|c|}{ 630,000 Metric Tons of $U F_{4}$} \\
\hline Number of vaults & 1 & 3.8 & 95 & 1 & 4.2 & 105 \\
\hline Water $\left(10^{6} \mathrm{~L}\right)$ & 0.02 & 0.076 & 1.9 & 0.02 & 0.084 & 2.1 \\
\hline Electricity (kWh) & 328 & 1,250 & $3.12 \mathrm{E}+04$ & 328 & 1,380 & $3.44 \mathrm{E}+04$ \\
\hline Diesel fuel (L) & $5.11 \mathrm{E}+04$ & $1.94 \mathrm{E}+05$ & $4.85 \mathrm{E}+06$ & $5.11 \mathrm{E}+04$ & $2.15 \mathrm{E}+05$ & $5.37 \mathrm{E}+06$ \\
\hline
\end{tabular}


TABLE 6.25 Total Materials and Resources

Required during Construction of Mined

Cavity Facility ${ }^{\mathrm{a}}$

\begin{tabular}{|c|c|c|}
\hline Item & $\begin{array}{l}30 \text {-gal } \\
\text { Drums }\end{array}$ & $\begin{array}{l}55 \text {-gal } \\
\text { Drums }\end{array}$ \\
\hline \multicolumn{3}{|c|}{ 500,000 Metric Tons of $U F_{4}$} \\
\hline Water $\left(10^{6} \mathrm{~L}\right)$ & 16.7 & 14.0 \\
\hline Concrete Redi-Mix $\left(\mathrm{m}^{3}\right)$ & $9.90 \mathrm{E}+04$ & $8.20 \mathrm{E}+04$ \\
\hline Steel (metric tons) & 3,890 & 3,230 \\
\hline Electricity (GWh) & 5,760 & 4,810 \\
\hline Diesel fuel (L) & $7.16 \mathrm{E}+05$ & $5.83 \mathrm{E}+05$ \\
\hline Excavated material $\left(\mathrm{m}^{3}\right)$ & $1.22 \mathrm{E}+06$ & $9.90 \mathrm{E}+05$ \\
\hline \multicolumn{3}{|c|}{ 630,000 Metric Tons of $U F_{4}$} \\
\hline Water $\left(10^{6} \mathrm{~L}\right)$ & 19.4 & 16.1 \\
\hline Concrete Redi-Mix $\left(\mathrm{m}^{3}\right)$ & $1.16 \mathrm{E}+05$ & $9.50 \mathrm{E}+04$ \\
\hline Steel (metric tons) & 4,540 & 3,740 \\
\hline Electricity (GWh) & 6,670 & 5,540 \\
\hline Diesel fuel (L) & $8.46 \mathrm{E}+05$ & $6.84 \mathrm{E}+05$ \\
\hline Excavated material $\left(\mathrm{m}^{3}\right)$ & $1.44 \mathrm{E}+06$ & $1.16 \mathrm{E}+06$ \\
\hline
\end{tabular}

\section{TABLE 6.26 Resources Required during Operations of Mined Cavity Facility}

\begin{tabular}{|c|c|c|c|c|}
\hline \multirow[b]{2}{*}{ Item } & \multicolumn{2}{|c|}{ 30-gal Drums } & \multicolumn{2}{|c|}{ 55-gal Drums } \\
\hline & Annual & Total $^{\mathrm{a}}$ & Annual & Total $^{\mathrm{a}}$ \\
\hline \multicolumn{5}{|c|}{500,000 Metric Tons of $U F_{4}$} \\
\hline Water $\left(10^{6} \mathrm{~L}\right)$ & 3.09 & 61.8 & 2.33 & 46.5 \\
\hline Electricity (MWh) & 8,310 & $1.66 \mathrm{E}+05$ & 6,140 & $1.23 \mathrm{E}+05$ \\
\hline Diesel fuel (L) & 9,300 & $1.86 \mathrm{E}+05$ & 6,230 & $1.25 \mathrm{E}+05$ \\
\hline \multicolumn{5}{|c|}{630,000 Metric Tons of $U F_{4}$} \\
\hline Water $\left(10^{6} \mathrm{~L}\right)$ & 3.10 & 77.5 & 2.33 & 58.3 \\
\hline Electricity (MWh) & 8,340 & $2.09 \mathrm{E}+05$ & 6,160 & $1,54 \mathrm{E}+05$ \\
\hline Diesel fuel (L) & 9,350 & $2.34 \mathrm{E}+05$ & 6,260 & $1.57 \mathrm{E}+05$ \\
\hline
\end{tabular}

a Totals are for 20 years of operations for 500,000 metric tons of $\mathrm{UF}_{4}$ and 25 years of operations for 630,000 metric tons of $\mathrm{UF}_{4}$. 
TABLE 6.27 Total Materials and Resources Required during Construction of Wasteform Facility

\begin{tabular}{|c|c|c|}
\hline Item & $\begin{array}{l}30 \text {-gal } \\
\text { Drums }\end{array}$ & $\begin{array}{l}55 \text {-gal } \\
\text { Drums }\end{array}$ \\
\hline \multicolumn{3}{|c|}{ 500,000 Metric Tons of $U F_{4}$} \\
\hline Water $\left(10^{6} \mathrm{~L}\right)$ & 3.3 & 2.7 \\
\hline Concrete Redi-Mix $\left(\mathrm{m}^{3}\right)$ & 5,591 & 4,286 \\
\hline Steel (metric tons) & 349 & 271 \\
\hline Excavated material $\left(\mathrm{m}^{3}\right)$ & 9,550 & 7,550 \\
\hline Electricity (MWh) & 480 & 410 \\
\hline Masonry brick (m $\left.{ }^{2}\right)$ & 573 & 573 \\
\hline Diesel fuel (L) & 90,000 & 70,000 \\
\hline \multicolumn{3}{|c|}{ 630,000 Metric Tons of $U F_{4}$} \\
\hline Water $\left(10^{6} \mathrm{~L}\right)$ & 3.4 & 2.7 \\
\hline Concrete Redi-Mix $\left(\mathrm{m}^{3}\right)$ & 5,724 & 4,286 \\
\hline Steel (metric tons) & 357 & 271 \\
\hline Excavated material $\left(\mathrm{m}^{3}\right)$ & 9,750 & 7,550 \\
\hline Electricity (MWh) & 487 & 410 \\
\hline Masonry brick (m $\left.{ }^{2}\right)$ & 573 & 573 \\
\hline Diesel fuel (L) & 92,000 & 70,000 \\
\hline
\end{tabular}

TABLE 6.28 Total Concrete Required for Wasteform Facility

\begin{tabular}{|c|c|c|c|c|}
\hline \multirow[b]{2}{*}{ Structure } & \multicolumn{4}{|c|}{ Concrete Required $\left(\mathrm{m}^{3}\right)$} \\
\hline & Floor & Walls & Rook & Total \\
\hline \multicolumn{5}{|c|}{500,000 Metric Tons of $U F_{4}$} \\
\hline \multicolumn{5}{|l|}{ Warehouse $^{\mathrm{a}}$} \\
\hline 30-gal drums & 2,482 & 759 & 2,068 & 5,308 \\
\hline 55-gal drums & 1,871 & 572 & 1,559 & 4,003 \\
\hline Administration bldg. & 88 & 94 & 101 & 283 \\
\hline \multicolumn{5}{|c|}{ 630,000 Metric Tons of $U F_{4}$} \\
\hline \multicolumn{5}{|l|}{ Warehouse $^{\mathrm{a}}$} \\
\hline 30-gal drums & 2,544 & 778 & 2,120 & 5,441 \\
\hline 55-gal drums & 1,871 & 572 & 1,559 & 4,003 \\
\hline Administration bldg. & 88 & 94 & 101 & 283 \\
\hline
\end{tabular}

${ }^{\mathrm{a}}$ Warehouse $=$ product receiving and shipping warehouse. 
TABLE 6.29 Resources Required during Operations of Wasteform Facility

\begin{tabular}{|c|c|c|c|c|}
\hline \multirow[b]{2}{*}{ Item } & \multicolumn{2}{|c|}{ 30-gal Drums } & \multicolumn{2}{|c|}{ 55-gal Drums } \\
\hline & Annual & Total $^{\mathrm{a}}$ & Annual & Total $^{\mathrm{a}}$ \\
\hline \multicolumn{5}{|l|}{500,000 Metric Tons of $U F_{4}$} \\
\hline Water $\left(10^{6} \mathrm{~L}\right)$ & 0.62 & 12 & 0.52 & 10 \\
\hline Natural gas, therms $(1 \mathrm{E}+05 \mathrm{Btu})$ & 141 & 2,830 & 112 & 2,240 \\
\hline Electricity (MWh) & 671 & 13,400 & 579 & 11,600 \\
\hline Diesel fuel (L) & 556 & 11,100 & 502 & 10,000 \\
\hline \multicolumn{5}{|l|}{630,000 Metric Tons of $U F_{4}$} \\
\hline Water $\left(10^{6} \mathrm{~L}\right)$ & 0.63 & 16 & 0.52 & 13 \\
\hline Natural gas, therms $(1 \mathrm{E}+05 \mathrm{Btu})$ & 144 & 3,610 & 112 & 2,800 \\
\hline Electricity (MWh) & 680 & 17,000 & 579 & 14,500 \\
\hline Diesel fuel (L) & 561 & 14,000 & 502 & 12,600 \\
\hline
\end{tabular}

\subsection{LAND USE}

Land area requirements for each disposal option were presented in Tables 5.2 through 5.4. These data did not include acreage required for constructing any of the disposal options because the development of land would occur incrementally, and the space needed for excavation material storage areas, equipment staging areas, and construction material laydown areas would be available on adjacent, undeveloped parcels. Consequently, areal needs for construction would not be greater than those for operations.

If the facility site selected was at or near a location that is already used for a similar purpose, land-use impacts could be reduced, because immediate access to infrastructure and utility support would require only minor disturbances to existing land use.

All disposal options would include a central wasteform facility where drums would be received from the conversion facility and prepared for disposal. Impacts on land use from the wasteform facility would be very small and limited to clearing of required land and possibly minor and temporary disruptions to contiguous land parcels. No off-site impacts would be expected.

Land-use impacts resulting from the shallow earthen structure disposal option would be negligible to moderate and limited to clearing of required land and possibly a slight increase in the amount of off-site vehicular traffic associated with construction activities. The large volume of 
excavated material that would remain on site could, over time, result in topographical modifications of the site. Impacts from off-site disposal would be determined during the site-specific tier of National Environmental Policy Act (NEPA) documentation. Other than minor, temporary impacts associated with construction traffic, no other off-site impacts would be expected.

Because the vault facility would be constructed incrementally (10 vault blocks per year), the amount of land disturbed during a given year would be limited. Impacts from off-site disposal would be determined during the site-specific tier of NEPA documentation.

Of all the disposal options, a mine would have the greatest potential for land-use impacts because it would require the largest amount of land (see Tables 5.3 and 5.4). The construction associated with this option could disturb adjacent parcels of land. The large volume of excavated material would be disposed of on site, probably resulting in topographical modifications of the site. The peak construction labor force could cause off-site land-use impacts, particularly if a remote site was chosen. Impacts could involve existing commercial land and traffic on local access roads and intersections.

\subsection{OTHER IMPACTS CONSIDERED BUT NOT ANALYZED IN DETAIL}

Other impacts that could occur if the disposal options considered in this report were implemented include impacts on cultural resources, environmental justice, the visual environment (e.g., aesthetics), recreational resources, and noise levels. Impacts could also result from the decontamination and decommissioning of the disposal facilities. These impacts were considered but could not be analyzed in detail without knowledge of the specific sites. These impacts could be more appropriately addressed in later NEPA documentation when specific sites are being considered. 


\section{IMPACTS OF OPTIONS - POST-CLOSURE PHASE}

This section provides a summary of the potential environmental impacts associated with the post-closure phase of the disposal options. The post-closure phase covers a future time, well beyond the time any engineered disposal facility would be expected to function as designed. Postclosure impacts were evaluated because no matter how well-designed a disposal facility would be, it would still probably release uranium compounds to the environment. This condition is referred to as "failure."

Disposal facility failure would generally occur hundreds to thousands of years in the future (assuming there was no sustained effort to maintain the facility). This failure would be caused by natural degradation of the disposal structures over time, primarily from physical processes such as the intrusion of water. Following failure, the release of uranium from the facility would occur very slowly as water moved through the disposed material. This water would carry dissolved uranium through the soil under the facility, eventually contaminating the groundwater. This process could continue for thousands to millions of years because of the large amount of uranium in the disposal facility and low solubility of that uranium.

In general, shallow earthen structures would be expected to contain waste material for at least several hundred years before failure. Vaults and a mine would be expected to last even longer before failure, from many hundreds of years to thousands of years. However, the exact time that a disposal facility would be expected to fail is extremely difficult to predict and would depend on the detailed facility design and site-specific conditions. Because of this uncertainty, failure was assumed to occur at the end of a period of institutional control, 100 years after closure. The post-closure impacts were evaluated at 1,000 years after failure for all three disposal facility options.

Potential post-closure impacts were evaluated on three areas: (1) groundwater, (2) human health and safety, and (3) ecological resources. Impacts on other areas would be expected to be negligible. The following general assumptions apply to the assessment of post-closure impacts:

C All disposal facilities would fail at some time in the future. Failure is defined as the release of uranium material from the disposal facility to the surrounding soil. For consistency, failure was assumed to occur at the end of institutional control, 100 years after closure.

C The post-closure phase primarily considers potential impacts from the contamination of groundwater and surface water. Potential impacts from the contamination of air and soil due to erosion of the disposal facility surface are also discussed. 
C The impacts evaluated were those that would occur 1,000 years after the facility failed and started to release uranium.

C For analysis of groundwater impacts, assumptions were varied to assess a broad range of possibilities with respect to movement of the uranium through the soil to the groundwater aquifer.

The estimated impacts associated with the post-closure phase are subject to a great deal of uncertainty because the assessment considers an extremely long period of time and depends on predicting the behavior of the waste material as it interacts with soil and water in a complex and changing environment. Consequently, the estimated impacts are very dependent on the assessment assumptions. Key assumptions include such factors as soil characteristics, water infiltration rates, depth to the underlying groundwater table, chemistry of different uranium compounds, and the locations of future human receptors. These factors can vary widely depending on site-specific conditions. Because of these uncertainties, the assumptions were generally selected in a manner intended to produce conservative estimates of impact, that is, the assumptions tend to overestimate the expected impact. Changes in key disposal assumptions could yield significantly different estimates of impact.

\subsection{HUMAN HEALTH - NORMAL OPERATIONS}

\subsubsection{Radiological Impacts}

Radiation doses and cancer risks for the post-closure phase were assessed for a hypothetical individual who would live at or near the disposal site after the institutional control period of the site ended. This individual was assumed to drill a well at the edge of the disposal site and use the well water for drinking, household purposes, irrigating plant foods and fodder, and watering livestock. Because of leaching of uranium from the disposal area to the groundwater table, the hypothetical resident could be exposed to radiation through use of contaminated well water. Detailed discussions of the methodologies used in radiological impact analyses are provided in Cheng et al. (1997). Additional information on the methodology and assumptions used in the groundwater analyses is provided in Section 7.2.

The estimated groundwater concentrations involve large degrees of uncertainty because of the preliminary nature of facility design and the various soil properties that depend on the location of the facility. The radiological impacts estimated by using the groundwater concentrations are subject to a large degree of uncertainty as well. The groundwater contamination would persist for millions of years once it occurred because of the large inventory of $\mathrm{UF}_{4}$ in the disposal area. Because of the long decay half-lives of uranium isotopes and the continuous generation of decay products, 
the maximum radiation dose, which could be greater than $1 \mathrm{rem} / \mathrm{yr}$ from using contaminated groundwater, would not be observed until sometime after 10,000 years, a time frame well beyond that considered in this analysis. Table 7.1 lists the calculated radiation doses and cancer risks for the maximally exposed individual (MEI) 1,000 years after the failure of engineering barriers and waste containers. Because of the assumption that the disposal facility would be at a dry location, potential radiation exposure would be minimal at that time, less than $3 \times 10^{-6} \mathrm{mrem} / \mathrm{yr}$.

In addition to the possible exposures resulting from use of contaminated groundwater, radiological impacts could be caused by external radiation and inhalation of contaminated dust particles if all the cover materials above the disposal site were removed and if containers of $U_{4}$ disintegrated. This scenario could be caused by natural forces of erosion over long periods of time or by human intervention (i.e., digging) to bring the waste to the surface. The associated external radiation dose could be as high as $10 \mathrm{rem} / \mathrm{yr}$ for an individual living on the disposal site. However, the exposure would not occur until several thousand years after closure of the shallow earthen structure or vault disposal facility, and exposure would be quite unlikely if mines were used for disposal because a mine would be located several hundred feet below the ground surface. Detailed analyses for this exposure scenario were not conducted because the time frame would be beyond that considered in this analysis. If any exposure would occur, the radiation dose could be eliminated by adding new cover materials to the top of the waste area.

\subsubsection{Disposal of 500,000 Metric Tons of $\mathrm{UF}_{4}$}

Radiological impacts are listed in Table 7.1 for a scenario in which an individual uses contaminated groundwater. In a dry setting, because of the low water infiltration rate and the long distance from the bottom of the disposal area to the groundwater table, the amount of radionuclides that would reach the groundwater table within 1,000 years would be very small.

\subsubsection{Disposal of 630,000 Metric Tons of $\mathbf{U F}_{4}$}

Potential radiation exposure from using contaminated groundwater would be slightly greater for disposal of 630,000 metric tons of $\mathrm{UF}_{4}$ than for disposal of 500,000 metric tons of $\mathrm{UF}_{4}$, because

of the larger disposal area used. However, in a dry location, as was assumed for the analysis, the amount of radionuclides that would reach the groundwater table 1,000 years after failure of the disposal facility would still be minimal. The estimated maximum radiation dose would be less than $3 \times 10^{-6} \mathrm{mrem} / \mathrm{yr}$. 
TABLE 7.1 Estimated Human Health Impacts to the MEI under UF Disposal Options during the Post-Closure Phase

\begin{tabular}{|c|c|c|c|}
\hline \multirow[b]{2}{*}{ Option/Inventory $^{\mathrm{a}}$} & \multicolumn{2}{|c|}{$\begin{array}{l}\text { Radiological Impacts } \\
\text { at } 1,000 \text { Years }\end{array}$} & \multirow{2}{*}{$\begin{array}{c}\text { Chemical Impacts } \\
\text { at 1,000 Years } \\
\text { MEI Hazard } \\
\text { Index }\end{array}$} \\
\hline & $\begin{array}{l}\text { MEI Dose } \\
(\mathrm{mrem} / \mathrm{yr})\end{array}$ & $\begin{array}{l}\text { MEI risk } \\
(\mathrm{LCF} / \mathrm{yr})\end{array}$ & \\
\hline \multicolumn{4}{|c|}{ Disposal of 500,000 Metric Tons of $U_{4}$} \\
\hline $\begin{array}{l}\text { Shallow earthen structure } \\
\text { 30-gal drums } \\
\text { 55-gal drums }\end{array}$ & $\begin{array}{l}<2.2 \times 10^{-8} \\
<2.0 \times 10^{-8}\end{array}$ & $\begin{array}{l}<1 \times 10^{-14} \\
<1 \times 10^{-14}\end{array}$ & $\begin{array}{l}3 \times 10^{-9} \\
2 \times 10^{-9}\end{array}$ \\
\hline $\begin{array}{l}\text { Vault } \\
\text { 30-gal drums } \\
\text { 55-gal drums }\end{array}$ & $\begin{array}{l}<2.9 \times 10^{-8} \\
<3.2 \times 10^{-8}\end{array}$ & $\begin{array}{l}<1 \times 10^{-14} \\
<2 \times 10^{-14}\end{array}$ & $\begin{array}{l}4 \times 10^{-9} \\
2 \times 10^{-9}\end{array}$ \\
\hline $\begin{array}{l}\text { Mine } \\
\text { 30-gal drums } \\
\text { 55-gal drums }\end{array}$ & $\begin{array}{l}<2.3 \times 10^{-6} \\
<2.0 \times 10^{-6}\end{array}$ & $\begin{array}{l}<1 \times 10^{-12} \\
<1 \times 10^{-12}\end{array}$ & $\begin{array}{l}3 \times 10^{-7} \\
2 \times 10^{-7}\end{array}$ \\
\hline Disposal of 630,000 Met & of $U F_{4}$ & & \\
\hline $\begin{array}{l}\text { Shallow earthen structure } \\
\text { 30-gal drums } \\
\text { 55-gal drums }\end{array}$ & $\begin{array}{l}<2.4 \times 10^{-8} \\
<2.2 \times 10^{-8}\end{array}$ & $\begin{array}{l}<1 \times 10^{-14} \\
<1 \times 10^{-14}\end{array}$ & $\begin{array}{l}3 \times 10^{-9} \\
3 \times 10^{-9}\end{array}$ \\
\hline $\begin{array}{l}\text { Vault } \\
\text { 30-gal drums } \\
\text { 55-gal drums }\end{array}$ & $\begin{array}{l}<2.9 \times 10^{-8} \\
<3.2 \times 10^{-8}\end{array}$ & $\begin{array}{l}<1 \times 10^{-14} \\
<2 \times 10^{-14}\end{array}$ & $\begin{array}{l}4 \times 10^{-9} \\
4 \times 10^{-9}\end{array}$ \\
\hline $\begin{array}{l}\text { Mine } \\
\text { 30-gal drums } \\
\text { 55-gal drums }\end{array}$ & $\begin{array}{l}<2.5 \times 10^{-6} \\
<2.1 \times 10^{-6}\end{array}$ & $\begin{array}{l}<1 \times 10^{-12} \\
<1 \times 10^{-12}\end{array}$ & $\begin{array}{l}3 \times 10^{-7} \\
4 \times 10^{-7}\end{array}$ \\
\hline
\end{tabular}

a Two inventories were considered for each option: 500,000 metric tons of $\mathrm{UF}_{4}$ and 630,000 metric tons of $U_{4}$. The first inventory results from converting 560,000 metric tons of $\mathrm{UF}_{6}$ that DOE facilities generated in the past. The second inventory results from converting 705,000 metric tons of $\mathrm{UF}_{6}$ that both DOE generated and USEC generated.

b Impacts are reported as the maximum values, which result from considering different solubilities of uranium compounds that may be formed and different transport speeds of radionuclides in the unsaturated and saturated zones. Retardation factors of 5 and 50 were used to represent relatively mobile and immobile transport situations, respectively. Solubilities considered a range from $2.4 \times 10^{-3}$ to $24 \mathrm{~g} / \mathrm{L}$.

$\mathrm{c}$ The maximally exposed individual (MEI) was assumed to live at the edge of the disposal site and use contaminated groundwater for drinking, irrigating plant food and fodder, and feeding livestock. The exposure pathways considered were ingestion of drinking water, plant foods, meat, and milk; and, for radiological exposures, inhalation of radon emanating from household water.

$\mathrm{d}$

The hazard index is an indicator for potential adverse health effects other than cancer; a hazard index of greater than 1 indicates a potential for adverse health effects and a need for further evaluation. 


\subsubsection{Chemical Impacts}

Chemical impacts during the post-closure phase were assessed for a hypothetical individual who lives at the border of the disposal site after the institutional control period is over. As they were for the radiological assessment, potential chemical impacts on human health were evaluated for a scenario involving a hypothetical individual who drills a well at the edge of the disposal site and uses the well water for drinking, irrigating plant foods and fodder, and watering livestock. Leaching of uranium from the disposal area to the groundwater table could potentially result in the hypothetical resident being exposed to uranium from ingestion of drinking water, plant foods, meat, and milk. Risks are estimated on the basis of calculated hazard indices. Information on the exposure assumptions, health effects assumptions, reference doses used for uranium compounds, and calculational methods used in the chemical impact analysis are provided in Appendix C of the PEIS (DOE 1999) and Cheng et al. (1997).

Potential health impacts on the general public MEI from exposures to hazardous chemicals due to use of groundwater are listed in Table 7.1. The hazard indices for chemical impacts are essentially zero because of the assumption that the disposal facility would be located in a dry environmental setting.

\subsection{GROUNDWATER}

For the three disposal options during the post-closure phase, there would be no impacts on effective recharge, depth to groundwater, or the direction of groundwater flow. Water quality would be the only groundwater feature that might be affected. With time, the disposal facilities would fail and allow water to infiltrate the storage area. This water could corrode the drums and permit leaching of their contents. Because $\mathrm{UF}_{4}$ is soluble and undergoes hydrolysis, a wide variety of uranium compounds could form. One of the uranium compounds is schoepite $\left(\mathrm{UO}_{3}\left(\mathrm{dH}_{2} \mathrm{O}\right)\right.$. Other more complex compounds would also be possible, depending on site-specific conditions.

For each mole of schoepite formed, four moles of HF would be released. HF is a weak acid (i.e., it does not readily dissociate into hydrogen and fluoride ions); however, it is very corrosive and readily forms a gas (volatilizes). Specific analyses of the impact of HF on groundwater were not performed for the following reasons: HF has low vapor pressure and boils at room temperatures, thereby reducing the aqueous phase concentration; HF is very corrosive and reacts readily with its surroundings, particularly the metal drums containing the disposed $\mathrm{UF}_{4}$; as an ion, fluoride has a moderately high coefficient for sorption while in transport (Tomasko 2001); and the U.S. Environmental Protection Agency (EPA) maximum contaminant level (MCL) for fluoride $(4 \mathrm{mg} / \mathrm{L})$ is much higher than the proposed MCL for uranium $(20: \mathrm{g} / \mathrm{L})$ (EPA 1996). 
With additional time (several hundred to thousands of years), the facility would fail completely, and dissolved uranium complexes would infiltrate the soil beneath the structure and interact with soil water present in the unsaturated zone. Transport of the dissolved uranium would be influenced by advection, dispersion, adsorption, and decay (Tomasko 1997).

At the water table, the dissolved uranium compounds would mix with initially clean water in the uppermost groundwater aquifer and be diluted. After mixing and dilution, the contaminants would be transported in a direction consistent with natural flow. Advection, dispersion, adsorption, and decay would again influence the transport process (Tomasko 1997).

Uranium concentrations and activities at the water table for a dry environmental setting are summarized in Tables 7.2 and 7.3 for 1,000 years after failure for a shallow earthen structure, vault, and mine. Values are reported for initial total inventories of 500,000 and 630,000 metric tons of $\mathrm{UF}_{4}$, disposal in 30-gal and 55-gal drums, fairly mobile (retardation equal to 5) and fairly immobile transport (retardation equal to 50), and low-solubility and high-solubility uranium compounds. Details on these calculations can be found in Tomasko (2001).

The highest uranium groundwater concentrations, $8.6 \times 10^{-6} \mathrm{pCi} / \mathrm{L}\left(5.5 \times 10^{-5}: \mathrm{g} / \mathrm{L}\right)$, would result from a failed mine in which 500,000 metric tons of $\mathrm{UF}_{4}$ was disposed of in 30 -gal drums. The lowest concentrations, $1.2 \times 10^{-9} \mathrm{pCi} / \mathrm{L}\left(5.2 \times 10^{-9}: \mathrm{g} / \mathrm{L}\right)$, would result from disposing of 500,000 metric tons of $\mathrm{UF}_{4}$ in a shallow earthen structure in 55-gal drums. All of the predicted concentrations would be much less than the proposed MCL of $20: \mathrm{g} / \mathrm{L}$ (EPA 1996) used for comparison. Impacts on groundwater quality could be further reduced by decreasing the size of the facility in a direction parallel to the direction of groundwater flow, thereby increasing dilution.

Varying the distance to the receptor from 0 to $1,000 \mathrm{ft}(300 \mathrm{~m})$ would have no effect on concentrations because of the short travel distance and the travel velocity of the groundwater.

\subsection{ECOLOGY}

Predicted concentrations of contaminants in groundwater were compared to benchmark values of toxic and radiological effects to assess impacts to biota. A discussion of the assessment methodology is presented in Appendix C of the PEIS (DOE 1999). 
TABLE 7.2 Concentrations 1,000 Years after Dilution at the Water Table for Disposal of 500,000 Metric Tons of $\mathbf{U F}_{4}$

\begin{tabular}{|c|c|c|c|c|c|c|c|}
\hline \multirow[b]{2}{*}{$\begin{array}{l}\text { Solubility } \\
(\mathrm{g} / \mathrm{L})\end{array}$} & \multirow[b]{2}{*}{ Facility } & \multicolumn{3}{|c|}{ 30-gal Drums } & \multicolumn{3}{|c|}{ 55-gal Drums } \\
\hline & & $\mathrm{C} / \mathrm{C}_{\mathrm{o}}$ & $\begin{array}{l}\text { Concen- } \\
\text { tration } \\
(\mathrm{g} / \mathrm{L})\end{array}$ & $\begin{array}{c}\text { Activity } \\
\text { Concentration } \\
(\mathrm{pCi} / \mathrm{L})\end{array}$ & $\mathrm{C} / \mathrm{C}_{\mathrm{o}}$ & $\begin{array}{l}\text { Concen- } \\
\text { tration } \\
(\mathrm{g} / \mathrm{L})\end{array}$ & $\begin{array}{c}\text { Activity } \\
\text { Concentration } \\
(\mathrm{pCi} / \mathrm{L})\end{array}$ \\
\hline \multirow[t]{3}{*}{$2.4 \times 10^{-3}$} & $\begin{array}{l}\text { Shallow earthen } \\
\text { structure }\end{array}$ & $\begin{array}{l}2.4 \times 10^{-12} \\
6.9 \times 10^{-24}\end{array}$ & $\begin{array}{l}5.8 \times 10^{-15} \\
1.7 \times 10^{-26}\end{array}$ & $\begin{array}{c}1.4 \times 10^{-9} \\
4.1 \times 10^{-21}\end{array}$ & $\begin{array}{l}2.2 \times 10^{-12} \\
6.3 \times 10^{-24}\end{array}$ & $\begin{array}{l}5.2 \times 10^{-15} \\
1.6 \times 10^{-26}\end{array}$ & $\begin{array}{c}1.2 \times 10^{-9} \\
3.7 \times 10^{-21}\end{array}$ \\
\hline & Vault & $\begin{array}{l}2.6 \times 10^{-12} \\
7.6 \times 10^{-24}\end{array}$ & $\begin{array}{l}6.3 \times 10^{-15} \\
1.9 \times 10^{-26}\end{array}$ & $\begin{array}{c}1.5 \times 10^{-9} \\
4.5 \times 10^{-21}\end{array}$ & $\begin{array}{l}2.9 \times 10^{-12} \\
8.5 \times 10^{-24}\end{array}$ & $\begin{array}{l}7.0 \times 10^{-15} \\
2.1 \times 10^{-26}\end{array}$ & $\begin{array}{c}1.7 \times 10^{-9} \\
5.0 \times 10^{-21}\end{array}$ \\
\hline & Mine & $\begin{array}{l}1.5 \times 10^{-11} \\
6.6 \times 10^{-12}\end{array}$ & $\begin{array}{l}3.7 \times 10^{-14} \\
1.6 \times 10^{-14}\end{array}$ & $\begin{array}{l}9.0 \times 10^{-9} \\
3.8 \times 10^{-9}\end{array}$ & $\begin{array}{l}1.3 \times 10^{-11} \\
5.8 \times 10^{-12}\end{array}$ & $\begin{array}{l}3.2 \times 10^{-14} \\
1.4 \times 10^{-14}\end{array}$ & $\begin{array}{l}7.8 \times 10^{-9} \\
3.3 \times 10^{-9}\end{array}$ \\
\hline \multirow[t]{3}{*}{24} & $\begin{array}{l}\text { Shallow earthen } \\
\text { structure }\end{array}$ & $\begin{array}{l}2.2 \times 10^{-14} \\
3.8 \times 10^{-24}\end{array}$ & $\begin{array}{l}5.1 \times 10^{-13} \\
9.2 \times 10^{-23}\end{array}$ & $\begin{array}{l}8.1 \times 10^{-8} \\
1.5 \times 10^{-17}\end{array}$ & $\begin{array}{l}2.0 \times 10^{-14} \\
3.5 \times 10^{-24}\end{array}$ & $\begin{array}{l}4.7 \times 10^{-13} \\
8.5 \times 10^{-23}\end{array}$ & $\begin{array}{c}7.5 \times 10^{-8} \\
1.4 \times 10^{-17}\end{array}$ \\
\hline & Vault & $\begin{array}{l}2.8 \times 10^{-14} \\
3.8 \times 10^{-24}\end{array}$ & $\begin{array}{l}6.6 \times 10^{-13} \\
9.0 \times 10^{-23}\end{array}$ & $\begin{array}{l}1.1 \times 10^{-7} \\
1.5 \times 10^{-17}\end{array}$ & $\begin{array}{l}3.1 \times 10^{-14} \\
4.2 \times 10^{-24}\end{array}$ & $\begin{array}{l}7.4 \times 10^{-13} \\
1.0 \times 10^{-22}\end{array}$ & $\begin{array}{l}1.2 \times 10^{-7} \\
1.6 \times 10^{-17}\end{array}$ \\
\hline & Mine & $\begin{array}{l}2.2 \times 10^{-12} \\
2.2 \times 10^{-14}\end{array}$ & $\begin{array}{l}5.5 \times 10^{-11} \\
5.1 \times 10^{-13}\end{array}$ & $\begin{array}{l}8.6 \times 10^{-6} \\
8.2 \times 10^{-8}\end{array}$ & $\begin{array}{l}1.9 \times 10^{-12} \\
1.9 \times 10^{-14}\end{array}$ & $\begin{array}{l}4.6 \times 10^{-11} \\
4.5 \times 10^{-13}\end{array}$ & $\begin{array}{l}7.4 \times 10^{-6} \\
7.2 \times 10^{-8}\end{array}$ \\
\hline
\end{tabular}

TABLE 7.3 Concentrations 1,000 Years after Dilution at the Water Table for Disposal of 630,000 Metric Tons of $\mathbf{U F}_{4}$

\begin{tabular}{|c|c|c|c|c|c|c|c|}
\hline \multirow[b]{2}{*}{$\begin{array}{c}\text { Solubility } \\
(\mathrm{g} / \mathrm{L})\end{array}$} & \multirow[b]{2}{*}{ Facility } & \multicolumn{3}{|c|}{ 30-gal Drums } & \multicolumn{3}{|c|}{ 55-gal Drums } \\
\hline & & $\mathrm{C} / \mathrm{C}_{\mathrm{o}}$ & $\begin{array}{c}\text { Concen- } \\
\text { tration } \\
(\mathrm{g} / \mathrm{L})\end{array}$ & $\begin{array}{c}\text { Activity } \\
\text { Concentration } \\
(\mathrm{pCi} / \mathrm{L})\end{array}$ & $\mathrm{C} / \mathrm{C}_{\mathrm{o}}$ & $\begin{array}{l}\text { Concen- } \\
\text { tration } \\
(\mathrm{g} / \mathrm{L})\end{array}$ & $\begin{array}{c}\text { Activity } \\
\text { Concentration } \\
(\mathrm{pCi} / \mathrm{L})\end{array}$ \\
\hline \multirow[t]{3}{*}{$2.4 \times 10^{-3}$} & $\begin{array}{l}\text { Shallow earthen } \\
\text { structure }\end{array}$ & $\begin{array}{l}2.6 \times 10^{-12} \\
7.7 \times 10^{-24}\end{array}$ & $\begin{array}{l}6.3 \times 10^{-15} \\
1.9 \times 10^{-26}\end{array}$ & $\begin{array}{l}1.5 \times 10^{-9} \\
4.5 \times 10^{-21}\end{array}$ & $\begin{array}{l}2.4 \times 10^{-12} \\
7.1 \times 10^{-24}\end{array}$ & $\begin{array}{l}5.8 \times 10^{-15} \\
1.7 \times 10^{-26}\end{array}$ & $\begin{array}{c}1.4 \times 10^{-9} \\
4.2 \times 10^{-21}\end{array}$ \\
\hline & Vault & $\begin{array}{l}2.9 \times 10^{-12} \\
7.7 \times 10^{-24}\end{array}$ & $\begin{array}{l}7.0 \times 10^{-15} \\
5.0 \times 10^{-21}\end{array}$ & $\begin{array}{l}1.7 \times 10^{-9} \\
1.2 \times 10^{-15}\end{array}$ & $\begin{array}{l}3.2 \times 10^{-12} \\
9.3 \times 10^{-24}\end{array}$ & $\begin{array}{l}7.7 \times 10^{-15} \\
2.3 \times 10^{-26}\end{array}$ & $\begin{array}{c}1.8 \times 10^{-9} \\
5.5 \times 10^{-21}\end{array}$ \\
\hline & Mine & $\begin{array}{l}1.7 \times 10^{-11} \\
7.4 \times 10^{-12}\end{array}$ & $\begin{array}{l}4.1 \times 10^{-14} \\
1.8 \times 10^{-14}\end{array}$ & $\begin{array}{l}1.0 \times 10^{-8} \\
4.2 \times 10^{-9}\end{array}$ & $\begin{array}{l}1.5 \times 10^{-11} \\
6.5 \times 10^{-12}\end{array}$ & $\begin{array}{l}3.6 \times 10^{-14} \\
1.5 \times 10^{-14}\end{array}$ & $\begin{array}{l}8.8 \times 10^{-9} \\
3.7 \times 10^{-9}\end{array}$ \\
\hline \multirow[t]{3}{*}{24} & $\begin{array}{l}\text { Shallow earthen } \\
\text { structure }\end{array}$ & $\begin{array}{l}2.3 \times 10^{-14} \\
4.8 \times 10^{-24}\end{array}$ & $\begin{array}{l}5.5 \times 10^{-13} \\
1.1 \times 10^{-22}\end{array}$ & $\begin{array}{c}8.9 \times 10^{-8} \\
1.8 \times 10^{-17}\end{array}$ & $\begin{array}{l}2.1 \times 10^{-14} \\
4.4 \times 10^{-24}\end{array}$ & $\begin{array}{l}5.0 \times 10^{-13} \\
1.1 \times 10^{-22}\end{array}$ & $\begin{array}{c}8.0 \times 10^{-8} \\
1.8 \times 10^{-17}\end{array}$ \\
\hline & Vault & $\begin{array}{l}2.8 \times 10^{-14} \\
4.8 \times 10^{-24}\end{array}$ & $\begin{array}{l}6.6 \times 10^{-13} \\
1.2 \times 10^{-22}\end{array}$ & $\begin{array}{l}1.1 \times 10^{-7} \\
1.8 \times 10^{-17}\end{array}$ & $\begin{array}{l}3.1 \times 10^{-14} \\
5.2 \times 10^{-24}\end{array}$ & $\begin{array}{l}7.4 \times 10^{-13} \\
1.3 \times 10^{-22}\end{array}$ & $\begin{array}{l}1.2 \times 10^{-7} \\
2.1 \times 10^{-17}\end{array}$ \\
\hline & Mine & $\begin{array}{l}2.4 \times 10^{-12} \\
3.0 \times 10^{-14}\end{array}$ & $\begin{array}{l}5.7 \times 10^{-11} \\
7.0 \times 10^{-13}\end{array}$ & $\begin{array}{l}9.2 \times 10^{-6} \\
1.1 \times 10^{-7}\end{array}$ & $\begin{array}{l}2.1 \times 10^{-12} \\
2.6 \times 10^{-14}\end{array}$ & $\begin{array}{l}5.0 \times 10^{-11} \\
6.2 \times 10^{-13}\end{array}$ & $\begin{array}{l}8.0 \times 10^{-6} \\
9.9 \times 10^{-8}\end{array}$ \\
\hline
\end{tabular}




\subsubsection{Disposal of 500,000 Metric Tons of $\mathrm{UF}_{4}$}

The disposal facilities considered would be expected to adequately prevent the release of their contents for considerable periods of time. Impacts on ecological resources due to the presence of the facility would not be expected to occur before facility failure. Failure of facility integrity would eventually result in contamination of groundwater. Groundwater could discharge to the surface (such as in wetland areas), thus exposing biota to contaminants. Groundwater concentrations of uranium compounds (e.g., $\mathrm{UO}_{3}\left(2 \mathrm{H}_{2} \mathrm{O}\right)$ were calculated for 1,000 years after facility failure (Section 7.2). Concentrations would be very low throughout the time period analyzed for a disposal facility located in a dry environmental setting (typical of the western United States, with less than $10 \mathrm{in.} / \mathrm{yr}[25 \mathrm{~cm} / \mathrm{yr}]$ precipitation). Ecological impacts are summarized in Table 7.4.

Failure of a shallow earthen structure disposal facility would result in groundwater concentrations of uranium compounds near the facility ranging from $1.6 \times 10^{-26}$ to $5.1 \times 10^{-13} \mathrm{~g} / \mathrm{L}$. Soluble uranium compounds can produce toxic effects in aquatic biota at concentrations as low as $1.5 \times 10^{-4} \mathrm{~g} / \mathrm{L}$. Toxic effects on an organism continuously exposed to the undiluted groundwater would be expected to be negligible. Uranium activity would range from $3.7 \times 10^{-21}$ to $8.1 \times 10^{-8} \mathrm{pCi} / \mathrm{L}$. Resulting dose rates to maximally exposed organisms would be much less than $0.015 \mathrm{rad} / \mathrm{d}$, less than $2 \%$ of the dose limit of $1 \mathrm{rad} / \mathrm{d}$ for aquatic organisms specified in DOE Order 5400.5 .

Failure of a facility for disposal in vaults would result in groundwater concentrations of uranium compounds ranging from $1.9 \times 10^{-26}$ to $7.4 \times 10^{-13} \mathrm{~g} / \mathrm{L}$. Toxic effects on an organism continuously exposed to this undiluted groundwater would be expected to be negligible. Uranium activity would range from $4.5 \times 10^{-21}$ to $1.2 \times 10^{-7} \mathrm{pCi} / \mathrm{L}$. Resulting dose rates to maximally exposed organisms would be much less than $0.015 \mathrm{rad} / \mathrm{d}$, less than $2 \%$ of the dose limit of $1 \mathrm{rad} / \mathrm{d}$.

Failure of a mine disposal facility would result in groundwater concentrations ranging from $1.4 \times 10^{-14}$ to $5.5 \times 10^{-11} \mathrm{~g} / \mathrm{L}$. Adverse impacts to aquatic biota would be expected to be negligible. Uranium activity would range from $3.3 \times 10^{-9}$ to $8.6 \times 10^{-6} \mathrm{pCi} / \mathrm{L}$. Resulting dose rates to maximally exposed organisms would be much less than $0.015 \mathrm{rad} / \mathrm{d}$, less than $2 \%$ of the dose limit of $1 \mathrm{rad} / \mathrm{d}$.

\subsubsection{Disposal of 630,000 Metric Tons of $\mathbf{U F}_{4}$}

Groundwater uranium concentrations resulting from the failure of a facility for disposal of 630,000 metric tons of $\mathrm{UF}_{4}$ would also be very low at 1,000 years for a facility in a dry environmental setting. 
TABLE 7.4 Potential Radiological and Chemical Impacts on Aquatic Biota from Failure of a Disposal Facility

\begin{tabular}{|c|c|c|}
\hline $\begin{array}{c}\text { Disposal Option/ } \\
\text { Contaminant in Groundwater }\end{array}$ & Maximum Exposure & Effect \\
\hline \multicolumn{3}{|c|}{ Disposal of 500,000 Metric Tons of $U_{F_{4}}$} \\
\hline \multicolumn{3}{|l|}{ Shallow earthen structure } \\
\hline Uranium activity & $3.7 \times 10^{-21}$ to $8.1 \times 10^{-8} \mathrm{pCi} / \mathrm{L}$ & Toxic effect: negligible \\
\hline Uranium concentration & $1.6 \times 10^{-26}$ to $5.1 \times 10^{-13} \mathrm{~g} / \mathrm{L}$ & Dose to MEI: negligible \\
\hline \multicolumn{3}{|l|}{ Vault } \\
\hline Uranium activity & $4.5 \times 10^{-21}$ to $1.2 \times 10^{-7} \mathrm{pCi} / \mathrm{L}$ & Toxic effect: negligible \\
\hline Uranium concentration & $1.9 \times 10^{-26}$ to $7.4 \times 10^{-13} \mathrm{~g} / \mathrm{L}$ & Dose to MEI: negligible \\
\hline \multicolumn{3}{|l|}{ Mine } \\
\hline Uranium activity & $3.3 \times 10^{-9}$ to $8.6 \times 10^{-6} \mathrm{pCi} / \mathrm{L}$ & Toxic effect: negligible \\
\hline Uranium concentration & $1.4 \times 10^{-14}$ to $5.5 \times 10^{-11} \mathrm{~g} / \mathrm{L}$ & Dose to MEI: negligible \\
\hline \multicolumn{3}{|c|}{ Disposal of 630,000 Metric Tons of $U_{4}$} \\
\hline \multicolumn{3}{|l|}{ Shallow earthen structure } \\
\hline Uranium activity & $4.2 \times 10^{-21}$ to $8.9 \times 10^{-8} \mathrm{pCi} / \mathrm{L}$ & Toxic effect: negligible \\
\hline Uranium concentration & $1.7 \times 10^{-26}$ to $5.5 \times 10^{-13} \mathrm{~g} / \mathrm{L}$ & Dose to MEI: negligible \\
\hline \multicolumn{3}{|l|}{ Vault } \\
\hline Uranium activity & $5.5 \times 10^{-21}$ to $1.2 \times 10^{-7} \mathrm{pCi} / \mathrm{L}$ & Toxic effect: negligible \\
\hline Uranium concentration & $2.3 \times 10^{-26}$ to $7.4 \times 10^{-13} \mathrm{~g} / \mathrm{L}$ & Dose to MEI: negligible \\
\hline \multicolumn{3}{|l|}{ Mine } \\
\hline Uranium activity & $3.7 \times 10^{-9}$ to $9.2 \times 10^{-6} \mathrm{pCi} / \mathrm{L}$ & Toxic effect: negligible \\
\hline Uranium concentration & $1.5 \times 10^{-14}$ to $5.7 \times 10^{-11} \mathrm{~g} / \mathrm{L}$ & Dose to MEI: negligible \\
\hline
\end{tabular}

Failure of a shallow earthen structure facility would result in groundwater concentrations of uranium compounds near the facility ranging from $1.7 \times 10^{-26}$ to $5.5 \times 10^{-13} \mathrm{~g} / \mathrm{L}$. Soluble uranium compounds can produce toxic effects in aquatic biota at concentrations as low as $1.5 \times 10^{-4} \mathrm{~g} / \mathrm{L}$. Toxic effects on an organism continuously exposed to the undiluted groundwater would be expected to be negligible. Uranium activity would range from $4.2 \times 10^{-21}$ to $8.9 \times 10^{-8} \mathrm{pCi} / \mathrm{L}$. Resulting dose rates to maximally exposed organisms would be much less than $0.015 \mathrm{rad} / \mathrm{d}$, less than $2 \%$ of the dose limit of $1 \mathrm{rad} / \mathrm{d}$.

Failure of a facility for disposal in vaults would result in groundwater concentrations of uranium compounds ranging from $2.3 \times 10^{-26}$ to $7.4 \times 10^{-13} \mathrm{~g} / \mathrm{L}$. Toxic effects on an organism continuously exposed to this undiluted groundwater would be expected to be negligible. Uranium 
activity would range from $5.5 \times 10^{-21}$ to $1.2 \times 10^{-7} \mathrm{pCi} / \mathrm{L}$. Resulting dose rates to maximally exposed organisms would be much less than $0.015 \mathrm{rad} / \mathrm{d}$, less than $2 \%$ of the dose limit of $1 \mathrm{rad} / \mathrm{d}$.

Failure of a mined cavity disposal facility would result in groundwater uranium concentrations ranging from $1.5 \times 10^{-14}$ to $5.7 \times 10^{-11} \mathrm{~g} / \mathrm{L}$. Adverse impacts to aquatic biota would be expected to be negligible. Uranium activity would range from $3.7 \times 10^{-9}$ to $9.2 \times 10^{-6} \mathrm{pCi} / \mathrm{L}$. Resulting dose rates to maximally exposed organisms would be considerably lower than the dose limit of $1 \mathrm{rad} / \mathrm{d}$. 


\section{TRANSPORTATION IMPACTS}

Disposal of $\mathrm{UF}_{4}$ would require it to be shipped from a conversion plant to the disposal facility. The $\mathrm{UF}_{4}$ would be packaged in 30-gal or 55-gal drums and shipped by either truck or train, in accordance with DOE and Department of Transportation regulatory requirements. The numbers of shipments required for both the original and new inventories are summarized in Table 8.1.

The assessment of potential transportation impacts considered both truck and rail shipment options and evaluated impacts from both normal (incident-free) transportation operations and accidents. Potential health impacts from both radiological and chemical exposures to $\mathrm{UF}_{4}$ were estimated. Because the locations of conversion and disposal facilities are not known, transportation impacts were estimated for representative routes with shipment distances of 250,1,000, and $5,000 \mathrm{~km}$ to provide a reasonable range. Additional transportation assumptions and discussion are provided in Appendix J of the PEIS (DOE 1999).

During normal transportation operations, $\mathrm{UF}_{4}$ would be contained in the transport packages. Potential health impacts would be possible from exposure to low-level external radiation in the vicinity of shipments. In addition, exposure to vehicle engine exhaust emissions could cause adverse effects.

Accidents could occur during the transportation of $\mathrm{UF}_{4}$. These accidents could potentially affect the health of workers (i.e., crew members) and members of the general public. Potential impacts were estimated for two types of accidents: (1) typical traffic accidents that could cause deaths from physical trauma, unrelated to the cargo being shipped, and (2) accidents that could involve the release of $\mathrm{UF}_{4}$ from a shipment, potentially resulting in radiological and chemical exposures.

The estimated risks during routine transportation operations are presented in Table 8.1. Accident risk estimates, which include the probability of accidents occurring, are summarized in Table 8.2. The potential consequences from severe accidents are summarized in Table 8.3 for populations and Table 8.4 for MEIs. Risks to an MEI during routine transportation conditions are summarized in Table 8.5.

In general, the total risks associated with depleted $\mathrm{UF}_{4}$ transport would be dominated by vehicle-related risks, which would be about 5 times larger than the radiological and chemical risks combined. Also, risks from transport by rail appear to be slightly less than the truck risks because rail transport is associated with higher shipment capacities and therefore fewer shipments. There are no significant differences between the 30-gal and 55-gal drum options because the total amount of material per shipment would remain approximately the same. 
TABLE 8.1 Total Risks from Routine Shipment of $\mathbf{U F}_{4}$

\begin{tabular}{|c|c|c|c|c|c|c|c|c|c|c|c|}
\hline \multirow[b]{2}{*}{$\begin{array}{c}\text { Drum } \\
\text { Size } \\
\text { (gal) }\end{array}$} & \multirow[b]{2}{*}{ Mode } & \multirow[b]{2}{*}{$\begin{array}{c}\text { Total } \\
\text { Shipments }\end{array}$} & \multicolumn{3}{|c|}{ Risks over $250 \mathrm{~km}$} & \multicolumn{3}{|c|}{ Risks over $1,000 \mathrm{~km}$} & \multicolumn{3}{|c|}{ Risks over $5,000 \mathrm{~km}$} \\
\hline & & & $\begin{array}{c}\text { Radiological } \\
\text { LCF }^{\mathrm{b}}\end{array}$ & $\begin{array}{c}\text { Chemical } \\
\text { Effects }\end{array}$ & $\begin{array}{c}\text { Vehicular } \\
\text { LCF }\end{array}$ & $\begin{array}{c}\text { Radiological } \\
\text { LCF }^{\mathrm{b}}\end{array}$ & $\begin{array}{c}\text { Chemical } \\
\text { Effects }\end{array}$ & $\begin{array}{c}\text { Vehicular } \\
\text { LCF }\end{array}$ & $\begin{array}{c}\text { Radiological } \\
\text { LCF }^{\mathrm{b}}\end{array}$ & $\begin{array}{c}\text { Chemical } \\
\text { Effects }\end{array}$ & $\begin{array}{c}\text { Vehicular } \\
\text { LCF }\end{array}$ \\
\hline \multicolumn{12}{|c|}{ 500,000 Metric Tons of $U F_{4}$} \\
\hline \multirow[t]{2}{*}{30} & Truck & 28,620 & 0.06 & 0 & 0.03 & 0.2 & 0 & 0.1 & 1 & 0 & 0.7 \\
\hline & Rail & 10,480 & 0.02 & 0 & 0.008 & 0.04 & 0 & 0.03 & 0.1 & 0 & 0.2 \\
\hline \multirow[t]{2}{*}{55} & Truck & 26,760 & 0.05 & 0 & 0.03 & 0.2 & 0 & 0.1 & 1 & 0 & 0.6 \\
\hline & Rail & 9,920 & 0.01 & 0 & 0.007 & 0.03 & 0 & 0.03 & 0.09 & 0 & 0.1 \\
\hline \multicolumn{12}{|c|}{ 630,000 Metric Tons of $U F_{4}$} \\
\hline \multirow[t]{2}{*}{30} & Truck & 36,025 & 0.07 & 0 & 0.04 & 0.3 & 0 & 0.2 & 1 & 0 & 0.8 \\
\hline & Rail & 13,100 & 0.03 & 0 & 0.01 & 0.05 & 0 & 0.04 & 0.2 & 0 & 0.2 \\
\hline \multirow[t]{2}{*}{55} & Truck & 33,700 & 0.06 & 0 & 0.04 & 0.2 & 0 & 0.2 & 0 & 0 & 0.8 \\
\hline & Rail & 12,500 & 0.02 & 0 & 0.009 & 0.03 & 0 & 0.04 & 0.1 & 0 & 0.2 \\
\hline
\end{tabular}

a Risks for rail transport were estimated on a railcar basis; therefore, the number of railcars was used for the total number of rail shipments.

b Radiological LCFs were estimated from the calculated doses by using dose-to-risk conversion factors of 0.0005 and 0.0004 fatality per person-rem for members of the general public and occupational workers, respectively, as recommended in ICRP Publication 60 (ICRP 1991). The approximate corresponding dose received for each radiological fatality risk listed in this table may be obtained by multiplying the fatality risk by 2,500 (i.e., $1 \div 0.0004$ ).

c Potential for irreversible adverse effects from chemical exposures. 
TABLE 8.2 Total Risks from Accidents during Shipment of $\mathbf{U F}_{4}$

\begin{tabular}{|c|c|c|c|c|c|c|c|c|c|c|c|}
\hline \multirow[b]{2}{*}{$\begin{array}{c}\text { Drum } \\
\text { Size } \\
\text { (gal) }\end{array}$} & \multirow[b]{2}{*}{ Mode } & \multirow[b]{2}{*}{$\begin{array}{c}\text { Total } \\
\text { Shipments }\end{array}$} & \multicolumn{3}{|c|}{ Risks over $250 \mathrm{~km}$} & \multicolumn{3}{|c|}{ Risks over $1,000 \mathrm{~km}$} & \multicolumn{3}{|c|}{ Risks over $5,000 \mathrm{~km}$} \\
\hline & & & $\begin{array}{c}\text { Radiological } \\
\text { LCF }^{b}\end{array}$ & $\begin{array}{c}\text { Chemical } \\
\text { Effects }\end{array}$ & $\begin{array}{c}\text { Vehicular } \\
\text { LCF }\end{array}$ & $\begin{array}{c}\text { Radiological } \\
\text { LCF }^{b}\end{array}$ & $\begin{array}{c}\text { Chemical } \\
\text { Effects }\end{array}$ & $\begin{array}{c}\text { Vehicular } \\
\text { LCF }\end{array}$ & $\begin{array}{c}\text { Radiological } \\
\text { LCF }^{\mathrm{b}}\end{array}$ & $\begin{array}{c}\text { Chemical } \\
\text { Effects }\end{array}$ & $\begin{array}{c}\text { Vehicular } \\
\text { LCF }\end{array}$ \\
\hline \multicolumn{12}{|c|}{ 500,000 Metric Tons of $U F_{4}$} \\
\hline \multirow[t]{2}{*}{30} & Truck & 28,620 & 0.0001 & 0.005 & 0.3 & 0.0004 & 0.02 & 1 & 0.002 & 0.1 & 6 \\
\hline & Rail & 10,480 & 0.00001 & 0.001 & 0.1 & 0.00005 & 0.005 & 0.5 & 0.0002 & 0.03 & 2 \\
\hline \multirow[t]{2}{*}{55} & Truck & 26,760 & 0.0001 & 0.006 & 0.3 & 0.0004 & 0.02 & 1 & 0.002 & 0.1 & 5 \\
\hline & Rail & 9,920 & 0.00001 & 0.001 & 0.1 & 0.00005 & 0.005 & 0.5 & 0.0002 & 0.03 & 2 \\
\hline \multicolumn{12}{|c|}{ 630,000 Metric Tons of $U F_{4}$} \\
\hline \multirow[t]{2}{*}{30} & Truck & 36,025 & 0.0001 & 0.007 & 0.4 & 0.0005 & 0.03 & 1 & 0.003 & 0.1 & 7 \\
\hline & Rail & 13,100 & 0.00001 & 0.002 & 0.2 & 0.00006 & 0.007 & 0.6 & 0.0003 & 0.03 & 3 \\
\hline \multirow[t]{2}{*}{55} & Truck & 33,700 & 0.0001 & 0.007 & 0.3 & 0.0005 & 0.03 & 1 & 0.003 & 0.1 & 7 \\
\hline & Rail & 12,500 & 0.00001 & 0.002 & 0.1 & 0.00006 & 0.007 & 0.6 & 0.0003 & 0.03 & 3 \\
\hline
\end{tabular}

a Risks for rail transport were estimated on a railcar basis; therefore, the number of railcars was used for the total number of rail shipments.

b Radiological LCFs were estimated from the calculated doses by using dose-to-risk conversion factors of 0.0005 and 0.0004 fatality per person-rem for members of the general public and occupational workers, respectively, as recommended in ICRP Publication 60 (ICRP 1991). The approximate corresponding dose received for each radiological fatality risk listed in this table may be obtained by multiplying the fatality risk by 2,500 (i.e., $1 \div 0.0004$ ).

c Potential for irreversible adverse effects from chemical exposures. 


\section{TABLE 8.3 Potential Consequences to the Population from Severe Accidents during Shipment of $\mathbf{U F}_{4}$}

\begin{tabular}{|c|c|c|c|c|c|c|c|c|}
\hline \multirow[b]{2}{*}{ Type of Risk } & \multirow{2}{*}{$\begin{array}{c}\text { Drum } \\
\text { Size } \\
\text { (gal) }\end{array}$} & \multirow[b]{2}{*}{ Mode } & \multicolumn{3}{|c|}{ Neutral Weather Conditions } & \multicolumn{3}{|c|}{ Stable Weather Conditions } \\
\hline & & & Rural & Suburban & Urban & Rural & Suburban & Urban \\
\hline \multirow{4}{*}{$\begin{array}{l}\text { Radiological } \\
\qquad(\mathrm{LCFs})^{\mathrm{a}}\end{array}$} & \multirow[t]{2}{*}{30} & Truck & 0.09 & 0.09 & 0.2 & 0.2 & 0.2 & 0.5 \\
\hline & & Rail & 0.3 & 0.2 & 0.5 & 0.6 & 0.6 & 1 \\
\hline & 55 & Truck & 0.1 & 0.1 & 0.2 & 0.2 & 0.2 & 0.5 \\
\hline & & Rail & 0.3 & 0.3 & 0.6 & 0.7 & 0.6 & 1 \\
\hline \multirow{4}{*}{$\begin{array}{l}\text { Chemical } \\
\text { (no. of persons) }\end{array}$} & \multirow[t]{2}{*}{30} & Truck & 0.15 & 18 & 40 & 0.94 & 110 & 250 \\
\hline & & Rail & 0.45 & 54 & 120 & 2.3 & 270 & 610 \\
\hline & \multirow[t]{2}{*}{55} & Truck & 0.16 & 20 & 44 & 1 & 120 & 270 \\
\hline & & Rail & 0.46 & 55 & 120 & 2.4 & 290 & 650 \\
\hline
\end{tabular}

a Radiological risks of latent cancer fatalities (LCFs) were estimated from the calculated doses by using doseto-risk conversion factors of 0.0005 and 0.0004 fatality per person-rem for members of the general public and occupational workers, respectively, as recommended in ICRP Publication 60 (ICRP 1991). The approximate corresponding dose received for each radiological fatality risk listed in this table may be obtained by multiplying the fatality risk by 2,500 (i.e., $1 \div 0.0004$ ).

b Chemical risks were measured as the number of persons with potential for irreversible adverse effects. Exposure to HF or uranium compounds was estimated to result in fatality for approximately $1 \%$ or less of those persons experiencing irreversible adverse effects (Policastro et al. 1997). Therefore, one fatality may be expected from chemical effects due to a severe accident involving a railcar in an urban environment under stable weather conditions. 
TABLE 8.4 Potential Consequences to the MEI from Severe Accidents during Shipment of $\mathbf{U F}_{4}$

\begin{tabular}{|c|c|c|c|c|c|}
\hline \multirow{3}{*}{$\begin{array}{c}\text { Drum } \\
\text { Size } \\
\text { (gal) }\end{array}$} & \multirow[b]{3}{*}{ Mode } & \multicolumn{4}{|c|}{ Accident Risk } \\
\hline & & \multicolumn{2}{|c|}{ Neutral Weather Conditions } & \multicolumn{2}{|c|}{ Stable Weather Conditions } \\
\hline & & $\begin{array}{l}\text { Radiological } \\
\text { Risk of LCF }\end{array}$ & $\begin{array}{l}\text { Chemical } \\
\text { Effects }\end{array}$ & $\begin{array}{l}\text { Radiological } \\
\text { Risk of LCF }\end{array}$ & $\begin{array}{l}\text { Chemical } \\
\text { Effects }\end{array}$ \\
\hline \multirow[t]{2}{*}{30} & Truck & 0.004 & Yes & 0.06 & Yes \\
\hline & Rail & 0.01 & Yes & 0.2 & Yes \\
\hline \multirow[t]{2}{*}{55} & Truck & 0.004 & Yes & 0.06 & Yes \\
\hline & Rail & 0.01 & Yes & 0.2 & Yes \\
\hline
\end{tabular}

a Lifetime risk of LCF for an individual was estimated from the calculated doses by using a dose-to-risk conversion factor of $5 \times 10^{-4}$ fatality per person-rem for members of the general public, as recommended in ICRP Publication 60 (ICRP 1991). The approximate corresponding dose received for each radiological fatality risk listed in this table may be obtained by multiplying the fatality risk by 2,000 (i.e., $1 \div 0.0005$ ).

b Yes or no applies to the effect of chemical exposure on the MEI. There is no probability estimate; either there would or would not be an irreversible adverse effect.

TABLE 8.5 Consequences to the MEI during Routine Shipment of UF

\begin{tabular}{lllllll}
\hline & & \multicolumn{5}{c}{ Routine Radiological Risk from Single Shipment } \\
(lifetime risk of LCF)
\end{tabular}

a Lifetime risk of LCF for an individual was estimated from the calculated dose by using the dose-to-risk conversion factor of 0.0005 fatality per person-rem for members of the general public, as recommended in ICRP Publication 60 (ICRP 1991). The corresponding dose received for each radiological fatality risk listed in this table may be obtained by multiplying the risk of LCF by 2,000 (i.e., $1 \div 0.0005$ ).

b $\mathrm{NA}=$ not applicable. 
Impacts from a potential severe accident could lead to fatalities from both radiological and chemical effects. Up to 1 potential LCF from radiological hazards is estimated for a rail accident occurring in an urban population zone under stable weather conditions. On the basis of chemical toxicity effects for the same conditions, up to 650 persons could be affected by irreversible adverse effects. Exposure to HF or uranium compounds was estimated to result in death to approximately $1 \%$ or less of those persons experiencing irreversible adverse effects (Policastro et al. 1997). Therefore, one fatality may be expected from chemical effects due to a severe accident involving a railcar in an urban environment under stable weather conditions. Note that the number of irreversible adverse effects is probably an overestimate, because the toxicity value for $\mathrm{UF}_{4}$, which is only slightly soluble, was not adjusted to account for lowered intake due to low solubility. Because of the lack of data on absorption of $\mathrm{UF}_{4}$, the toxicity value used essentially assumed the same uptake of $\mathrm{UF}_{4}$ as would occur for uranyl fluoride, a soluble compound. Details on the toxicity values and adjustments for solubility are given in Appendix C, Section C.5.2.1, of the depleted UF 6 PEIS (DOE 1999).

The highest potential routine radiological exposure to an MEI, with an LCF risk of $2 \times 10^{-7}$, would be for a person stopped in traffic near a shipment for $30 \mathrm{~min}$ at a distance of $3.3 \mathrm{ft}(1 \mathrm{~m})$. Such an exposure would be approximately 2.5 times less than the exposure a person receives from natural sources in the course of 1 day. 


\section{PARAMETRIC ANALYSIS}

The parametric analysis of the disposal options considered the environmental impacts of disposing of $25 \%$ and $50 \%$ of the 560,000 metric tons of depleted $\mathrm{UF}_{6}$ inventory as $\mathrm{UF}_{4}$, similar to the analyses conducted in Appendix K of the PEIS (DOE 1999). The intent of the parametric analysis was to show how the environmental impacts calculated for the $100 \%$ cases would be affected by reductions in facility size and throughput. "Throughput" is a general term that refers to the amount of material handled or processed by a facility in a year. To simplify the analysis, only a subset of the disposal options was analyzed in detail; namely, the mine disposal of either 30-gal or 55-gal drums. A subset of options was selected because the relationships among the options within each category could be determined from the detailed analyses conducted for the $100 \%$ cases. Therefore, the results for the options analyzed in detail were used to estimate the impacts for the other options by comparison with the $100 \%$ cases.

For this analysis, it was assumed that the uranium material would be actively placed into disposal units over a 20-year period (from 2009 through 2028). The assessment considered the environmental impacts that would occur during (1) construction of a disposal facility, (2) routine disposal facility operations, (3) potential disposal facility accidents, and (4) the post-closure phase, defined as 1,000 years in the future after the disposal facility had failed. The areas of impact and the methodologies used to evaluate the parametric cases were the same as those used to evaluate the $100 \%$ cases. The supporting engineering data for the $25 \%$ and $50 \%$ parametric cases are provided in the engineering analysis report (Folga and Kier 2001).

\subsection{HUMAN HEALTH — NORMAL OPERATIONS}

\subsubsection{Radiological Impacts}

The estimated radiological impacts (radiation doses and LCFs) from the normal operation of a full-scale (100\%) disposal facility are described in Sections 6 and 7. Similar impacts were calculated for the $50 \%$ and $25 \%$ disposal facilities for the parametric analysis. Radiological impacts were calculated for the operational phase (the phase during which material would be disposed of) and the post-closure phase (assumed to be 1,000 years in the future after the disposal facility failed).

\subsubsection{Operational Phase}

The radiological impacts estimated for the $100 \%, 50 \%$, and $25 \%$ cases during the operational phase are shown in Figures 9.1 to 9.4 for involved workers. The impacts have been 


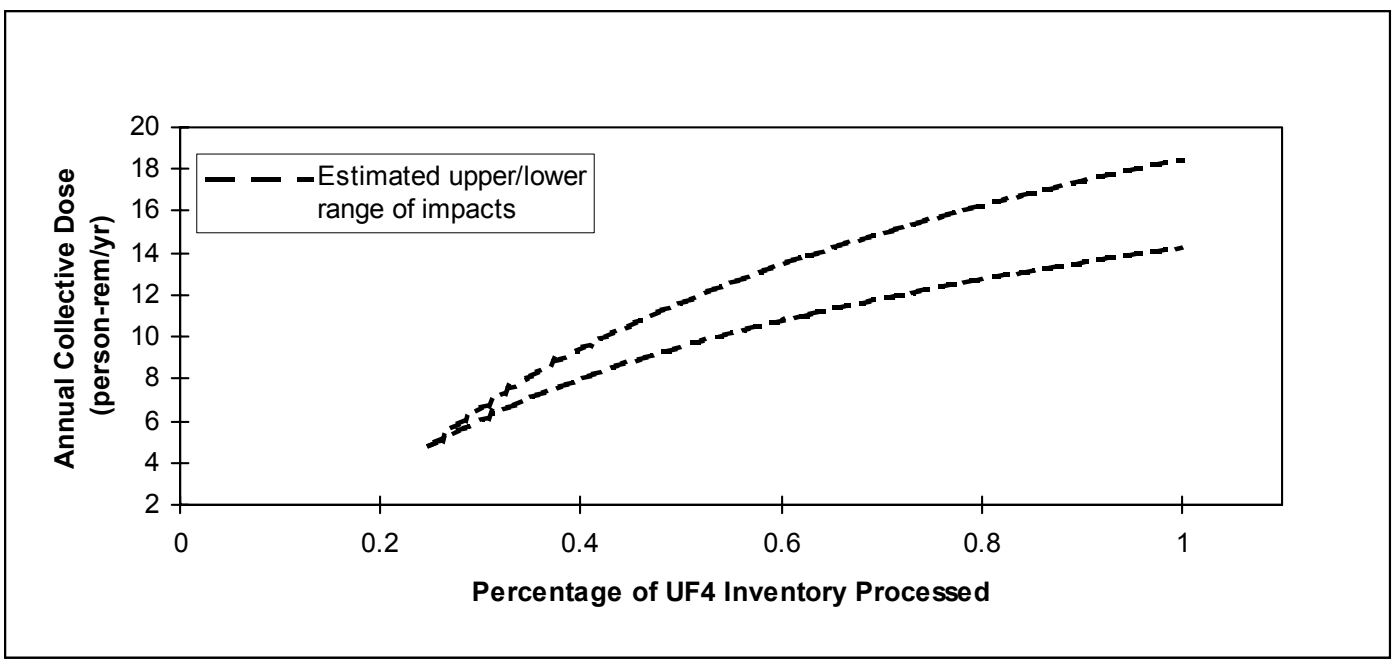

FIGURE 9.1 Estimated Annual Collective Dose to Involved Workers from the Disposal of 30-Gallon Drums (The ranges reflect differences in disposal technologies, i.e., shallow earthen structures, vaults, and mine.)

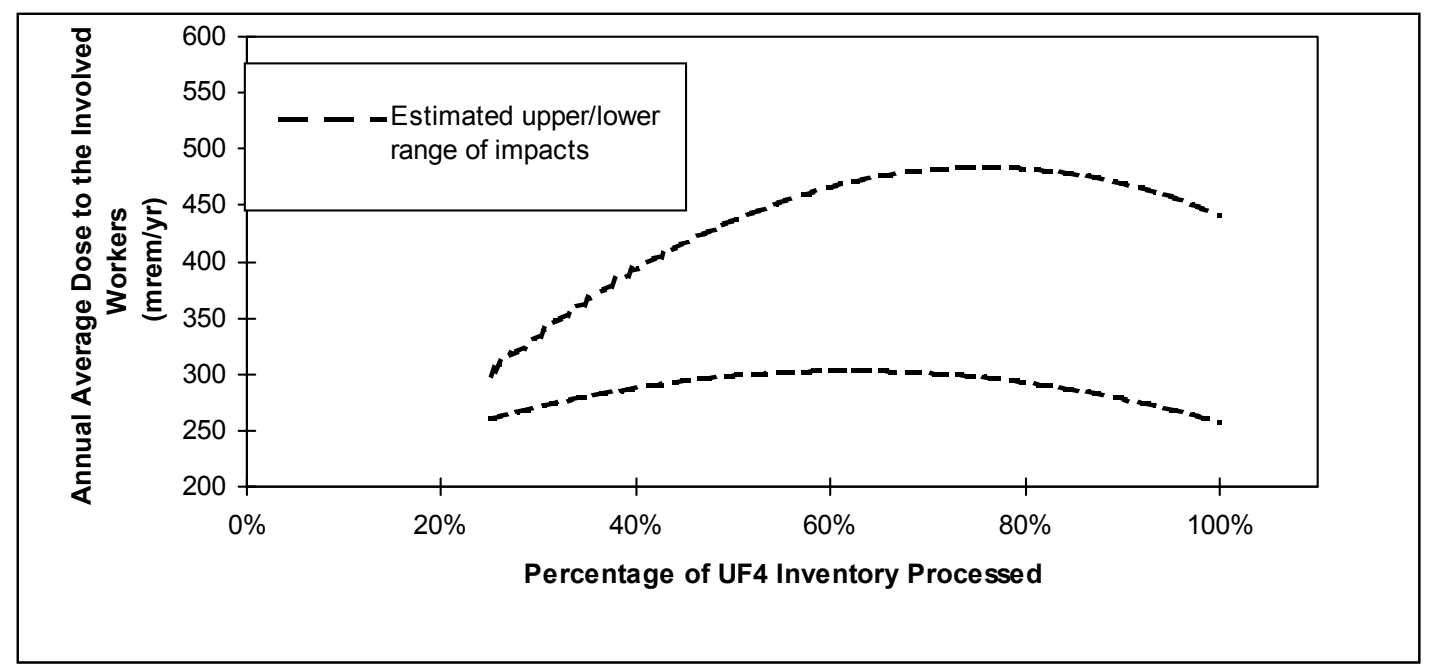

FIGURE 9.2 Estimated Annual Average Individual Dose to Involved Workers from the Disposal of 30-Gallon Drums (The ranges reflect differences in disposal technologies, i.e., shallow earthen structures, vaults, and mine.) 


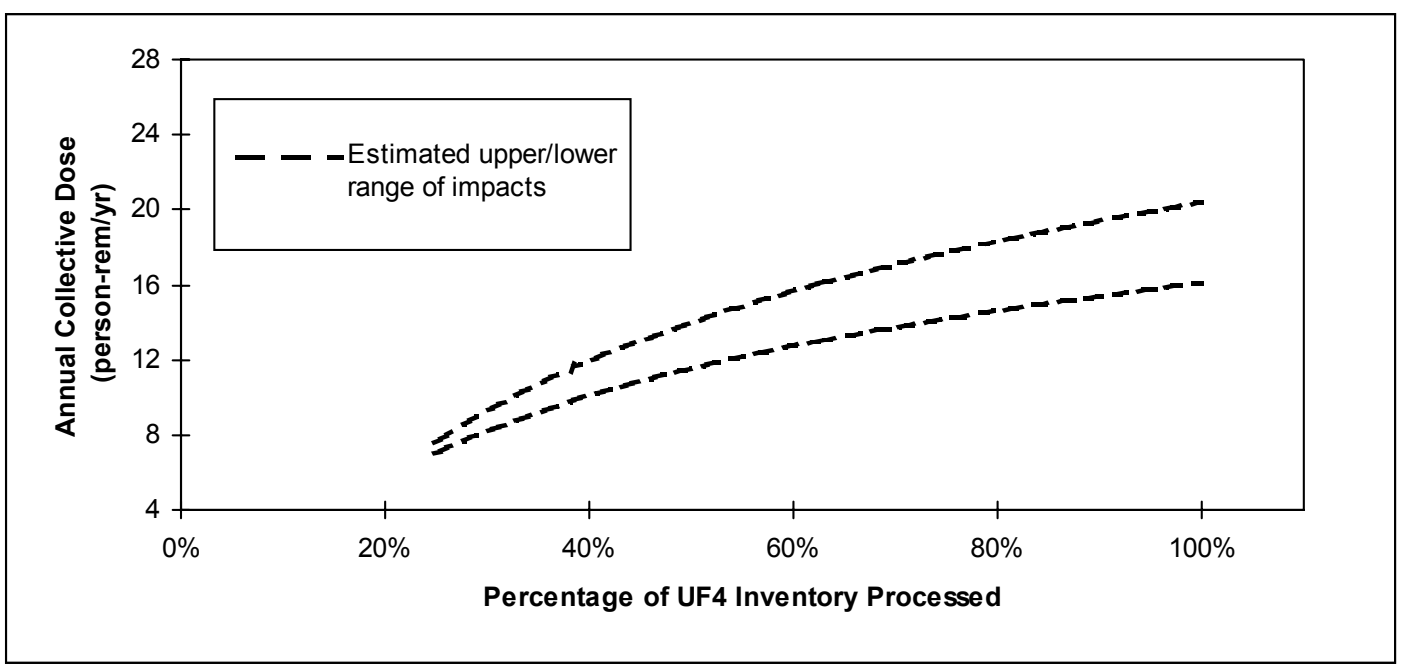

FIGURE 9.3 Estimated Annual Collective Dose to Involved Workers from the Disposal of 55-Gallon Drums (The ranges reflect differences in disposal technologies, i.e., shallow earthen structures, vaults, and mine.)

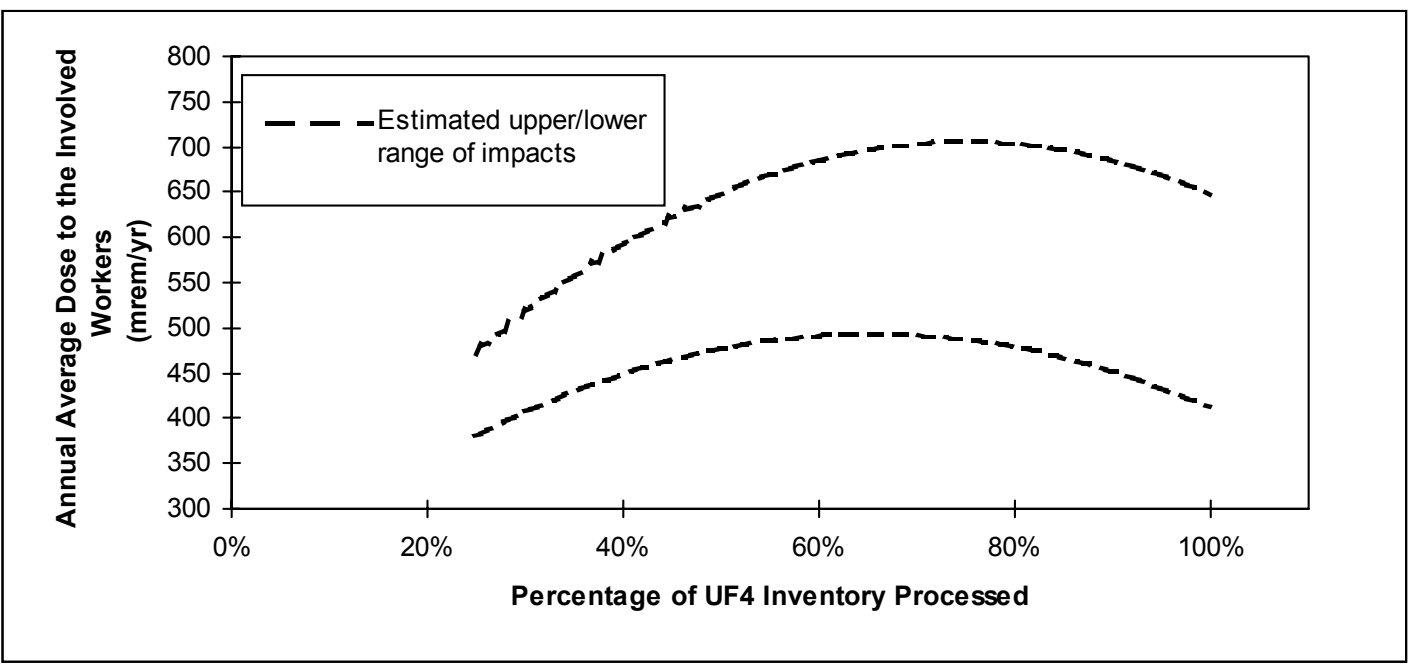

FIGURE 9.4 Estimated Annual Average Individual Dose to Involved Workers from the Disposal of 55-Gallon Drums (The ranges reflect differences in disposal technologies, i.e., shallow earthen structures, vaults, and mine.) 
presented for the disposal of both 30-gal and 55-gal drums as a function of the amount of material requiring disposal. The range of impacts resulting from technology differences are presented by dashed lines in the figures. The area enclosed by the dashed lines indicates the range of impacts expected for throughputs between $25 \%$ and $100 \%$, taking into account technology differences.

The disposal of $\mathrm{UF}_{4}$ would not result in any airborne or waterborne emissions during operations. Therefore, no impacts on the noninvolved workers and the general public would be expected.

In general, the results of the parametric analysis (as shown in Figures 9.1 through 9.4) indicate that the collective radiological impacts during the operational phase would decrease with the total quantity of depleted uranium disposed of. The impacts from the $25 \%$ and $50 \%$ cases would be smaller than those from the $100 \%$ case, although the decrease would not be proportional to the reduction in throughput (i.e., the impacts from the $50 \%$ case would be greater than half of the impacts from the $100 \%$ case). Overall, radiation doses from the disposal of 55-gal drums would be larger than those from disposal of 30-gal drums because of the greater dose rate associated with the larger containers. In some cases, the average individual worker dose might increase or decrease as the throughput increased, primarily because the number of workers required would not increase at the same rate as would the collective dose. The doses shown in the figures can be converted to the number (or risk) of LCFs by multiplying the doses (in rem or person-rem) by $0.0004 \mathrm{LCF} /$ personrem for workers.

\subsubsection{Post-Closure Phase}

At some time in the future after the closure of the disposal facility, impacts could occur to the public through the use of contaminated groundwater and from external radiation if the cover materials eroded away. In general, the complete erosion of the cover material, especially for a vault or mine, would not occur until thousands of years after the facility had been closed. Therefore, external radiation exposures would not be expected within the time frame considered (i.e., 1,000 years). Even if complete erosion occurred, the radiation exposure could be reduced by adding new cover material. Groundwater contamination would not be expected to occur until hundreds to thousands of years after the disposal facility had been closed. The estimated groundwater concentrations and associated uncertainty are discussed in Section 7.1. For assessment purposes, the MEI was assumed to live at the edge of the disposal site and to use groundwater for drinking, irrigating plant foods and fodder, and feeding livestock. The potential radiation doses from using contaminated groundwater were based on groundwater concentrations calculated in the groundwater analysis that is discussed in detail in Section 7.2.

The estimates of the radiological impacts during the post-closure phase for disposal of $100 \%$ of the inventory were very small (i.e., less than $3 \times 10^{-6} \mathrm{mrem} / \mathrm{yr}$ ) within 1,000 years of facility 
failure. Therefore, potential radiation exposures would be even smaller for the $25 \%$ and $50 \%$ parametric cases because a smaller inventory would be involved.

\subsubsection{Chemical Impacts}

\subsubsection{Operational Phase}

The estimated impacts from chemical exposures during the normal operation of full-scale $(100 \%)$ disposal facilities are described in Section 6.1.2. The results of the $100 \%$ case analyses for the operational phase indicated that noninvolved workers and members of the general public would receive essentially no exposures to chemicals from the disposal of $\mathrm{UF}_{4}$ because releases to the environment would be minimal. No adverse health impacts would be expected for any of the disposal facilities considered. Therefore, by comparison with the $100 \%$ case results, no adverse health impacts from chemical exposures would be expected for throughput rates between $25 \%$ and $100 \%$ for all disposal options.

\subsubsection{Post-Closure Phase}

As for radiological impacts, potential chemical impacts could occur to the general public at some time in the future through use of contaminated groundwater. The potential chemical impacts on an MEI from using contaminated groundwater were determined on the basis of the same assumptions discussed in Section 7.1.1 for radiological exposures. Chemical exposures were calculated for a time 1,000 years after the disposal facility was assumed to fail. Because of the low precipitation rate in a dry location, no chemical impacts would be expected within 1,000 years after failure for either the $25 \%$ or $50 \%$ parametric case.

\subsection{HUMAN HEALTH - ACCIDENT CONDITIONS}

\subsubsection{Radiological and Chemical Impacts}

The estimated accident impacts (radiation doses and LCFs) from potential accidents during operation of full-scale (100\%) disposal facilities are presented in Sections 6.2.1 and 6.2.2. The analysis of the $100 \%$ cases considered a range of accidents in four frequency categories; results are presented only for those accidents in each category that would have the greatest consequences (bounding accidents). Similar sets of accidents covering the same four frequency categories are 
defined in the engineering analysis report (Folga and Kier 2001) for the 25\% and 50\% throughput cases.

On the basis of the assessment of the $25 \%$ and $50 \%$ disposal cases, the accident impacts associated with each of the parametric cases would be the same as those presented for the $100 \%$ cases. The impacts would be identical because the bounding accidents producing the greatest consequences within each frequency category would be the same for the $100 \%, 50 \%$, and $25 \%$ cases.

The bounding accidents would be the same because they would involve only a limited amount of material that would be at risk under accident conditions regardless of the facility size or throughput. However, as a result of the reduced throughput rates, the actual frequencies of some accidents related to handling operations (i.e., the "mishandle/drop of drum" accident) would decrease as the number of containers being handled would decrease. The resulting risk of these accidents would also decrease as their frequencies would decrease. However, none of the accident frequencies would change enough to cause the accident to be placed in a different frequency category. Therefore, the overall impacts associated with the disposal options would be the same for all parametric cases.

\subsubsection{Physical Hazards}

The estimated health impacts, such as on-the-job injuries and fatalities, from potential physical accidents during the construction and operation of full-scale (100\%) disposal facilities are presented in Section 6.2.3. For the $100 \%$ analysis for mines, no on-the-job fatalities were estimated during construction and operation of a disposal facility for either 30-gal or 55-gal drums. The predicted number of on-the-job worker injuries for the 30 -gal $100 \%$ case was about 300 ; the number of injuries for the 55 -gal drum $100 \%$ case was estimated to be about 260 . The impacts of the $25 \%$ and $50 \%$ cases would be smaller than those for the $100 \%$ case, although the decrease would not be proportional to the reduction in throughput (i.e., the impacts for the $50 \%$ case would be greater than $50 \%$ of the impacts for the $100 \%$ case).

The predicted number of on-the-job worker fatalities over the duration of disposal operations for both the 30-gal and 55-gal drum options would be less than 1, ranging from 0.3 for the $25 \%$ case to 0.67 for the $100 \%$ case (including construction and operations). The predicted number of on-the-job injuries (including construction and operations) would range from 150 to 300. The number of injuries for the 30-gal drum option is shown as a function of throughput in Figure 9.5; the values for the 55-gal drum option are shown in Figure 9.6. 


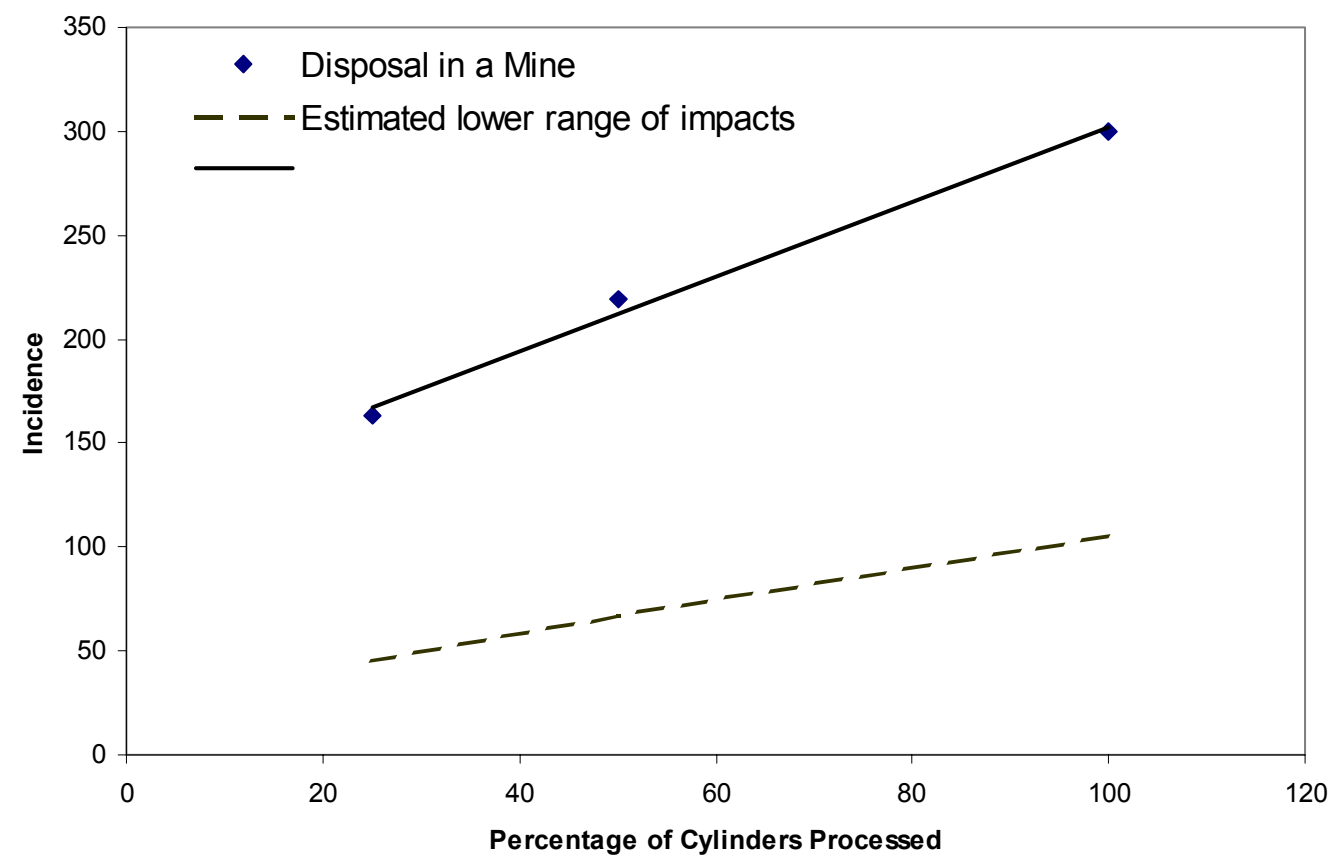

FIGURE 9.5 Estimated Number of on-the-Job Injuries (for entire construction and operational periods) from the Disposal of $\mathrm{UF}_{4}$ in 30-Gallon Drums (The ranges reflect differences in disposal technologies, i.e., shallow earthen structures, vaults, or mine.)

\subsection{AIR QUALITY}

The estimated impacts on air quality during construction and operation of full-scale disposal facilities are presented in detail in Section 6.3. For parametric analysis, only the construction and operation emissions for the wasteform facility and mine are considered. All of the pollutant emissions generated during disposal would be well below their respective air quality standards. As indicated in Section 6.3, during construction for mines, concentration increments of $\mathrm{PM}_{10}$ might be as high as $27 \%$ of the air quality standards. During operations for vaults, concentration increments of $\mathrm{NO}_{\mathrm{x}}$ would be less than $11 \%$ of the air quality standards.

The air quality impacts calculated for the $50 \%$ and $25 \%$ parametric cases, on the basis of the information provided in the engineering analysis report (Folga and Kier 2001), were found to be less than those for $100 \%$ cases. During construction, emissions for the $50 \%$ and $25 \%$ cases when compared with the $100 \%$ case would range from 43 to $64 \%$ and from 30 to $46 \%$, respectively. Resultant concentration increments would therefore be well below the standard. During operations, emissions for the $50 \%$ and $25 \%$ cases when compared with the $100 \%$ case would range from 42 to $79 \%$ and from 27 to $66 \%$, respectively. Accordingly, potential air quality impacts would be expected to be minor, as they would be for the case of the full-scale facility. 


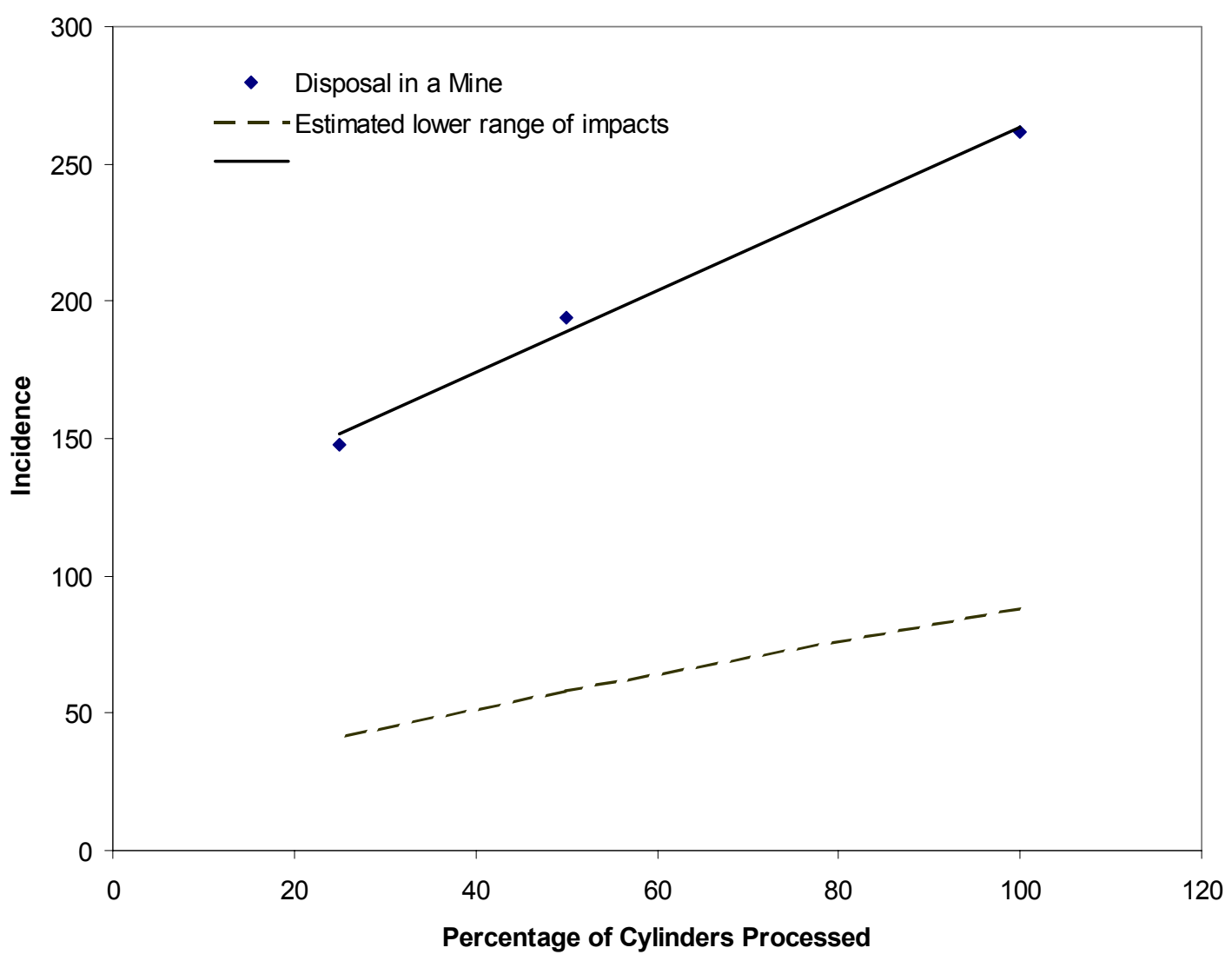

FIGURE 9.6 Estimated Number of on-the-Job Injuries (for entire construction and operational periods) from the Disposal of $\mathrm{UF}_{4}$ in 55-Gallon Drums (The ranges reflect differences in disposal technologies, i.e., shallow earthen structures, vaults, or mine.)

\subsection{WATER AND SOIL}

\subsubsection{Surface Water}

The estimated impacts on surface water during construction, operations, and potential accidents for full-scale (100\%) disposal facilities are discussed in Section 6.4. The actual impacts on surface water would depend on the ultimate site selected for disposal. However, for the generic sites considered, the impacts on surface water for the $100 \%$ case would be negligible for all disposal options for both the operational and post-closure phases. The impacts calculated for the $25 \%$ and $50 \%$ parametric cases, on the basis of information provided in the engineering analysis report (Folga and Kier 2001), would be less than those for the $100 \%$ case, and thus would also be negligible. 


\subsubsection{Groundwater}

The actual impacts on groundwater would depend on the ultimate site selected for disposal. However, during the operational phase, which would include construction and disposal activities, impacts on groundwater would be expected to be negligible. As described in Section 6.4, the impacts on groundwater from the $100 \%$ case would be expected to be negligible for the operational phase of all disposal options.

Impacts on groundwater during the post-closure phase are discussed in Section 7.3. Groundwater impacts during the post-closure phase would be limited to changes in quality caused by contamination migrating from the disposal facility hundreds to thousands of years in the future after failure of the engineered barriers. There would be no impacts on effective recharge, depth to groundwater, or flow direction once the facility was constructed.

If the disposal site was located in a dry environment, all of the resulting uranium concentrations in groundwater would be very low for at least 1,000 years in the future for disposal of $25 \%, 50 \%$, and $100 \%$ of the uranium material. Uranium concentrations would be well below the EPA proposed maximum contaminant level of $20: \mathrm{g} / \mathrm{L}$ (EPA 1996) used as a guideline in the PEIS.

\subsubsection{Soil}

The estimated impacts on soil during construction, operations, and potential accidents for full-scale (100\%) disposal facilities are presented in Section 6.4. The potential impacts evaluated included changes in topography (land elevation), permeability (ability to let water enter the ground), quality, and erosion potential for a dry location.

The impacts on soil from the $100 \%$ cases would be potentially moderate to large, but temporary, for the disposal options. These impacts would result from material excavated during disposal facility construction that would be left on site. For example, construction of a mine would require excavating a large amount of consolidated material. In the short term, this amount of material would cause changes in site topography. In the long term, contouring and reseeding would return soil conditions to their former state, and the impacts would be minor. The impacts calculated for the $25 \%$ and $50 \%$ parametric cases, on the basis of information provided in the engineering analysis report (Folga and Kier 2001), were also found to have potentially large, but temporary, impacts on soil, similar to the $100 \%$ cases. In the long term, impacts on soil would be minor for all disposal options. 


\subsection{SOCIOECONOMICS}

Construction of a 50\%-size wasteform facility for disposal in 30-gal containers would create 50 direct jobs and \$2.1 million in direct income (Table 9.1). Disposal in 55-gal containers would create 40 direct jobs and $\$ 1.5$ million in direct income. Operation of the wasteform facility would create 30 direct jobs and produce $\$ 1.5$ million in direct income if 30 -gal containers were used, and 30 direct jobs and $\$ 1.3$ million if 55-gal containers were used. For the $25 \%$ facility, construction of the wasteform facility would create 30 direct jobs and $\$ 1.2$ million in direct income if 30 -gal containers were used. Disposal in 55-gal containers would create 30 direct jobs and $\$ 1.1$ million in direct income. Operation of the wasteform facility would create 20 direct jobs and produce $\$ 1.1$ million in direct income if 30-gal containers were used, and 20 direct jobs and \$1.0 million if 55-gal containers were used.

\section{TABLE 9.1 Socioeconomic Impacts from $\mathrm{UF}_{4}$ Disposal Options: Parametric Analysis}

\begin{tabular}{|c|c|c|c|c|c|c|c|c|c|}
\hline \multirow{3}{*}{\multicolumn{2}{|c|}{$\begin{array}{l}\mathrm{UF}_{4} \text { Disposal Option and } \\
\text { Socioeconomic Parameter }\end{array}$}} & \multicolumn{4}{|c|}{$\begin{array}{c}50 \% \text { Case per Activity } \\
\text { and Drum Size }\end{array}$} & \multicolumn{4}{|c|}{$\begin{array}{c}25 \% \text { Case per Activity } \\
\text { and Drum Size }\end{array}$} \\
\hline & & \multicolumn{2}{|c|}{ Construction $^{\mathrm{a}}$} & \multicolumn{2}{|c|}{ Operations $^{\mathrm{b}}$} & \multicolumn{2}{|c|}{ Construction $^{\mathrm{a}}$} & \multicolumn{2}{|c|}{ Operations $^{\mathrm{b}}$} \\
\hline & & 30-gal & 55-gal & 30-gal & 55-gal & 30-gal & 55-gal & 30-gal & 55-gal \\
\hline \multicolumn{10}{|c|}{ Wasteform facility } \\
\hline & $\begin{array}{l}\text { Direct employment } \\
\text { (no. of persons) }\end{array}$ & 50 & 40 & 30 & 30 & 30 & 30 & 20 & 20 \\
\hline & $\begin{array}{l}\text { Direct income } \\
\quad(10 \text { year } 2000 \$)\end{array}$ & 2.1 & 1.5 & 1.5 & 1.3 & 1.2 & 1.1 & 1.1 & 1.0 \\
\hline \multicolumn{10}{|c|}{ Mine } \\
\hline & $\begin{array}{l}\text { Direct employment } \\
\text { (no. of persons) }\end{array}$ & 580 & 520 & 20 & 20 & 440 & 400 & 10 & 10 \\
\hline & $\begin{array}{l}\text { Direct income } \\
\quad(10 \text { year } 2000 \$)\end{array}$ & 19.4 & 17.4 & 1.1 & 1.0 & 14.8 & 13.4 & 0.8 & 0.7 \\
\hline \multicolumn{10}{|c|}{$\begin{array}{l}\text { Impacts in the peak year of construction: Year } 3 \text { for the wasteform facility, Year } 5 \text { or } 6 \text { for the mine. Construction impacts } \\
\text { from the shallow earthen structure and vault are identical in each year of the life of the facility, with construction } \\
\text { continuing concurrently with waste placement. }\end{array}$} \\
\hline \multicolumn{10}{|c|}{ Impacts are for the first year of operation. } \\
\hline \multicolumn{10}{|c|}{$\begin{array}{l}\text { For operations, direct employment includes those persons directly associated with operations, such as chemical operators, } \\
\text { foremen, and technicians, plus their line supervision. Clerical and health physics support is also included. The values } \\
\text { presented here represent the estimated number of workers for a "greenfield" site, where a new disposal facility would be } \\
\text { constructed in support of depleted } \mathrm{UF}_{4} \text { disposal. The number of additional workers that would be required at an already } \\
\text { existing disposal site would, in general, be less than those shown above. }\end{array}$} \\
\hline
\end{tabular}


Construction of a 50\%-size mined cavity for disposal in 30-gal containers would create 580 direct jobs and $\$ 19.4$ million in direct income. Disposal in 55-gal containers would create 520 direct jobs and $\$ 17.4$ million in direct income. Operation of the mined cavity would create 20 direct jobs and produce $\$ 1.1$ million in direct income if 30 -gal containers were used, and 20 direct jobs and $\$ 1.0$ million if 55-gal containers were used. For a $25 \%$ facility, construction of the mined cavity would create 440 direct jobs and $\$ 14.8$ million in direct income if 30 -gal containers were used, and 400 direct jobs and \$13.4 million in direct income if 55-gal containers were used. Operation of the mined cavity would create 10 direct jobs and produce $\$ 0.8$ million in direct income if 30-gal containers were used, and 10 direct jobs and $\$ 0.7$ million if 55-gal containers were used.

\subsection{ECOLOGY}

Site preparation for the construction of a facility for the disposal of $\mathrm{UF}_{4}$ would result in the disturbance of biotic communities, including the permanent replacement of habitat with structures

and paved areas. Existing vegetation would be destroyed during land-clearing activities. Wildlife would be disturbed by land clearing, noise, and human presence.

This disposal option would result in elevation of the soil surface and a reduction in soil permeability. The excavated material would primarily consist of rock removed from the drifts and ramps. The consequent decrease in surface soil moisture would make reestablishment of vegetation difficult and delay the establishment of native plant communities. Construction of a disposal facility for $\mathrm{UF}_{4}$ in a mine could result in a large adverse impact on existing vegetation and wildlife.

Impacts on wetlands and state and federally protected species due to facility construction would depend on facility location. Avoidance of wetland areas would be part of facility planning. Site-specific surveys for protected species would be conducted before finalization of facility siting plans. Impacts on air, surface water, groundwater, and soil quality during construction would be expected to be negligible for the $25 \%, 50 \%$, and $100 \%$ cases. Resulting construction-derived impacts on ecological resources would also be expected to be negligible. Impacts on ecological resources from air and water emissions would also be negligible during the operational phase of the disposal options.

During the post-closure phase, failure of facility integrity could result in contamination of groundwater. Groundwater could discharge to the surface (such as in wetland areas), thus exposing biota to contaminants. For the $100 \%$ cases, groundwater concentrations of uranium calculated for 1,000 years after failure of a mined facility would be well below levels expected to cause adverse impacts on aquatic biota. Groundwater uranium concentrations for the $25 \%$ and $50 \%$ cases would be lower, and resulting impacts on aquatic biota, therefore, would be negligible. 


\subsection{WASTE MANAGEMENT}

The estimated impacts from waste management operations during the construction and operation of full-scale (100\%) disposal facilities are discussed in detail in Section 6.7. The impacts on national waste management operations from construction of disposal facilities were found to be negligible for the $100 \%$ throughput case. The impacts that would result from construction and operation for the $25 \%$ and $50 \%$ parametric cases, on the basis of information provided in the engineering analysis report (Folga and Kier 2001), would be less than those for the $100 \%$ case, and thus would also be negligible.

\subsection{RESOURCE REQUIREMENTS}

The estimated impacts from resource requirements during construction and operation of full-scale (100\%) disposal facilities are presented in detail in Section 6.8. The impacts on resources, except for electrical consumption for a mine disposal facility, would be expected to be small for the $100 \%$ capacity case. Resource requirements for the $25 \%$ and $50 \%$ parametric cases considered would be less than those for the $100 \%$ case (Folga and Kier 2001).

Construction and operation of the disposal facilities would consume an irretrievable amount of electricity, fuel, concrete, steel and other metals, water, and miscellaneous chemicals. The total quantities of commonly used materials would not be expected to be significant. The requirements for disposal facility operations would generally not be resource-intensive, and the resources required are not considered rare or unique.

Furthermore, committing any of these resources (except for electrical consumption) would not be expected to cause a negative impact on the availability of these resources within local areas or nationally for the $100 \%, 50 \%$, and $25 \%$ cases. The magnitude of the impact from the large electricity requirement for a mine disposal facility on local energy resource usage would depend on the extent of existing site infrastructure.

\subsection{LAND USE}

Impacts from on-site disposal of excavated material during the construction and operation of a mine disposal facility would be expected to be moderate to large. Impacts on traffic volume would be associated with the construction labor force. On-site topographical modifications associated with disposition of the excavated material could potentially affect future on-site land use, although such impacts would be small. 
By comparison with the parametric analysis for disposal in mines, land use impacts from disposal in a shallow earthen structure or vault would be expected to range from negligible to moderate. Impacts on land use outside the boundaries of a disposal facility would consist of temporary traffic impacts associated with project construction. The actual impacts would depend on the specific site chosen.

\subsection{TRANSPORTATION}

The estimated risks from the shipment of all the $\mathrm{UF}_{4}$ from a conversion facility to a disposal site are presented in Section 8. The parametric risks for the $\mathrm{UF}_{4}$ shipments are presented in Figures 9.7 and 9.8 for shipment by truck and rail, respectively. The radiological risks from accidents are not presented because these risks would be at least 50 times less than the other estimated risks. 


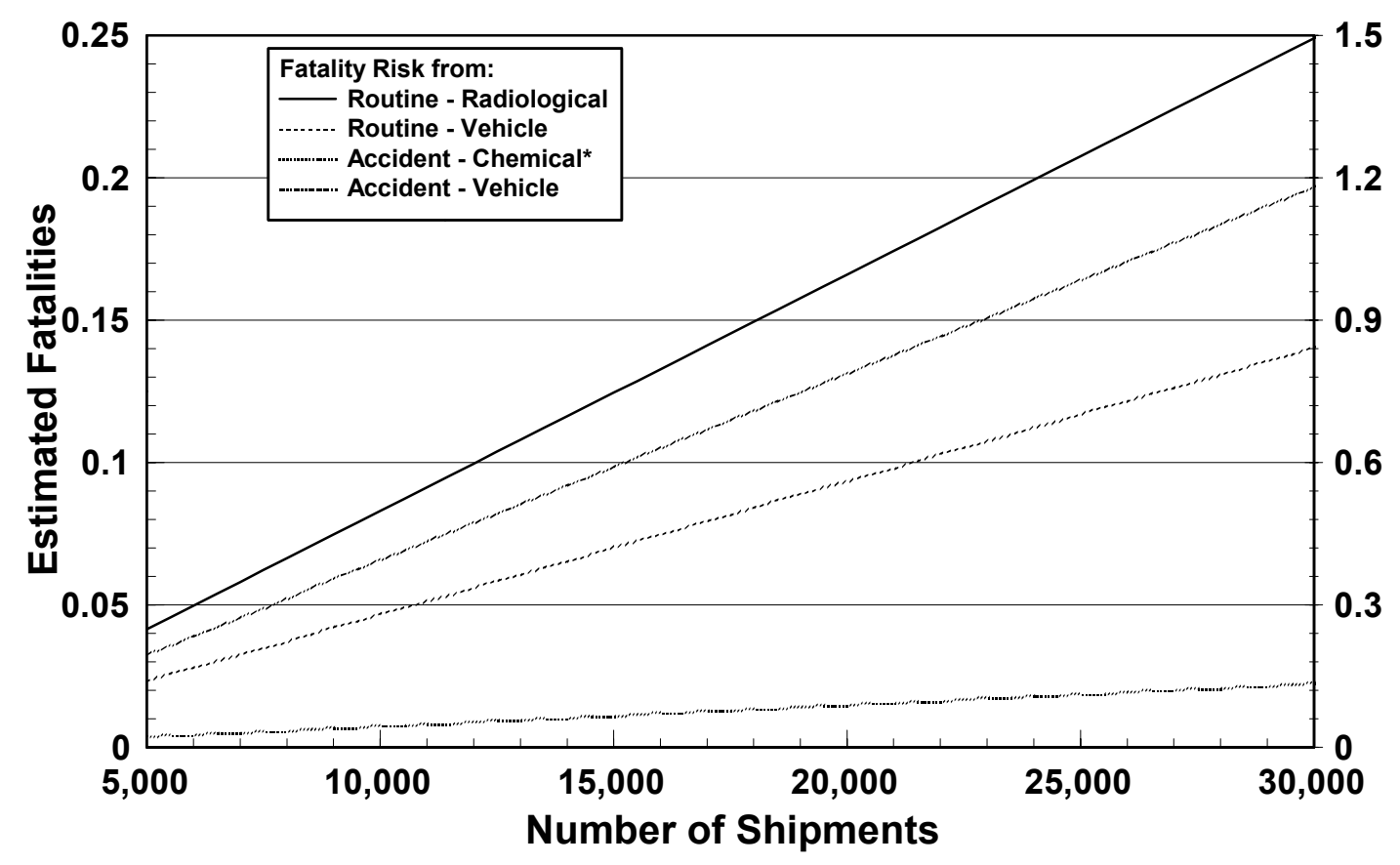

FIGURE 9.7 Estimated Truck Transportation Risks from Shipping UF $_{4}$ from the Conversion Facility to Disposal

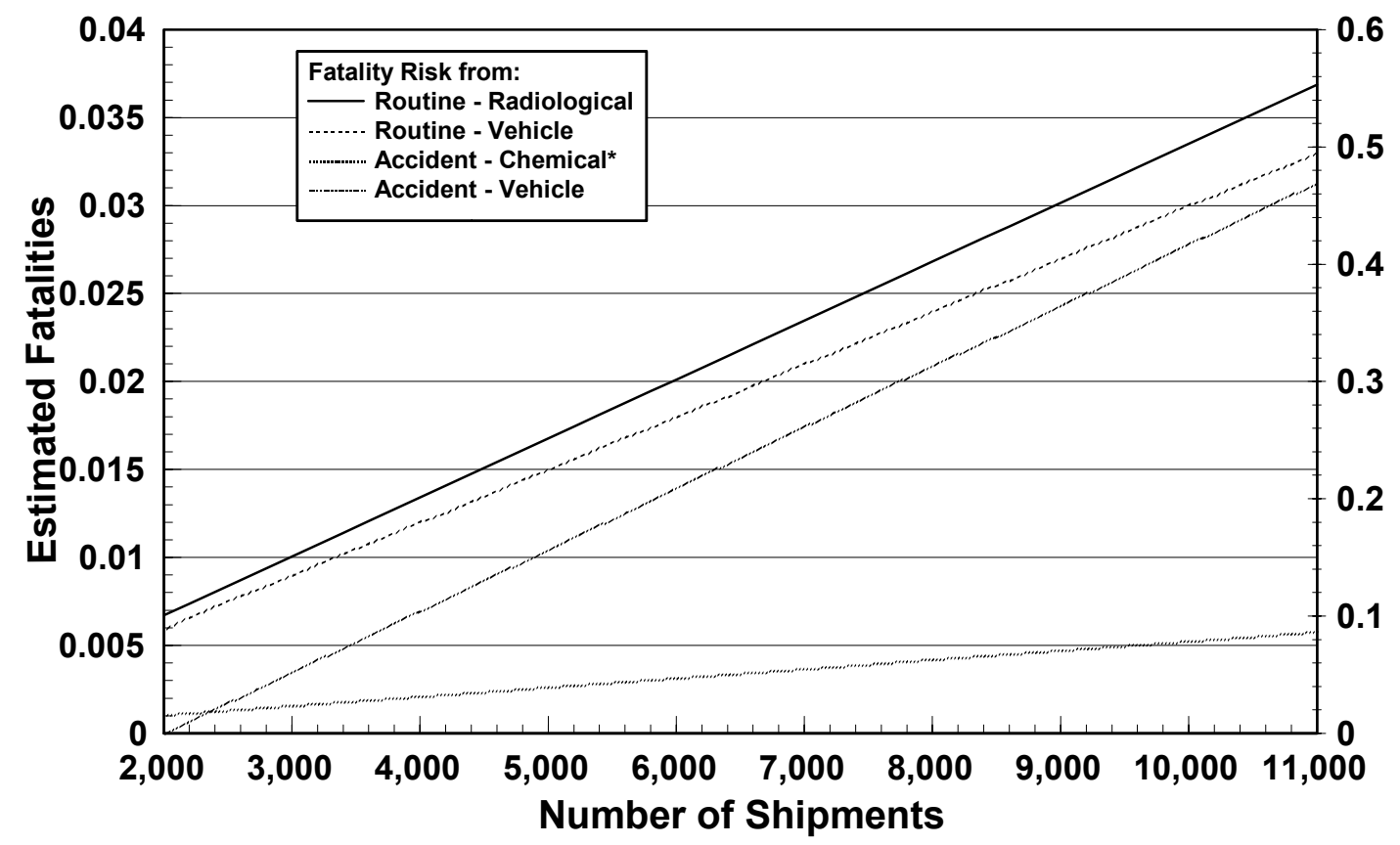

FIGURE 9.8 Estimated Rail Transportation Risks from Shipping UF $_{4}$ from the Conversion Facility to Disposal 


\section{REFERENCES}

Cheng, J.-J., et al., 1997, Human Health Impact Analyses for Normal Operations in Support of the Depleted Uranium Hexafluoride Programmatic Environmental Impact Statement, attachment to memorandum from Cheng (Argonne National Laboratory, Argonne, Ill.) to H.I. Avci (Argonne National Laboratory, Argonne, Ill.), May 21.

Croff, A.G., et al., 2000, Assessment of Preferred Depleted Uranium Disposal Forms, ORNL/TM2000/161, Oak Ridge National Laboratory, Oak Ridge, Tenn., June.

DOE: see U.S. Department of Energy.

EPA: see U.S. Environmental Protection Agency.

Folga, S., and P. Kier, 2001, Engineering Analysis for Disposal of Depleted Uranium Tetrafluoride $\left(U F_{4}\right)$, ANL/EAD/TM-106, Argonne National Laboratory, Argonne, Ill., June.

ICRP: see International Commission on Radiological Protection.

International Commission on Radiological Protection, 1991, 1990 Recommendations of the International Commission on Radiological Protection, ICRP Publication 60, Pergamon Press, Oxford, United Kingdom.

Katz, J.J., et al., 1986, The Chemistry of Actinide Elements, Vol. 2, 2nd ed., Chapman and Hall, New York, N.Y.

Lawrence Livermore National Laboratory, 1997, Depleted Uranium Hexafluoride Management Program; the Engineering Analysis Report for the Long-Term Management of Depleted Uranium Hexafluoride, UCRL-AR-124080, Volumes I and II, prepared by Lawrence Livermore National Laboratory, Science Applications International Corporation, Bechtel, and Lockheed Martin Energy Systems for U.S. Department of Energy.

LLNL: see Lawrence Livermore National Laboratory.

Martin Marietta Energy Systems, 1990, The Ultimate Disposal of Depleted Uranium, K/ETO-44, Oak Ridge, Tenn.

MMES: see Martin Marietta Energy Systems.

National Safety Council, 1995, Accident Facts, 1995 Edition, Itasca, Ill. 
National Safety Council, 1999, Injury Facts, 1999 Edition, Itasca, Ill.

NRC: see U.S. Nuclear Regulatory Commission.

Policastro, A.J., et al., 1997, Facility Accident Impact Analyses in Support of the Depleted Uranium Hexafluoride Programmatic Environmental Impact Statement, attachment to memorandum from Policastro (Argonne National Laboratory, Argonne, Ill.) to H.I. Avci (Argonne National Laboratory, Argonne, Ill.), June 15.

Tomasko, D., 2001, unpublished information on groundwater calculations for disposal of $\mathrm{UF}_{4}$, Argonne National Laboratory, Argonne, Ill., July.

Tschanz, J., 1997, Air Impact Analyses in Support of the Depleted Uranium Hexafluoride Programmatic Environmental Impact Statement, attachment to memorandum from Tschanz (Argonne National Laboratory, Argonne, Ill.) to H.I. Avci (Argonne National Laboratory, Argonne, Ill.), May 21.

U.S. Department of Energy, 1992, Radiological Control Manual, DOE/EH-0256T, Assistant Secretary for Environment, Safety and Health, Washington, D.C., June.

U.S. Department of Energy, 1996, The 1996 Baseline Environmental Management Report, DOE/EM-0290, Washington, D.C., June.

U.S. Department of Energy, 1997, Final Waste Management Programmatic Environmental Impact Statement for Managing Treatment, Storage, and Disposal of Radioactive and Hazardous Waste, DOE/EIS-0200-F, Office of Environmental Management, Washington, D.C., May.

U.S. Department of Energy, 1999, Programmatic Environmental Impact Statement for Alternative Strategies for the Long-Term Management and Use of Depleted Uranium Hexafluoride, DOE/EIS-0269, Office of Nuclear Energy, Science and Technology, Germantown, Md., Apr.

U.S. Environmental Protection Agency, 1996, Drinking Water Regulations and Health Advisories, EPA 882-B-96-002, Office of Water, Washington, D.C., Oct., pp. 1-11.

U.S. Nuclear Regulatory Commission, 1994a, Final Environmental Impact Statement for the Construction and Operation of Claiborne Enrichment Center, Homer, Louisiana, Docket No. 70-3070, NUREG-1484, Vols. 1 and 2, Office of Nuclear Material Safety and Safeguards, Washington, D.C.

U.S. Nuclear Regulatory Commission, 1994b, "10 CFR Part 19, et al., Certification of Gaseous Diffusion Plants; Final Rule," discussion on Section 76.85, "Assessment of Accidents," Federal Register 59(184):48954-49855, Sept. 23. 